Österreichische Akademie der Wissenschaften / Austrian Academy of Sciences AAS WORKING PAPERS IN SOCIAL ANTHROPOLOGY

Volume 32

Daniel Martin Varisco

THE STATE OF AGRICULTURE

IN THE MUTAWAKKILITE KINGDOM

OF YEMEN, 1918-1962:

A DOCUMENTARY OVERVIEW

Iriveluth

Band 32

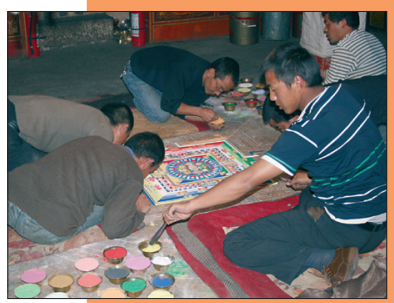




\section{AAS Working Papers in Social Anthropology / \\ ÖAW Arbeitspapiere zur Sozialanthropologie}

ISBN-Online: 978-3-7001-8256-6

DOI: $10.1553 /$ wpsa32

Wien 2018

Editors / Herausgeber:

Andre Gingrich \& Guntram Hazod

(C) Institut für Sozialanthropologie

Österreichische Akademie der Wissenschaften

Hollandstraße 11-13

A-1020 Wien

Fax: 01/ 51581-6450

E-Mail: sozialanthropologie@oeaw.ac.at 


\title{
THE STATE OF AGRICULTURE IN THE MUTAWAKKILITE KINGDOM OF YEMEN, 1918-1962: A DOCUMENTARY OVERVIEW
}

\author{
DANIEL MARTIN VARISCO
}

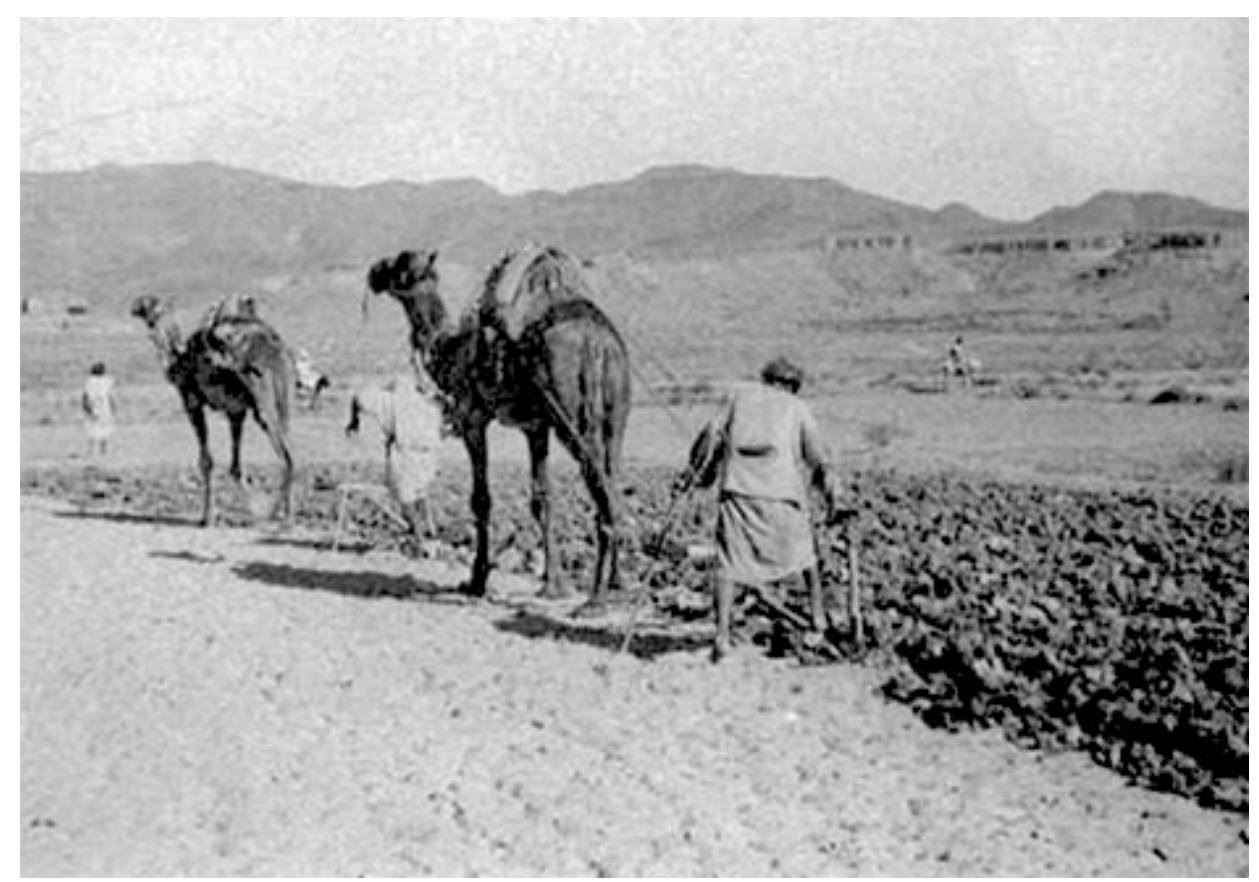

Traditional plow pulled by camel near Șan'ā', photography by Rossi in the late 1930s.

\begin{abstract}
Yemen has a rich tradition of agriculture, stemming from the South Arabian kingdoms through the Islamic era. In the 10th century the Yemeni savant al-Ḥasan al-Hamdānī referred to his homeland as alYaman al-khadrā' (the verdant Yemen) due to its agricultural wealth. Several important treatises and almanacs exist from the Rasulid era (13th-15th centuries). Yemeni scholars, anthropologists and agricultural experts have written about Yemen's agriculture in the past half century, but less is known about the state of agriculture during the Mutawakkilite Kingdom of Imams Yahyā and Ahmad during the $20^{\text {th }}$ century. This study draws on Arabic sources, foreign travelers and the report of a 1955 FAO mission to Yemen in describing the role of agriculture and cultivated crops in the area ruled by the two imams between 1918 and 1962. The information in these sources is here made available in English.
\end{abstract}

\section{Note}

The author expresses his appreciation to the Institute for Social Anthropology of the Austrian Academy of Sciences for a postdoctoral scholarship in 2017-2018, during which time this monograph was written. I thank Prof. Andre Gingrich, his colleagues and staff for their support. 


\section{Contents}

Introduction

1 'Abd al-Wāsi' ibn Yahyāa al-Wāsi'ī. Ta'rīkh al-Yaman Cairo: Maṭa'at Hijāzī, 1366/1948

2 Muḥammad ibn 'Alī al-Akwa'. Șaḥfat min ta'rīkh al-Yemen al-ijtimā' '̄ wa-qișat hayātī. Damascus: Maṭba'at al-Kātib al-‘Arab̄i, 1979

3 Nazīh Mu'ayyid al-'Aẓm. Riḥla fì bilād al-'Arabiyya al-Sa 'ūdiyya.

Second Edition. Cairo: Sharikat Dār al-Tanwīr li-al-Tibā‘a wa-al-Nashr, 1986.

Original, 1937

4 Ettore Rossi. "Note sull'irrigazione, l'agricoltura e le stagioni nel Yemen." Oriento Moderno 33(8-9): 349-361, 1953

5 Muhammad Ḥaydara. Takwīm. Ta 'izz, 1945 [Translated by Serjeant (1954)] 32

6 Nello Lambardi. Divisioni Amministrative del Yemen con Notizie Economiche e Demogra-fiche. Oriente Moderno 27(7/9): 143-162, 1947 36

7 FAO. Report of the FAO Mission to Yemen. Rome: FAO, 1960 42

8 Ḥusayn ibn 'Alī al-Waysī. al-Yaman al-Kubrā. Cairo: Maṭba'at al-Nahḍa al-'Arabiyya, 1962 Overview of Agriculture in Mutawakkilite Yemen 49

Appendix A. Cultivated Crops of Mutawakkilite Yemen 62

Bibliography 68 


\section{Introduction}

At the start of the 20th century most of Yemen was under the nominal control of the Ottoman Empire, which was never able to effectively control the highlands and was forced to allow the Zaydī imams to remain as local power brokers. ${ }^{1}$ In the southern part of Yemen, centered on Aden and Hadramawt, the British had been in nominal control since 1839. With the onset of World War I in 1913, the Zaydī imams gained de facto control in most of the highlands, and with the fall of the Ottomans in 1918 Imam Yahyā established absolute rule, declaring the Mutawakkilite kingdom. Yahyā struggled at first with the Idrisis in the 'Asīr region for control of the northern Tihāma, including the port of al-Hudayda. In 1934 King Sa'ūd took control of the 'Asīr region and Najrān. His forces unsuccessfully invaded Yahyā's Yemen, culminating in the Treaty of Tầ'if in which Yemen ceded control of the annexed areas for a limited time period. Imam Yahyā was assassinated in February, 1948, and shortly thereafter his son Ahmad became the ruler. Although there were diplomatic delegations from Britain, Italy and the Soviets, the kingdom was virtually closed to foreigners. With the death of Ahmad in 1962, a revolution brought the Yemen Arab Republic into existence. Supported by Egypt's President Nasser, the young republic was engaged in a civil war with the Saudi-backed imamate successor, Imam Badr, until 1970.

The coastal region of the Tihāma along the Red Sea and the southern coast in the Gulf of Aden were frequently overrun by foreign invaders, but the highlands were isolated from most political currents in the region due to its geographical barriers and the power of local tribes. The Zaydī imams, who first came to Yemen in the late 9th century, ruled by forming alliances with tribes rather than forming a strong central state. At the end of the Mutawakkilite kingdom there were seven recognised provinces (liwā', sg.): Ta'izz, Ibb, al-Bayḍā', Șan 'ā', Hajja, Șa 'da, al-Hudayda, basically following the divisions during the Turkish period. ${ }^{2}$ Although 'Asīr and Najrān were under the control of of Saudi Arabia after 1934, the Yemeni historian al-Waysī included them in "Greater Yemen" (al-Yaman $a l-k u b r \bar{a}){ }^{3}$. The British held power, nominal outside Aden for the most part, in the Aden Protectorate and Hadramawt. For several centuries there had been major Hadramī emigration to Southeast Asia and the east coast of Africa with continuing family and economic links. In 1967 a revolution in the south threw out the British and created the Peoples' Democratic Republic of Yemen (PDRY), which in 1990 was united with the Yemen Arab Republic (YAR) in the north to become the Republic of Yemen (ROY). ${ }^{4}$

\footnotetext{
${ }^{1}$ As noted by a British diplomat in Aden, "The Turkish suzerainty in the Yemen, during its final phase from 1878 to 1918, bred blight and decay" (Jacob 1932: 136). Writing in a 1923 dispatch to the U.S. Consul in Aden, Ameen Rihani commented: "The Turks did little or nothing to change or improve conditions. They planted hasheesh, and brought dancing girls, and spent a little money and used to get drunk that's all the natives remember about them. The stagnation, religious and moral and political, is appalling" (Sinclair 1976: 97).

${ }^{2}$ Al-Waysī (1962: 18). Imam Yahyā had earlier divided Yemen four divisions, each under control of one of his sons (Naval Intelligence Division 1946: 331, 332, 357). As of 1946 it is reported that no Western traveler had visited Sa'da (Naval Intelligence Division 1946: 575).

${ }^{3}$ Al-Waysī (1962:117). This included al-Mikhlāf al-Sulaymāniya and Liwā' Jīzān. An official Yemeni publication in 1360/1941 divided Yemen into three parts: the independent part of the Mutawakkilite Kingdom, the area under control of the British and 'Asīr subject to the Saudi regime (Lambardi 1947: 143 , note 1$)$.

${ }^{4}$ For a concise history of modern Yemen during the 20th century, see Dresch (2000).
} 
The population in Yemen in 1900 was estimated at around 2,400,000, rising to almost 3,000,000 in 1918. ${ }^{5}$ In 1922 Imām Yahyā told Ameen Rihani that he ruled over 5,000,000 people, although Rihani believed it was closer to 3,000,000. ${ }^{6}$ By the early 1940 s there were conflicting claims for the population of the kingdom, from as little as $2-3$ million $^{7}$ to over $4,000,000$. For the early $1940 \mathrm{~s}$ the Italian researcher Lambardi recorded a population of 4,069,087, with 55\% Zaydī and 45\% Shāfi'‘̄ as well as a minority of Ismā'îlì at about 50,000. At the time there were said to be $60-70,000 \mathrm{Jews}^{8}{ }^{8}$ A report from 1947 , however, reduced the total population to about 3,000,000 due in large part to emigration. In 1962 the population of the kingdom was estimated at 4,300,000 with an additional 910,000 in Aden and the Hadramawt. ${ }^{9}$

Yemen's rich agricultural heritage, stemming back to the Bronze Age and pre-Islamic kingdoms through the Rasulid era (13th-15th centuries) has been well documented. ${ }^{10}$ Several travellers to northern Yemen during the second Ottoman occupation (1871-1918), including the Austrian Eduard Glaser and the Italian Renzo Manzoni, commented on Yemen's agriculture at the time. ${ }^{11}$ There is a comprehensive analysis in German of these and other 19th century sources on agriculture by Adolf Grohmann. ${ }^{12}$ During the British control of Aden, their colonial reports and special studies describe local agriculture, especially for the Hadramawt. ${ }^{13}$

The remainder of this monograph is devoted to eight sources that provide information on agriculture in Yemen during the early part of the 20th century until the end of the Zaydi imamate in 1962. While much of the traditional systems of cultivation and irrigation had changed little over the years, new crops were being introduced. Four of the sources, translated from the Arabic, are by Yemeni authors, one is by a Syrian journalist visiting the Yemen of Imam Yahyā, one by an Italian Orientalist and another is a description of a report by an FAO team from the 1950s. Following these sources, a brief overview of agriculture during the kingdom is provided.

\footnotetext{
${ }^{5}$ Al-Wāsi'î (1927: 291, 319) estimated the population of Yemen at 15 million, with 5 million in the Tihāma, but this is clearly well off the mark. In 1886, Glaser (Grohmann 1922: 47) estimated the northern area controlled by the Ottomans as having 1.8 million. A dispatch by the U.S. Consul in Aden in 1922 estimated the population of the kingdom at around 2 million, with the number of people in San'à' at 200,000 (Sinclair 1976(1): 13). As noted by Steffen et al. (1978: I/85, 90-91) there were no accurate population statistics for North Yemen before 1975, when the Swiss-conducted census estimated the de facto population at 4,705,000 with some 330,000 Yemenis said to be living abroad.

${ }^{6}$ Rihani (1930: ix, 98).

${ }^{7}$ Naval Intelligence Division (1946: 364).

${ }^{8}$ Lambardi (1947: 156).

${ }^{9}$ Tarsīsì (1962: 210). Sharafaddin (1961: 7) suggests 4,000,000 in "Free Yemen" and 1,434,000 in the "Occupied area". According to Ruiz (1966: 1250), records kept by the Imam Ahmad indicated a population of 4-5,000,000.

${ }^{10}$ For recent studies of agriculture and irrigation in South Arabia before Islam, see Harrower (2016) and Maraqten (2017); for Rasulid Yemen, see Varisco (1994).

${ }^{11}$ Glaser (1884), whose work is described by Dostal (1993) and Manzoni (1884), which has been translated into Arabic. See also Millingen (1874).

${ }^{12}$ Grohmann (1922: 203-272).

${ }^{13}$ See Hartley (1944), Ingrams (1936) and Serjeant (1964).
} 


\section{1. 'Abd al-Wāsi' ibn Yạ̣yā al-Wāsi'ī. Ta'rīkh al-Yaman. Cairo: Maṭba'at Ḥijāz̄̄, $1366 / 1948$}

One of the most useful descriptions of agriculture during the early part of Imam Yahyā's reign is the historical survey written by 'Abd al-Wāsi' ibn Yahyāa al-Wāsi'ī, first published in $1346 / 1927$ and expanded in 1366/1948. ${ }^{14}$ In his edition of a text by the Yemeni author al'Arshī, Anastase de St-Elie calls al-Wāsi'î's history the best in its genre and he borrows heavily from it in his annotation of al-'Arsh̄̄'s work. ${ }^{15}$ Al-Wāsi'î’'s text is subtitled Furja al-humūm waal-huzn fi hawādith wa-ta'rīkh al-Yaman (Relief from Grief and Sadness regarding Current Events and the History of Yemen). The original publication in 1346/1927 consisted of 400 pages and was divided into two main parts. The first covered the history of Yemen from the time of the Prophet Muhammad up until 1346/1927, with a lengthy discussion of the second Turkish occupation. The second part addressed geography and politics, including the 'Asīr region and ethnographic details on educational institutions, women and marriage.

The author's full nisba includes al-Zaydī, al-Yamān̄̄, al-Ānisī, al-Șan'ānī and he lived from $1295 / 1878$ to $1379 / 1959$. He studied a variety of Islamic sciences and memorised the Qu'rān in Șan'â' and Zabīd, then went to Mecca and also Damascus and Cairo, where he studied at alAzhar. From his many studies he wrote al-Durr al-farìd al-jāmi ‘ al-mutafarriqāt al-asānīd and in all completed some twenty books, among then a short astronomical almanac called Kanz althiqāt fì 'ilm al-awqāt (The Reliable Treasure for Timekeeping). He was well-known for his teaching and preaching in the Great Mosque of Șan' $\bar{a}$ '.

Al-Wāsi‘'i provides a lengthy discussion on Yemen's agriculture in the 1920s, as translated below. At the time Yemen's major export was coffee, but trade was also made in hides, tobacco, some samn, honey, sesame oil, and grains when they were abundant. Near the end of his discussion on agriculture, he noted that most of the water in the wādīs does not reach the sea but settles into the ground, and he was hopeful that by sinking wells the barren desert could be transformed into a garden (tahawwalat tilka al-ṣahâari al-qāhila ilā jannāt). He goes on to say that Yemen has a rich tradition of irrigated agriculture but modern agricultural methods and systems can be built on this, perhaps making the Tihāma appear like California with the introduction of mechanical pumps. The highlands are said to be suitable for temperate climate plants and he optimistically thought it possible that crop production would one day rival Egypt and India. ${ }^{16}$

\section{Translation:}

Chapter 9 on the city of $\operatorname{San}^{‘} \bar{a}, 17$

[29] Around San'ầ' are towns, villages, suburbs (irbāẹ), as I will mention... [30] Bi’r al-Azab has many gardens, a variety of trees and excellent fruit. Every house has a garden (bustān).

\footnotetext{
${ }^{14}$ Few details are available on the biography of this Yemeni scholar, apart from the account in alMar'ashalī (1427/2006: 836-837) and online by Ilhām 'Abd Allāh al-Wāsi'ī

(http://www.ahlalhdeeth.com/vb/showthread.php?t=321329). He is praised for distributing an original copy (kurrāsa) of the Musnad with comments that would benefit all Islamic legal schools.

15 al-'Arshī (1939: 261-26). This includes information on agriculture quoted verbatim from al-Wāsi'ī (1927:136-137).

${ }^{16}$ al-Wāsi'īi (1927: 348).

${ }^{17}$ I only translate the information on agriculture and water sources here.
} 
There is a water channel that enters here from the south, irrigating al-Șāfiya to the south of San' $\bar{a}$ ', and the name of this watercourse is Ghayl Ālāf. ${ }^{18}$

Al-Rawdia: This is a suburb about an hour and a half north of San' $\bar{a}$ '. It is famous for its kinds of grapes. There are twenty one or more varieties of grapes in Yemen, the first being the most famous. These are arranged in alphabetical order: așābi 'Zaynab, al-ațrāf, al-biyāe (which is the sweetest and the best white variety is from al-Rawḍa), bayd al-hamam (so-called because the size of the grape resembles that of a pigeon's egg), al-jurash $\bar{\imath}$, al-jawfì , al-hātimī, al-

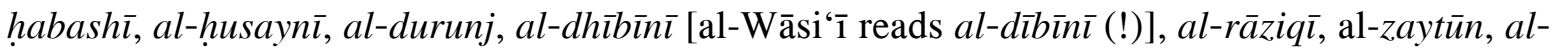
saysabān̄̄, al-'adhārī, al-'irq, al-'uyūn, al-'așamī, al-qazāqiz, al-qawārīr, and al-qahmī... ${ }^{19}$

To the east of al-Rawḍa is Șaruf (pronounced like 'adud), which is also famous for its grapes, especially on rainfed land ('aqar), which does not receive rain except for once or twice a year. When the grapes are irrigated by well water or water channels, the sweetness is less. The term 'aqar is known as ba' $l$ in Egypt and Syria.

Sa'wān (pronounced like sakrān) is an hour and a half to the east of Șan'ā'. It has many fruits and is famous for its watermelon and yellow melon (al-bittikhh al-ahmar wa-asfar). Recently [31] a yellow variety called sant in Egypt and Syria, and also 'ajū $r^{20}$ in Syria, has been planted. This has an aroma and the mark of its sweetness is its intense aroma. Also planted here is cucumber (khiya $\bar{a})$ and fig $(t \bar{t} n)$, which in Yemen is called balas.

Hadda is famous for a spring called 'Ayn Humays (pronounced like Zubayr). Among the fruits it is famous for are apricots $($ barqu $q$ ), which are mishmish in Arabic dialects outside Yemen, ${ }^{21}$ and walnuts (jawz). In Hadda there is a mill, turned by the water of the spring. To the east of Hadda is Sinā' (pronounced like siḥa $b$ ), which has many trees. To the east of Sinā' is Hamil (pronounced like hadhir), where most of the trees are pear (kumathrā) and plum (ijjās).

To the west of Șan'ā', about a half-hour distance, is 'Așur (pronounced like 'adud), which has apricot and fig. It is named after a mountain near it. 'Așur is two villages: upper and lower ('Așur 'ulyā wa-'Așur suflā), with a large watercourse flowing into them. These two are inhabited areas near Șan' $\bar{a}$ '...

Ghaḍān (pronounced like sakrān) is famous for its grapes, especially the rāziqī variety, a grape of long length without a seed. When you bite into it, the color is that of gold.

Qaryat al-Qābil (pronounced like 'ālim) has varieties of grapes and figs. Imām Yahyā called this village al-Rawd.

[32] Thaqāb (pronounced like sakrān) has varieties of grapes and figs.

Wādī Zahr, which is connected to a mountain by this name, is a large Wādī which is a major watercourse (nahr). In it there are varieties of fruits and crop produce, flowers of different colors and birds singing. Each village is elevated over the water, with gardens to the left and right of someone. At the lower part of the Wādī is Qaryat al-Qābil, previously mentioned.

\footnotetext{
${ }^{18}$ For details on the old ghayl systems of Șan'ā', see R. B. Serjeant and Ronald Lewcock (2013: 19-31) and 'Aslān (2000).

${ }^{19}$ Several of these varietal names are after place names. Al-'Anșī (1998: 119) lists 40 varietal names of grapes in Yemen. Rossi (1939: 166) lists 12 varieties for Șan'ā' .

${ }^{20}$ This is a smaller melon than the shammām.

${ }^{21}$ Al-Wāsi'ī notes in a footnote that barqūq is not originally an Arabic term. It is mentioned in Lisān al'Arab as a synonym for mishmish.
} 
Al-Dila' (pronounced like surad) has many trees, but these were torn out several years ago and $q \bar{a} t$ was planted in their place. ${ }^{22}$

Al-Kibs is south of Șan' $\bar{a}$ ' and it is a city of scholars and erudition with a population of Ashrāf. It has many grapes. It is part of the land of Khawlān, one of the famous Yemeni tribes. $Q \bar{a} t$ has been planted there...

[34] Zabīd ... around it are tall date palms and excellent palaces. It is 40 farsakh to the southwest of San' ${ }^{\prime} \bar{a} \cdot{ }^{23}$ It has a lot of water, fruits and large gardens. Its dates are from every color: red, yellow and green. It also has a lot of white jasmine (al-fill al-abyad), jasmine, screwpine $(a l-k \bar{a} d h \bar{\imath})$ and a variety of flowers that oils and essences are taken from.

[36] Șa'da ... has grapes, fruits, varieties of crop produce and legumes (buqūl) known in the regions of Syria.

[39] Hadramawt ... is an agricultural land. When you see its date palms, cereal grains, ( $h u-$ $b \bar{u} b$ ) and hamūmi tobacco (tibagh, known as tutun), these are among its most important exports.

Some of the watercourses (anhār) or flowing water sources (ghuyūl), their wādīs and floods

[83] The Yemenis say ghayl, with a fatha over the ghayn and a plural of ghuyül, for a water channel (nahr). The most famous of the ghuyūl of Șan' $\bar{a}$ ' is Ghayl al-Aswad, which travels to two mosques (masjid al-Mutawakkil and masjid Hajar), then waters the garden of al-Mutawakkil, and departs to Shu'ūb, north of Șan'ā', where it irrigates the fields until al-Jirāf.

Ghayl Ālaf travels to Bi'r al-‘Azab, after watering al-Ṣāfĩya, which has fields and crops south of Șan'ā'.

The water of Ghayl Abī Țālib flows to al-Rawḍa and its source is east of Shu' $\bar{u} b$, below the village of al-Ḥăfa. It was opened up by Ṭughtakīn ibn Ayyūb, ${ }^{24}$ but when the government and succession went to the imam al-Manșūr bi-Allāh al-Qāsim ibn Muhammad, he named it for his son Abī Ṭālib Ahmad ibn al-Qāsim. ${ }^{25}$ Some of this is waqf for the estates in Darb al-Salātīn [134] in al-Rawḍa, al-Halla and Bi'r Zayd, and other parts are for the mosque of al-Rawḍa. This functions until the present, sometimes with increased flow and sometimes weak.

Ghayl al-Imām al-Mahdī is for al-Mahdī Aḥmad ibn al-Ḥusayn and irrigates al-Rawḍa ${ }^{26}$ It was opened up by the governor $(w \bar{a} l \bar{l})$ Muhammad 'Izzat in $1302 \mathrm{~A}$. H. The best of its flow went to al-Rawḍa. Its cost was very expensive. Later it was purchased by Shaykh 'Alī al-Balīiñ.

The source of Ghayl Muștafā is higher than that of Ghayl al-Mahdī and nearer to Șan'à'. Its water was cut off for awhile, but in the government of Ahmad Fayḍi Bāshā in 1310 A. H. it was opened up and restored. After being restored, it was purchased by Shaykh Muhammad al-Balīlī.

The emir Țughtakin, who became the ruler of Yemen, let himself be deluded into buying all of Yemen's land, so that all of Yemen would belong to him. This was a burden on the people of

\footnotetext{
${ }^{22}$ This is probably in reference to al-Dilā' ' Hamdān, where former YAR President al-Ghashmī was born.

${ }^{23}$ The distance term farsakh, originally from Persian, can refer to different lengths. It originally referred to the distance that could be covered on foot in an hour, ranging up to $6 \mathrm{~km}$ in Iran. The distance from Șan'ā' to Zabīd is about $160 \mathrm{~km}$, as the crow flies. This indicates that al-Wāsi'‘ ì is probably assuming the farsakh to be similar to the marhala. Assuming the distance covered be could be up to $40 \mathrm{~km}$, this would imply a trip of four to five days or so, depending on the terrain.

${ }^{24}$ Țughtakīn was the brother of the Ayyubid founder Salāh al-Dīn. In 1182 CE he succeeded his brother Tūrānshāh as the second Ayyubid emir in Yemen. He died in 593/1197. There is an error in the published text of al-Wāsi'ī of 543 instead of 593.

${ }^{25}$ This imam led a revolt against the Ottomans in the 17th century and founded the Qāsimī dynasty.

${ }^{26}$ Al-Mahdī Aḥmad died in 1681.
} 
Yemen. A group of nobles gathered and entered a mosque and would not leave the mosque until it was destroyed. They entered the mosque and stayed for three days, fasting during the day and standing up during the night. On the third day Tughtakīn died, his death coming in Shawwāl, 593 A.H.

This is for Șan' $\bar{a}$ ', but the following are the other watercourses (anhār) and wādīs in Yemen: Wādi Mawr collects from a number of Yemeni water sources, which is why it is called the water outlet $(m \bar{\imath} z \bar{a} b)$ for the Tihāma. Wādī Banā collects a number of watercourses, including al-Dalānī, Ḥawra, al-Radā'‘̄ and al-Juban, and then descends to Lahj, benefiting all the areas it passes through.

Wādī Hindūwān is a large Wādī passing through Ta‘izz until near Mocha. Wādī Sihām is a group of watercourses which separate and then all of them pass through the Tihāma. Some of these reach the sea, such as Wādī Khidār, Sāmik, Hậaid, A'shār, Buqlān and Wādī al-Tālūq. AlKhārid gathers the water from 'Ans, Dhamār and Radā', then passes to the north east to Ma'rib and finally to al-Khārid.

There are other sources of water near Șan ' $\bar{a}$ ' that drain into al-Khārid. Then there is Wādī alSirr and Sayl [85] Sa'wān, which only has rainfall. The floodwater that descends from Jabal Lawz after rainfall enters Șan' $\bar{a}$ ' in the well-known floodbed, then to Shu'ūb and al-Rawḍa.

Other wādīs are Wādī al-Tanā'um, Wādī Sahar, Șabir, 'Āshir, Ramak, Ghaymān, Mulhạ̄' in the Jawf, Qarwā Sayyān, and many other Wādīs in al-Hayma and Ānis, but the most famous are those mentioned here... The wādīs of the Tihāma and 'Asī ${ }^{27}$ are fertile and can be cropped three times a year. The most fertile is Wādi Yabā. ${ }^{28}$ The area of its crops is at the level of cultivation of the Egyptians, some 70,000 faddān of [86] the best quality land. The faddān in the usage of Yemenis is 75 lubna. The lubna is 10 iron ells (dhirä', sg.; adhra', pl.). There are 7,500 iron ells in a faddān. ${ }^{29}$ The length of the wādi from east to west is $70 \mathrm{~km}$, and from north

\footnotetext{
${ }^{27}$ In her trip along the coast of "Așīr in 1922, Forbes (1923: 275) noted the following crops: "The main cultivation is in the Wādīs, where durra, dukhn, sem-sem, many kinds of vegetables, hemp acid, incense plants and ful [i.e. jasmine], from which strong scent is ground-level rises, there is wheat and a little barley, while from come coffee, bananas, roses, grapes, almonds, papaia, custard and melons." Traveling through the "Asīr coast in 1946, Thesiger (1947: 191) writes: "The two staple crops are dhurra which is grown on the silt deposits, producing from three to five ratoons from one so wing, and dukhn which is generally sown as a rain crop on the "khabt" or sandy land between the Wādīs. Dhurra is first harvested three months after sowing and then every two months, while dukhn is cut only once after three months. Stalks of dhurra, but not dukhn, even when dry, are valuable fodder and the crops ripening in July and August are used solely for this purpose since the burning winds at that season parch up the grain. Simsim is grown on the edge of the flood lands where a small amount of cotton and beans is also cultivated. The Tihamiyin have no rotation of crops and sow as often as there is a flood. There are small gardens round some of the wells where tomatoes, aubergines, ladies fingers, pumpkins, water melons, sweet melons, and sweet-scented herbs are planted. No onions, garlic, or red pepper are grown here; these with lemons, grapes, apricots, peaches, pomegranates, bananas, potatoes, and the herbs "birk" and "ashar" are brought down to the markets from the Hijaz. Date palms are few and grow mostly in the upper Yaba and along the coast between 'Amq and Qahma, the bulk of the dates consumed arriving by sea or from the Bisha oasis." Describing the agriculture near the Yemen border, Thesiger (1947: 196) adds: "Jabal Faifa, 6000 feet high on the Yaman border, is extensively terraced and coffee, "qat" (Catha edulis), bananas, pawpaws, grapes, pomegranates, peaches, prickly pears, dhurra, wheat, and barley are cultivated. The neighbouring Jabal Bani Malik, 7500 feet high, is also terraced and coffee, bananas, dhurra, wheat, and barley are grown there. Qat from Faifa is sold in the Tihama at Qizan Sabya and 'Abu 'Arish and fetches a very high price but nowhere else in the Tihama, Hijaz, or 'Asir is it grown or eaten."

${ }^{28}$ Wādī Yabā or Yabah is located in the district of al-Qunfudha in Saudi Arabia.

${ }^{29}$ For a description of measures and weights in the Mutawakillite Kingdom, see Table 1.
} 
to south almost $8,000 \mathrm{~m}$. Its crops are sorghum (dhura), bulrush millet (dukhn), sesame, indigo, lemon, green vegetables and various flowering tree crops.

Wādi Halī is famous for its resources and is three times the size of the first [i.e., Wādī Yabā.${ }^{30}$ Between these two and Sabyā to the northeast is some 7 day journeys (marāhill). ${ }^{31}$ In Wādī Hawā' they plant what has been mentioned, including wheat (burr), and there are many trees, such as juniper ('ar'ar), almond (lawz), fig (tīn), grapes ('inab) and other fruits. ${ }^{32}$

Wādī Bāriq is very fertile and it comprises 50 villages. ${ }^{33}$ Some of the crops of these Wādīs include coffee (bunn) and date palms (nakhīl).

From Ranya of Ghāmid northward to $\mathrm{Abh}^{-34}$ is a 10 days journey. There more than 100,000 date palms are raised. In Wādī Turba and its environs there are what exceeds 100,000 date palms.

Among the Wādīs of Yemen is Wādī al-Sirr and its mountains of Kalsiyya, where there are many grapevines (kurüm). Planted here is lucerne (qaḍ), also known as fișs a and called birsìm in Egypt, as animal fodder, as well as wheat, barley, sorghum and some figs (balas). There are also non-deciduous trees.

[87] Wādī Harīb (pronounced like kabīr) is rich in plants such as the mastic tree (darw), ${ }^{35}$ fuhiyya $^{36}$ and fumitory (shāh al-turunj) ${ }^{37}$, which is al-bādhrinjūwìya. There are also nondeciduous trees like christ's thorn ('ilb) ${ }^{38}$ doum palm (düm) ${ }^{39}$ bashr, ${ }^{40}$ wild fig $(a t h a b)^{41}$ from which the people take the wick ( $f a t \bar{l} l)$ for old-fashioned muskets, acacia (al-sumur), etc.

\footnotetext{
${ }^{30}$ Thesiger (1947: 191) notes, "Last year [i.e., 1945] the main irrigation bank in the Hali gave way and the Wādi above Baidhain was deserted, its inhabitants having moved to the Yaba. Floods, which may occur in any month but are most usual in the winter and autumn, are held up and distributed over a large area by a number of these banks called "zabir", needing constant attention. These floods cannot be controlled and damage may result from flooding on young crops."

${ }^{31}$ Al-Barakātī (1384/1964: 58) writes that a marhala with a camel is about 40 kilometers. Thesiger (1947: 197) saw indigo being grown near Șabyā.

${ }^{32}$ Al-Barakātī (1384/1964: 62) for this wādī lists wheat, barley, much sorghum, almond, figs, grapes, peaches, etc. and notes that it is famous for its juniper trees.

${ }^{33}$ Al-Barakātī (1384/1964: 54) for this wādī notes sesame, sorghum, barley, millet, indigo; he adds that sesame oil was exported from here.

${ }^{34}$ Al-Barakātī (1384/1964: 72-73) provides the prices of various wheat, samn and tobacco in Abhā at around the turn of the 20th century. Thesiger (1947: 195) visited Abha in May, 1946, noting: "In these mountains wheat ("burr") or barley ("sha'ir") is sown in the winter and dhurra in the summer. I arrived at Abha on May 2. While many of the fields were bare, some dhurra was already sown although the barley and wheat were not yet all harvested. The cultivated slopes are everywhere terraced and a few fields are irrigated from the wells. Apricots, peaches, plums, pears and small green apples, grapes, pomegranates and figs, prickly pears and almonds are the fruits grown in the Hijaz."

${ }^{35}$ Pistacia lentiscus. Al-'Azm (1986: 340) says that part of the branch is boiled in water and drunk for disease of the liver and kidneys.

${ }^{36} \mathrm{Al}$-'Azm (1986: 340) said this tree is very aromatic and it is cooked with fenugreek or added to yogurt, as you would withmint. In Ta'izz and al-Hujariyya this term refers to an aromatic dwarf shrub from the Asteraceae family that is used by women under their head covering to give them a nice smell (Dr. Abdulrahman Aldubaie, personal communication).

${ }^{37}$ Shähturunj is the Persian term for Fumaria officinalis.

${ }^{38}$. Ziziphus spina Christi.

${ }^{39}$ Hyphaene thebaica.

${ }^{40}$ I have not been able to identify this tree variety.

${ }^{41}$ Ficus salicifolia.
} 


\section{Crops $(z u r \bar{u})$}

[138] In Yemen there are many varieties of grains (hubūb), crops $\left(z u r \bar{u}^{\circ}\right)$, plants, fruits and trees. Wheat (hinta), is called burr ${ }^{42}$ for what is called qamh outside Yemen. The varieties extend from red [139] to white. The best quality is al-burr al-"Ansī in the basins of "Ans and Dhamār. After this is al-burr al-Bawnī from Q⿳亠口冋' al-Bawn, a wide district six hours north of Șan' $\bar{a}$ '. In addition to planting this there, another variety is called samrā'. Red (ahmar) to dark $(\operatorname{sawa\overline {d}})$ is sown in Shu'ūb and al-Ṣāfîya and other parts around Șan'ā’. The best variety for bread is 'alas (emmer wheat), which is called nusül. The people of Yemen are masters of bread making from varieties of wheat. ${ }^{43}$ There is a variety of bread called fuh $\bar{u} q$ and another called $m a \bar{u} \bar{j}^{44}$ and $s a b \bar{a} y \bar{a}$, which are kneaded with ghee (samn). There are different types but each are called malūj and muqawwa' (flat). The reason for calling it $k h u b z$ is that it is flat (raqiq $)$ and round (mudawwar) and is baked in regular ovens and clay ovens (tanāwìr). The latter are found in Damascus but not in Egyptian areas. Malüj is only for the tannūr and its specific shape is round and it can be up to twice the size of other bread but the author likes a small amount of milk in it. If wheat is kneaded with ghee or egg, one of the varieties is dhamül. Bint al-sahn is baked in a similar fashion, and a variety called sūsì is made with egg, milk and ghee.

As for barley (sha' $\bar{\imath} r$ ), there is a variety known as saqla, which is thinner than ordinary barley grain, which is very white, and only wheat is eaten more in bread. It is only made into malüj. Then there are white, red and yellow varieties of sorghum (dhura), for each of which there is a name. Maize (al-dhura al-Shāmìya) is called Rūmì or Shām by Yemenis. Other crops are millet $(d u k h n)$, cowpea (lübiyā), broad bean (fül), teff (tahaf), lentils ('adas), peas (julubbān), which are called 'atar in Yemen and are similar to bisilla in Egypt and Syria, sesame (simsim), mustard (khardal), from which an edible oil (duhn) is made, and poppy (khashkhāsh).

Yemen has various aromatic plants and flowers, including rose (ward), jasmine (yāsaminn), Arabian jasmine (fill), narcissus (narjis), violet (banafsaj), and varieties of sweet smelling plants. If any of these are not present in Șan'ầ', they are found in other areas of Yemen such as Zabīd, Lahj and in lush wādīs of the western area. There are also marjoram (marzanjūsh), lavender $(k h u z \bar{a} m \bar{a})$, which is called raymān, dill (shibith), which is called zuqīqu, [140] screwpine $(k \bar{a} d h \bar{l})$ and mint (na'na'). Fruits include grapes ('inab), in all their varieties, which I mentioned in Part 9 in the account of al-Rawdia. The dhībini grape is the best black grape variety for sweetness and lack of a seed in it. Its individual parts are tightly packed together on the vine. The red varieties are zaytūn and 'ạsamī, the latter being called hulwān̄̄ in Syria, but the sweetness of the Syrian is less than the sweetness of the Yemeni. For all of these sweet varieties, some Syrian grapes are sweet like the Yemeni, such as the red (ahmar).

\footnotetext{
${ }^{42}$ Burr or birr is found in South Arabic as well. Al-Iryānī (1996: 62-64) discusses the history of the term and its use in Yemeni proverbs and poetry. When the Syrian traveler al-'Azm (1986: 91) visited Yemen in 1927, he said he had no idea that burr meant wheat and remarked on a number of words that were exclusive to Yemeni dialects.

${ }^{43}$ For more details on Yemeni varieties of bread, see al-Akwa' (1979: 137-150).

${ }^{44}$ As explained by al-Iryāni (1996: 836-837), malūj can be made from wheat or barley and is the largest bread made in Yemen. The method of making it is to take a small ball of dough and take it in your hand with ghee or cooking oil or wet fenugreek. Then flatten the ball to the side of the tannūr so that it sticks to the tannür wall. He notes that the woman doing this must have patience due to the heat of the tannür. Al-Akwa' (1979: 149) notes that it is made without yeast.
} 
As for figs ( $\operatorname{tin})$ in Yemen, most varieties are black (aswad) and figs are called balas by Yemenis; I mentioned them on p. 21. There is also a thorny fig called Turki in Yemen and subayra in Syria. ${ }^{45}$ The apricot (mishmish) is called barqūq in Yemen and it is not the same as the apricot in Syria, which is not present in Yemen. The Syrian apricot is much sweeter than the Yemeni. Peach (firsik) in Yemen is called injās outside Yemen, but the injās of Yemen is a different variety than that of Egypt and Syria. Pear ('anbarūd) is also called kumathrā in Yemen, which is an original Arabic term. Yemen also has a sour red mulberry $(t \bar{u} t)$, but the white variety is in Syria and is sweet as sugar, as well as a red variety. The sweet variety is in al-Ṭā'if, India and Iraq. Yemen has bananas (mawz), ${ }^{46}$ walnuts (jawz) and lots of almonds (lawz). The varieties of dates are not in Șan'ā', but in Zabīd, Najrān and 'Asīr. Yemenis call tamarind humar. There are sweet and sour pomegranates (rummān) as well as quince (safarjal), and the sweetness of pomegranates and quince is greater than that of Syrian and Egyptian pomegranates. As for the quince in Egypt, it is only known by this name. There are sweet and sour lemons, but the citron (utrujj) in Yemen is different from that present in Egypt and Syria. ${ }^{47}$ Other plants include pseudo saffron (wars), which is the same as $\bar{a} s$ and hadas, safflower ('usfur), indigo (nīl), henna (hinnā), and ginger (zinjibìl) in Rayma, Hufāsh and Lā'a.

Frankincense (al-lubān al-dhikr) is in the mountains of Hadramawt and al-Shihr. This is called kundur and in Yemen it is al-lubān al-Shihrī. There is myrrh (murr) and mastic (maștaqā), a resin I saw in Ghamdān and northern 'Asīr, as well as cummin (kammūn), anise (ansūn), fennel (shamār), guava (jawāfa) in Lahj ${ }^{48}$ like that of Egypt, and mango ('amb) called manja and $a m b \bar{a}$ ' in Egypt. ${ }^{49}$ [141] I saw custard apple (khirmish), called qishta in Egypt, in Lahj and al-Hudayda, brought in from the surrounding area ${ }^{50}$ In Lahj and al-Hudayda I saw fruits with a size smaller than melon (bitțikh) and very yellow in color and I did not see anything like it in Egypt or Syria. Eating it is commended for its sweetness; it has small, very black seeds. Nigella (quhța) is al-habba al-sawdà' and is called shawnīz and al-habba albaraka in Egypt and Syria.

There are many kinds of vegetables (khadrawāt) present in Yemen, such as the long snake cucumber (qithth $\bar{a}^{\prime}$ ), which in some areas is called qatt, a common misperception, and the sleek and smooth one being khiyär. There are varieties of watermelon (habhab), called bitțikh outside Yemen. ${ }^{51}$ The cantaloupe (shammām) is newly planted by older people in Yemen. Sugarcane (qașab al-sukkar) is present in Yemen. A reddish sugar called 'ațwi in Yemen is made from it. In Șan'ā' and al-Hudayda they make sugar (al-sukkar al-nabāt) and other sweets are made for

\footnotetext{
${ }^{45}$ Balas Turkī is Opuntia fucus-indica or cactus fruit, which was originally from Mexico.

${ }^{46}$ Al-Barakātī (1384/1964: 161) notes that bananas are plentiful and cheap in the Tihāma.

${ }^{47}$ Al-Wāsi'ī (1947: 130) has a lengthy discussion on the usage of Burtuqāl for citrus in Yemen. He notes that it is a type of līmūn which resembles the orange (nāranj) in size and color. He brought tangerine (Yūsuf Affandī) from Egypt and recently planted these.

${ }^{48}$ Scott (1939: 100) also records guava in Lahj, among other fruits.

49. Al-Barakātī (1384/1964: 161) notes that mango (anbā) is plentiful in the Tihāma.

${ }^{50}$ Scott (1939: 100) saw custard apple in Lahj. In the 1927 edition al-Wāsi ‘̄i adds here: "I had not tasted this until the year this book was published in Egypt. I was in the house of my friend, the noted scholar Ahmad Zakī Pasha when I first tasted it."

${ }^{51}$ In the 1927 edition, al-Wāsi‘'i adds: "such as the red and yellow and one variety called khirbiz and green melon ( 'ajjūr) are not planted in Yemen, except for a variety in palace garden cultivation. While the Ottoman Empire ruled Yemen for some time, there was no focus on developing agriculture, trade , industry, education or the spread of modern knowledge. When Imam Yahyā entered Șan 'ā' he found it ravaged, so now he revived it like a fresh robe and famous Yemeni coffee."
} 
festivals and celebrations. Yemen has many trees which blossom and others such as gum trees (samgh) and aloe (al-sabr al-Hadramī), as well as cotton..$^{52}$ Also present in Yemen is tobacco (tibgh), which Yemenis call tutun with varieties known as hamūmī, al-khabțī, and jumayrī, the first being the most famous. ${ }^{53}$ These are exported to several countries...

\footnotetext{
${ }^{52}$ In the 1927 edition, al-Wāsi ‘ī adds: "During this time the Mutawakkilite Kingdom places importance, with the help of Allāh, in spreading the planting of cotton in parts of Yemen." In his trip to Yemen in 1927, al-'Azm (1986: 26) was told that Imam Yahyā had imported cotton seed from Egypt and America and wanted to have it grown all over Yemen. Rosita Forbes (1923: 275) reported cotton being grown in the 'Asīr region around Wādī Jāzān.

${ }^{53}$ Al-Barakātī (1384/1964: 161) records tobacco (tunbāk), a variety of which is called akhdar in the mountain region (sarāt). Ingrams (1943: 156) describes tobacco grown near al-Mukallā. The Turkish term tutun is generally reserved for black tobacco (Nicotiana tabacum) with pink or white flowers and grown at elelevations between 4,500-5,600 feet in the Amīri highlands of the south, while tunbāk was used for the yellow-flowered Nicotiana glauca (Naval Intelligence Division 1946: 494).
} 


\section{Muḥammad ibn 'Alī al-Akwa'. Șaḥfat min ta'rīkh al-Yemen al-ijtimā' $\bar{\imath}$ wa-qișșat hayātī. Damascus: Maṭba'at al-Kātib al-'Arab̄̄, 1979}

Qạḍ̄ị Muḥammad ibn 'Alī al-Akwa' al-Ḥiwālī was one of the most important Yemeni historians of his generation, especially for his editions of works by the tenth century Yemeni savant alHasan al-Hamdānī. He was born in Dhamār in 1321/1903 and died in 1419/1998. He was thrown into prison in Hajja twice, first by Imam Yahyā and then by Ahmad. After the Republican revolution in 1962 he served as a deputy to the Minister of Justice, then later in the ministries of $A w q \bar{a} f$ and Information. He is the brother of Qāḍ̄ Ismā'îl al-Akwa', another respected Yemeni historian.

\section{Translation:}

'Allān [124]

The season of 'allān is one of the seasonal periods and festivities throughout Yemen. This is the harvest time in autumn's days. There is rainfall and the start of crop produce, which is almost mature, from all the kinds of crops, such as sorghum, wheat, broad bean (qillā or fül), barley, lentils (bilsin or 'adas) and maize (Shäm or dhurra safrä'), with others besides these.

Perhaps it is called 'allān because the season of autumn announces (a'lana) the season of winter. The days of 'allān are the most significant of the festivities, celebrations and pleasurable activities because every year people come alive with a pleasurable and comfortable way of life.

I discovered before that the term 'allān is one of the Himyarite months known as Dhu 'Allān, but the Yemeni people shorten the term and found it sufficient to say 'allān after the Himyarite period.

[125] Dhū 'Allān corresponds to the Syriac $A y l \bar{u} l^{54}$ and Christian September... As soon as the sky is clear from rain, people including children and women hurry out to their fields to collect weeds (hash'̄'ish) and pasture plants ( $a$ 'shāb), bundle them up and place them on the ground to dry. Eventually they take them to places where they are stored for winter and spring (sayf $)^{55}$ fodder for their animals. When they have finished this activity and the sorghum is close to being ripe, they do something called shiry $\bar{a} f,{ }^{56}$ which is a local dialect term not recorded in the dictionaries, and this is stripping the leaves from the sorghum stalks ('ajür), thinning them and throwing them behind themselves and bundling them to dry, proceeding in the same way as the purpose of the activity with the weeds.

In each activity of weeding or stripping sorghum leaves, you hear singing and shouting that fill the wādīs. The echoes of their voices ring out in the high mountain peaks, arousing sorrow and delight, as though the air is dancing for joy and delight, but sometimes people make light of this mirth on occasions when the singer loses his senses.

On all these occasions there are poems, folk sayings and charming melodies, [126] of which you will take the best part in what is coming after this. I memorised one in the village of al-

\footnotetext{
${ }^{54}$ In Yemen these month names are called $R \bar{u} m \bar{\imath}$, literally Byzantine, referring to the solar months of the eastern church.

${ }^{55}$ In Yemen the term sayf was traditionally used for spring.

${ }^{56}$ The more common term in Yemen is sharf, but there is a much older term, shirnäf, recorded in lexicons; see al-Iryānī (1996: 481-482).
} 
Dhārī, where they say: "Harvest, harvest, after the rains we thank God" (ghaltat, ghaltat, ba'd al-kharīf nahmadu Allāh). ${ }^{57}$

\section{Jahīsh and lasīs}

In this same season and during the same days the farming people and others, like visiting guests and those happening by in the wādī, use parched (jahīsh) sorghum. Jahīsh is a term used through every location in Yemen, without exception. It is derived from "he was about to shed tears" (ajhasha bi-al-bukā'), i.e. 'getting ready to', and jahsha means a flow of tears ('abra), or 'he hurried such a one' (ajhasha fulānān) or 'he rushed' (a 'jala). The way it is done is to go to the crooked panicle ( $s a b \bar{u} l$, i.e. sunbula) or seed cluster ('idhq), when it is fully grown, ripened and has become well-formed, cutting off a number of this kind of panicle. A fire is prepared, not stopping until the smoke is rising up and the panicle is placed on this fire, turning it around and placing one after another. When it is well done and parched, it is placed between the left and right hand and the seeds are rubbed out into a container or to a cloth on the ground. This is done when it is intensely hot and only a man with a strong and hard hand can tolerate the heat of the fire in his two hands. When everything is finished by filling the container or cloth to maintain the heat, then it is opened up and everyone takes a handful and blows on it, eating it while it is still hot. They all gather around and look at it and each tries to go before the other to take it, striving by this for such delicious food. [127] In every place where you see a wādī there are lights and smoke and you hear the shouts and cheers from all around the wādī. Amazement, joking and happiness enter into you.

Regarding lasis $\bar{s}$, this refers to what you eat when it ripens... ${ }^{58}$ The term lasiss is a Yemeni dialect term and mainly used for wheat (hinta), which is burr or qamh, as well as broad bean (qilla or fül), lentils (bilsin or 'adas) or peas ('atar or bisāliyā') or cowpea (dijr or lübiyā') or hyacinth bean (kishd) and even from sorghum (dhura). The lasis of these varieties in this season of 'allān is only in the land and mountains that plant in kharîf $f^{59}$ and harvest in 'allān. In Wādī al-Dhārī, however, they only plant wheat in winter (shitā'), but near the harvest they take lasiss.

The description of lasīs of wheat is when the farmer goes to his wheat fields and chooses the suitable spikes (sanābil) of grain for lasiss, gathering them by the qisla,${ }^{60}$ which is a bundle of spikes, then tying them at the bottom of the spikes. These are removed by its stems (hishri $)$, that is its woody stalks $\left(a^{\prime} w \bar{a} d\right)$. Each bundle of spikes is thrown to a place so that what is sufficient for the lasis can be gathered for a family or something like this is gathered up. Then that is taken to the house and the tannūr oven (tâ̄būn) is heated up. The spikes are held by the bottom of the wheat stalks (' $\bar{l} d \bar{a} n)$ over the fire in order to get rid of pests (marāqish) $)^{61}$ and wheat beards (marāqin), ${ }^{62}$ marāqin being the plural of mirqān and meaning that which is [128] like thorns $(a s h w \bar{a} k)$. Next to the oven (țābun or tannūr) is a woman who takes hold of the bundled

\footnotetext{
${ }^{57} \mathrm{Al}-\mathrm{Akwa}$ 's text reads 'altat 'altat, but this seems to be either a dialectical variant or a printing error for ghaltat, which refers to the harvest (hisad), according to a resident of al-Nādira, near where al-Akwa was born (Abbas Alsoswa, personal communication). In cases where rain is late in coming, it was customary to practice a rain invocation (istisq $\bar{a}^{\prime}$ ), as discussed by Rossi (1939: 187-188).

${ }^{58}$ Al-Iryānī (1996: 802) notes that lasīs is grain (habb) boiled in water.

${ }^{59} \mathrm{Al}$-Akwa' is using kharîf to refer to the late summer autumn rains in Yemen.

${ }^{60}$ Al-Iryānī (1996: 723) defines this as a small bundle (huzma șaghīra) of wheat or the like.

${ }^{61}$ I have not been able to identify this term, but al-Zabīdī $(r-q-s h)$ defines raqsh $\bar{a}$ ' as a small worm (duwayba) in pasture ('ushb).

${ }^{62}$ Al-Iryānī (1996: 361) defines marāqin as a pile (kuds or kawm), especially of bundled stalks.
} 
spikes from which the beards have been taken away. In her hands is a winnowing basket (minsaf), which is made from stalks and plant material ( $a$ 'shāb), and she winnows the spikes from underneath so the wheat kernels will fall into the winnowing basket and the chaff (qishra) removed. She winnows it until everything attached to the kernel will be removed so that she can complete the work and there will be pure kernels, which are placed in a pot (qidr) filled with water and boiled, then taken off the heat and not opened until ready.

Most of the lasis is eaten at night because it warms the body on winter nights due to the difficulty of digesting.

As for the lasīs of other kinds, as we mentioned for cowpea (lübiy $\bar{a}$ '), hyacinth bean (kishd), lentils ( 'adas) and broad beans (qillā), these are done in the same way as the lasīs of wheat...

$\underline{\text { Sugar cane (muddār) }}$ [129]

Muddā $r$ is derived from the verb madara sh' for when one bites with his teeth and sucks the juice from it, throwing away the parts left over and any remaining juice.

Mudd $\bar{a} r$ is a common Yemeni term and it is mentioned by al-Hamdānī in his unparalleled book Sifat jazīrat al-'Arab. ${ }^{63}$ In the town of Dhamār it is called la'ạs. Muḍārr is from sugar cane (qand or qașab al-sukkar) and sorghum cane (qașab al-dhura). Regarding sorghum stalk, it is for what is spoiled and does not give rise to heads ( $s a b \bar{u} l$ ) but holds a kind of sweet sugar, which is called labādi in al-Dhārī. The youth and some farmers take it and they bite into the hard part of it and chew the core, throwing away what is left. The season for sorghum cane only occurs in the month of allän. As for the season of sugar cane, we will mention it in what follows, as well as where it is grown.

The guard (shärih)

Wādī al-Dhārī lies between two mountain chains, west and east, like the rest of Wādī Khubān. One cannot descend to it or go up from it except by a special passage and known roads. When 'allān comes and the land is full of [130] crop produce, it is the suitable time to have a guard (shārih), a man on these gaps and roads watching those descending into and leaving the wādi . Shärih is a common Yemeni term, and hâm $\bar{\imath}$ is also said in the area of Dhamār and San' $\bar{a}$ '. Both terms are core language and recorded as in the dictionary rendering of shärih as a protector of the crop from birds and $h \bar{a} m \bar{\imath}$ as the one protecting.

For these guards there is a known payment paid to them at the surāb harvest from all the kinds of crop produce.

Whoever of the farmers returning from the wādī is loaded with fodder and flood-water sorghum heads, according to the amount of the agricultural area he owns, is allowed to pass without any trouble. Whoever has a small agricultural area or takes more than the amount of his land that he is taking it from is held responsible, since the guards have an intimate knowledge of their places according to their large fields (jirab) and small plots (ahwāl). Every day that they descend, they follow the tracks and observe corruption and change. They know the thieves, robbers and the like, returning everything to its place and family.

$\underline{\text { Harvest and sorghum threshing floors (al-surāb wa-jarīn al-dhura) }}$

Surāb is the harvest (hișa $d$ ) and is a dialect term in our common Yemeni tradition. The harvest of sorghum in the villages of Wādī Khubān is without exception as it occurs in several districts,

${ }^{63}$ Al-Hamdānī (1884: 193). 
which is harvesting the sorghum by its stalk and taking it to threshing floors (jarin) near the place. ${ }^{64}$ The hawl means the field (jirba) [131] where it is left between three weeks and a month so that the stalk absorbs more and becomes more mature, edible and of excellent quality until a greasy substance (dusüm) resembling clarified butter (samn) emerges when you twist it. Then you cut it off from the crook at the threshing floor and it remains for a few days, after which your beat it (talbiju ${ }^{65}$ or tadribu) with a stick specially made for this activity and this is called a mikhbat, the plural being makhābit, as well as the plurals mislabij and malälbij. ${ }^{66}$ They have a specific way to beat out the kernels, which is closely associated with songs and intonation during the activity. Then they winnow these with a madhāri (madhrā, plural), which is a wellknown tool made of wood, until the kernels are collected and become a pile $(s u b r a),{ }^{67}$ which is called an abla. Then it is measured in the cold period, with the sorghum being cold so that it can be entered into the granaries (madäfin) and remain for a year or years and they can take it out when there is a need.

When the sorghum on the threshing floors is still on its stalks, they select from it the heads that are pure with large kernels and take these for sowing (dhari or badhr) in the coming year.

The term jarin is well-known, the singular being jurn, and is also called bayādir, the singular being bayda $\bar{a}$. This is where you place the crop produce after its harvest from the large fields and small fields. Regarding the village of al-Dhārī, most of the sides of the Wādī are clear with areas of flat rocks. When the crop produce and grains are placed here and they want to beat them and tread on them, the kernels are spread around here so that it is important that they do their activity by surrounding the area with stalks and brush.

For this reason most of the peasants in Wādī al-Dhārī go to the side [132] of their field and harvest the sorghum in it and pull out the jadha, which are the bottom of the sorghum stalks (ușūl al-'ajūr al-qașab), leveling the land so that it can become a threshing floor. They take permission from the master for the process of threshing to come down to the Wādi to tread on this threshing floor with their feet until it hardens, doing so day after day, until it dries in the heat of the sun. When that threshing floor cracks open, it is patched with ashes and soft mud mixed with water and thus they fuse the cracks.

The opportunity for children in the case of these activities is one of the joys of their days and pastimes.

\section{Groom of the crows (hariwwat al-ghurbān)}

The harāra is the bride and the hari $w^{68}$ is the groom... As for the crows, in these days of the coming of 'allān they associate with the people through their cawing and screeching between the sky and the hills. There is a gathering in a circle called "the groom of the crows" like they are having weddings and festivals, since the crow when it takes the grain, whether in the mountain or the $w \bar{a} d \bar{l}$, prospers from freely eating what it finds as they move about.

The woman who brings food and the headgear (al-milhiqa wa-al-shüdhat al-tuhwäfa)

The milhiqa is the woman who brings a meal to the field for the plowman (batūl), [133] who plows the land. The shüdhat is like a kind of "packsaddle" ( $a k \bar{a} f)$ for the head, made from straw

\footnotetext{
${ }^{64}$ The text reads mawsi ${ }^{\circ}$ (!) instead of mawdi .

${ }^{65} \mathrm{Al}$-Zabīdī $(l-b-j)$ defines labaja as to beat with a stick.

${ }^{66} \mathrm{I}$ am unsure of the voweling of these two dialect terms.

${ }^{67}$ Al-Iryānī (1996: 27) defines this as a pile of grain before it is weighed or measured.

${ }^{68}$ For an extensive discussion of this term, see al-Iryānī (1996: 172-174).
} 
and of round shape and which the woman puts on her head in order to securely carry a pot (qidr or qașaș) holding a meal, protecting her from its heat, and for carrying a bundle of firewood without fear that it will fall off of her head. Similar to that is the tuhwäfa. The woman binds a strap (nitāa or rumma) around the side of it to bundle up the firewood, but it is only milhiqa when it is a relative of the plowman.

This is one of the memories which is attached in my mind with the village of al-Dhārī and is connected to the social customs which are current in general among the peasants and farmers of Yemen.

As an example, when the peasant or farmer is a sharecropper, he wakes up early to perform the dawn prayer, then returns to feed his bulls and leisurely takes his breakfast, which is something dry, sour milk (haqīn) or something else. Then he carries his plow (hirātha), which will be used later, by himself, or on a donkey prepared for that or as a helper. He goes to the field to plow and till it in furrows, the term for a furrow (shaqq) being tilm, ${ }^{69}$ even if it takes into the afternoon. This is when the woman (milhiqa) arrives, a meal on her head and in her hands some other things, like water or coffee. She gives it to him and if he has water, he washes his hands, but if not he rubs them with soft soil and blows on them. She will share the meal with him, if she has not already eaten. If she has eaten, she goes gathering firewood, collecting grass and fodder for the domestic animal, then returning respected for this, with the meal container on her head.

\footnotetext{
69 The term tilm is widely used in Yemen for a furrow; see al-Iryān̄i (1996: 97-104) for a lengthy discussion of this term and its use.
} 


\section{Nazīh Mu'ayyid al-‘Azm. Rihla fì bilād al-'Arabiyya al-Sa ‘ūdiyya. Second Edition. Cairo: Sharikat Dār al-Tanwīr li-al-Ṭibā'a wa-al-Nashr, 1986. Original, 1937.}

The Syrian journalist Nazīh al-Mu'ayyad al-'Azm visited Yemen four times, between 1927 and 1936, the last time being allowed by Imām Yahyā to visit and describe Ma'rib. ${ }^{70} \mathrm{He}$ provides a vivid description of Yemen during the late 1920s, including the Tihāma, his trip up to Șan 'ầ' and then south. He was able to meet and interview a number of Yemeni officials. He comments in several places on the agriculture he observed, but not with as much depth as al-Wāsi ' ${ }^{1}{ }^{71}{ }^{1}$ Born in 1890, Nazīh al-'Aẓm graduated from the American University of Beirut in 1913 and briefly served in the Ottoman army. In 1920, when Faisal reached Damascus, he returned to Syria from Egypt. He was an ardent nationalist working against the French occupation. When he returned to Cairo he met the American diplomat Charles Crane, who invited him to visit Hejaz and Yemen. In 1930 he returned to Syria, eventually taking up farming and dying in 1977.

Gardener of al-Rawda

[106] After departing from al-Rawḍa, I started off from where I was and I still remember this. I walked in a garden and a gardener came into view, so I went up to him and said to him, 'May your evening be happy, O uncle!.' 'God reward you with goodness and kindness.' I asked him who is in charge of al-Rawdia and what is his office? He responded that the one in charge is from San' $\bar{a}$ ' and he is the official of public welfare (ma'mūr al-a'āsha) in the court and he is responsible for taking care of guests, assuring their rest, food and drink. He takes to them the same things provided to his highness the Imam, making a visit to them everyday. Thus he talked with me. He knew how to weed out the strange plants which sprouted up between the lettuce (khass). I had not noticed that the tool he used for weeding was so very simple. I took it and turned it over in my hand and found that it is from the smiths in San' $\bar{a}$ '. The tool is long and cast in iron with a small wooden handle, nearly the length of the iron blade. They call this tool that they use mafris for digging holes, mud dams and everything in the garden. There is not among the other agricultural tools any better than the mafris. Their plow does not reach the length of the iron part, the plowshare (sikka) enters a few centimeters into the ground. Sometimes they make the plowshare from wood as a substitute for the iron. The great fertility of their soil allows them to produce a great deal by these innovative agricultural methods.

More than one of the people in the Jawf located a distance of some days to the east of Șan' $\bar{a}$ ' told me that there they never use plows and plowshares unless they know about them. Rather they take the cow to the field ( haql) and allow it to go back and forth several times. Then they throw their seed under its legs, where it is stepped on and planted in the ground. What is amazing is that they harvest from this simple crop a large amount of wheat and sorghum. Their yield, by the mudd measure, is no less than 50 mudd. ${ }^{72}$ One of the villagers from the Jawf told me that in their villages there was only one tool and it was used to dig graves for interring the dead.

\footnotetext{
${ }^{70}$ For a description of the author and his visit to Yemen, see Rossi (1940)a and http://www.almasalik.com/locationPassage.do?locationId=33091\&languageId=ar\&passageId=13880 (accessed November, 2017).

${ }^{71}$ At times he copies information from al-Wāsi'ī without acknowledgement, such as his discussion of trees in Wādi Ḥarīb (al-'Aẓm 1986: 340).

${ }^{72}$ I am not certain what the value of the mudd in the Jawf was, since it varies from place to place and over time. For Mecca, Mortel (1990: 180) defined the mudd as weighing between 1.8 and $2.2 \mathrm{~kg}$.
} 
I went through the garden accompanied by the gardener and saw many dry branches remaining on the trees. I noticed some of the trees, like quince, apple, peach, pomegranates with thick branches and small size fruit. But I also did not see many of the gardens of Șan'â' and the gardens of Wādī al-Qābil (which among them is like al-Ghūṭa among us). ${ }^{73}$ About an hour's car ride from San'ā', the cultivated trees resemble wild trees, due to the little care and lack of pruning branches which have no benefit. They let these grow in a natural way until the gardens become small groves, which can only be entered with difficulty. I asked some of the villagers [108] and farmers 'Why did you let your trees get to this state from little care?' They said, 'This is the custom which we became accustomed to since ancient times and we inherited, the father from the grandfather.' So I responded to them, 'You are making a mistake with what you do, since if you were to prune the trees by cutting off the dry branches which have no benefit and plant your trees apart from each other, trees will be large and grow well and be beneficial for you with yields better by far than the present yields.' They responded, 'By God, not one of us knew this before now and did not learn this agricultural method, but God willing we will try this method and perhaps it will be good.'

\section{Distribution of fruit and produce cultivation in $\operatorname{San}^{6} \overline{\mathrm{a}}$ '}

One of the nice things about Yemenis is that when they see a man more knowledgable about some things, he can give them some observations that are unfamiliar and that do not agree with their customs and they see the possibility of not defending their old views. They do not say 'no, our ways are better and we stand with our fathers and grandfathers and we can not possibly change', like others, but the opposite. They take to new views and try them out and if they find them better than their ways and customs, they follow them and do not reject them. They are clever by nature and know the difference between thin and fat.

Despite the lack of professional care of trees and despite being left in a state of neglect, they have excellent and appetising fruit. All of this is due to the fine quality of climate and excellent land. No doubt if they take professional care, there will be a big increase in their production. I saw in the garden of our abode several apricot trees grafted with plum (ijjās) and peach (durrā $q) .{ }^{74}$ This was many times in my thoughts, and even with Damascus being famous for its fruits, I never witnessed this in it, nor have I heard that apricot could be grafted with plum and peach, nor have I read in agricultural texts that these kinds of fruit trees can be grafted together. So I asked the gardener, 'Who guided you in grafting trees in this manner?' He responded that some of the Ottoman officials during the Ottoman government brought with them from a country they had entered, i.e. outside Yemen, various kinds of fruit trees, food crops $(t u \text { ' } \bar{u} m)^{75}$ and legumes (buqūl) and tried using them in Șan'a' ' and other parts of the country. Some of them were suitable for growth due to [109] the air and soil, blossomed and their planting then spread. Some of them were scorched by the Yemeni sun and died right away.

Ghayl Ālāf, Ghayl al-Aswad and the wells

Between our garden and the garden I went to I saw a small water channel (jadwal), which was the first water channel I saw in Șan'ā', so I asked the gardener about it. He told me this was

\footnotetext{
${ }^{73} \mathrm{Al}-$ Ghūta is a famous agricultural area near Damascus in Syria.

${ }^{74}$ The text reads $d h-r-\bar{a}-q$, which is either a printing error or a dialectical variant for the author.

${ }^{75}$ If the author is using Yemeni dialect here, the term ta am refers to cereal grains, but I suspect he means food crops in general.
} 
Ghayl Âlāf, the term ghayl meaning a flowing water channel (jadwal). There was little water in it now due to the little rain, but it increases a lot during the rainy season and irrigates most of the gardens of B'ir al-'Azab and the agricultural lands on the outskirts of San' $\bar{a}$ '. Its source is in the mountains a distance of several hours from Șan'ā'. There is another larger ghayl, called Ghayl al-Aswad, which passes through Bāb al-Sharāra and enters the garden of his majesty the Imam. Local inhabitants use the water for drinking and irrigating fields. This is also small in comparison with the water channels of Damascus. In truth there are no large water courses (anhär) in Yemen as the term nahr is understood. However, some of the water courses which resemble our water courses increase during the days of rain, proportional to the rainfall. During the rain period, great floods (suyūl) surge in the mountain ravines and Wādīs for hours or days and then lessen and dry out after the end of the rains. This was what led the Himyarites in ancient times to build dams $(s u d \bar{u} d)$ and large cisterns. I saw many dams in various places.

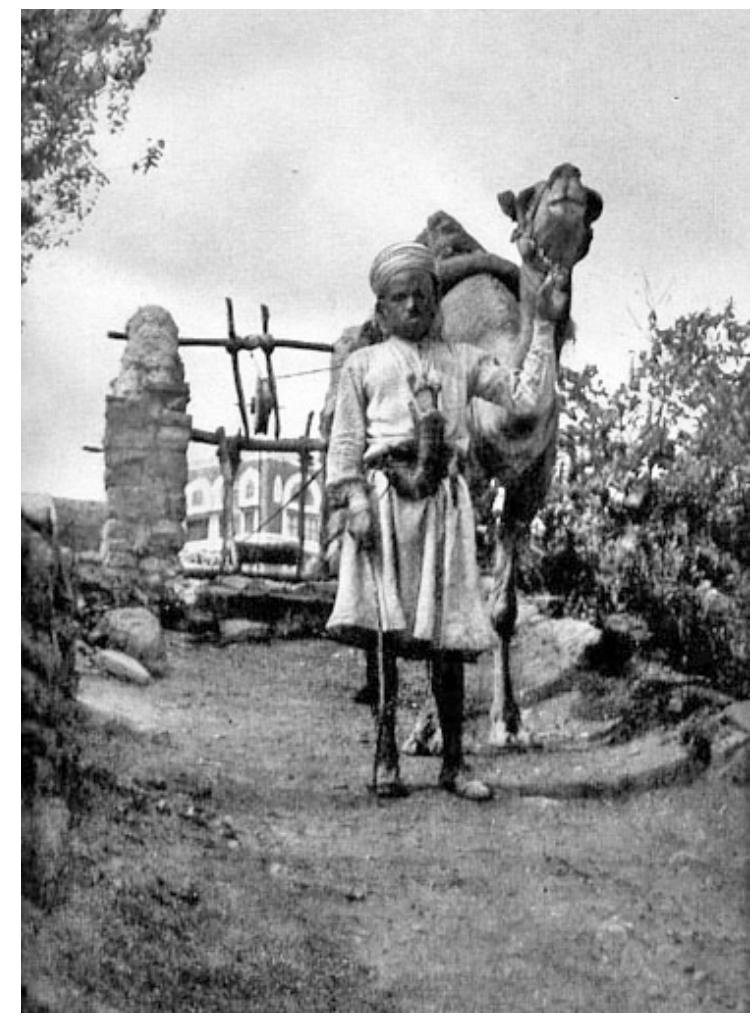

Inclined ramp of well in Șan' $\bar{a}^{‘}$; photography by Salvatore Aponti, 1930s

However, there is a lot of underground water present in Yemen at various depths, ranging from one to thirty or forty meters. In some mountain areas the depth reaches fifty or more meters. The evidence for this large amount of water is that I saw water from wells in various places, some close to others, coming from a type of soil the English call 'turf', rather than a rocky layer. These water sources $\left(y a n \bar{a} b \bar{l}^{c}\right)$ are near the ground surface and prove the abundant presence of water underground. Often these water sources are depleted if too many people withdraw their water, because the water leaks into the surrounding soil. Nevertheless, if one breaks through these soil layers until reaching solid rock, [111] then much water gushes out and that which is extracted is not exhausted. Those who work with wells and farmers in Yemen have done this until the present time. It is amazing that I did not see one well with water coming out of rock directly. Because of this, the wells are exhausted every day and then they wait until it fills a second time and then they return to it once more. 
We were asked many times to direct them to a method to increase the amount of water in their wells without having to dig down to the rock layer. We told them that perhaps if they were to dig a number of tunnels (aqbiya) next to the bottom of the well, the width of each not more than a quarter of a meter and the length a meter and half, this will guarantee an increase in your water sources. So some of them did this simple method and the water increased a lot.

al-Qādī Husayn al-Mutahhar and agriculture in Yemen

[231] On one of the days, as I was strolling through the Șan'à' sūq, I met with al-Qāḍi Husayn al-Mutahhar, who invited me to a visit with him in his house in Bi'r al-'Azab. Al-Qāḍi alMutahhar is one of the scribes in the service of the victorious one and close to his majesty, the Imam. His invitation to the house was very pleasing. He brought me to a room facing a garden fountain (shädurwān), i.e. nawāfir , and while we were talking it was apparent to me that he was an expert on agricultural matters. I saw an amount of the cotton that only grows in Egypt and America and asked him where [232] did he get this cotton from. He said it was a crop from Yemen and his majesty the Imam took an interest in it and imported a number of its seeds $($ budh $\bar{u} r)$ - and in Yemen the term for seed is $s \bar{l} b^{76}$ - from Egypt and America. This type of cotton succeeded well in the wādìs, the outlying low areas, al-Rawḍa, al-Jawf and other places. Thus, the Imam gave a major amount of seed to the farmers and peasants in order for them to expand the cultivation of cotton. A special cotton gin (mihlaj) was imported for ginning cotton and bundling it by the thousands. I recommended to one of the American businessmen (Mr. Holbridge) in Aden that he import new cotton gins from America. There is no doubt that the cultivation of cotton will flourish greatly in Yemen and bring excellent benefits to its people, if it is spread to all the regions, because the climate of Yemen, its air, heat, water sources and land, assists the success of cotton in every way. This is something worthy of a solution and an outcome so that they are not distracted in their thinking from this great agricultural resource.

[243] Present during my visit with al-Qādī Husayn Muṭahhar was one of the elite ${ }^{77}$ from the region of al-Jawf. He was an owner of a ghayl (i.e. a nahr) known as Ghayl al-Murād. He is called the noble Faysal ibn 'Alī Jār Allāh and he was introduced to me by al-Qāḍ̄ al-Husayn. I asked him about his region and its circumstances. He said: 'We thank God for the best, but our region is poor and we are poor people and ignorant, not knowing how to benefit from our land.' So I said to him, 'Learn from al-Qāḍi al-Muțahhar so that your land can be suitable for planting cotton and from the knowhow of superior planting of cotton. Why do they not increase its cultivation?' Then he added, saying 'We are poor people and do not possess the agricultural methods which would help us in developing the cultivation of cotton and other crops.' Then I asked al-Qāḍi al-Muṭahhar if it was true about this man's description and condition and if he was as poor as he declared. He responded to me, 'By no means is this man poor, since he owns a wide expanse of land and has servants, retainers, slave girls (jawār $\bar{\imath})$, horses and camels. He is like other tribal shaykhs, lazy and indeed very lazy, preferring to sleep than to make an effort at hard and productive work.' I suspect that al-Qāḍ̄ al-Muțahhar is correct in his complaint about the Bedouin princes and shaykhs, since on my third trip I observed very excellent parts of the

\footnotetext{
${ }^{76}$ As noted by al-Iryānī (1996: 569) everything that is sown, comes to life and produces is called șîb, including agricultural and wild plants, as well as human and animal semen.

${ }^{77}$ The text reads ahad al-shurafä', but he is described as a tribal shaykh and not a member of the Sāda class.
} 
Yemeni countryside and agricultural capability in everything, but, unfortunately, with a lack of crops due to the lethargy of Bedouin owners.

Out of affection for the benefit of Yemen and its people, here are some notes on agriculture, by way of example, for the sake of being concerned about the state and outcome. I say that the Tihāma, which is the well-known level plain adjacent to the Red Sea coast until the mountains, is suitable for planting varieties of date palms. There is much water underground at various depths and it is possible to extract and raise it to the ground surface by means of pneumatic pumps or mechanical motors. It is also suitable for varieties of sorghum and sesame. The foothills near the Tihāma and extending north to south for 100 kilometers are suitable overall with an emphasis on oranges (burtuqāl), sour and sweet lemons, citron (kabbād), and sweet orange (nāranj), as well as all kinds of citrus trees. In some areas I observed some of these trees growing without care from anyone. The mountains and the upper wādīs are suitable for planting mango (al-mankü), banana and all kinds of timber trees like oak (sindiyān) and others. [244] This, except for coffee, is what is planted here. But coffee is planted in large quantities in many places. Planting is suitable in the plains and highlands (plateau) above the mountain range facing the Tihāma and in the true Yemeni land surface for all types of flowering trees, cotton, flax and hemp (qunnab). One time I took with me some hemp seed from Damascus and planted it in a field of al-Sāfiya near Șan'ā' and it grew to an amazing extent. However, some of the people told his majesty the Imam that hashish was made from hemp, so the Imam ordered that it not be grown. I also planted various kinds of flax seed in a field in al-Săfiya and it grew to an amazing extent, but many locusts came that year and consumed it all. What is amazing abut Yemen is that they are not worried about or afraid of the coming of the locusts. ${ }^{78}$ One day I saw them go out a long distance from Șan'ầ' where the locusts were attacking agricultural crops and they collected them in large quantities and brought them back to Șan' $\bar{a}$ ' with joy and happiness. When I saw them in this state, I said 'Are you happy when the locusts are eating up your crops?' They responded, 'We are happy with this because the locust may eat our crops but we eat them and store them away in our houses from year to year.'

The planting of rice is suitable in the plain of Jahrān, which is about 30 kilometers from Șan' $\bar{a}$ ', [245] just as the planting of rice is suitable in the fields of al-Jawf and other areas with plentiful water. Unfortunately, the Yemenis are not interested, despite the efforts of their Imam and their government, to upgrade their agriculture with the kind of sufficient attention that would return huge profits. Although Yemen is one of the most fertile countries in the world, it lacks only science and diligence. His majesty the Imam exerts excellent effort in upgrading the agriculture, but it is also incumbent on the people to support their Imam and their government to arrive at the benefit called for. Cultivation of tobacco (tutun wa-tunba $\bar{a}$ ) is suitable in most localities of Yemen. I observed some of the poor types of tobacco planted in some parts, but these can be widely circulated and bring about a great benefit because the Yemenis use these two types of tobacco to a great extent and import a very large amount. Were they to import seeds from Persia and Turkey and spread their cultivation, they will be nearly exporting rather than importing tobacco, and thus serve themselves and their country with an important service and will not need the other, as is the case in every country of the world.

\footnotetext{
${ }^{78}$ Qāḍ̄ Muhammad al-Akwa' (1979: 114), on the other hand, viewed the damage caused by locusts on cultivated and natural plants an overwhelming disaster (tāmma); he provides a lengthy discussion of their impact, their collection, talismans written to keep them away and even how to cook them.
} 


\section{Ettore Rossi, "Note sull'irrigazione, l'agricoltura e le stagioni nel Yemen." Oriento Moderno 33(8-9): 349-361, 1953}

The Italian orientalist Ettore Rossi visited Yemen in 1936-37 and wrote the first grammar of Șan'ānī dialect. ${ }^{79}$ His article is divided into four parts: (1) irrigation systems, looking at wells, watercourses and perennial canals, distribution systems and utilisation of rain water; (2) water and irrigation in popular proverbs and customary law; (3) vocabulary relative to water and agriculture; and (4) the seasons. His work is especially valuable because it is based on field observation around Șan'âa' and the text is accompanied with eight photographs of water systems, irrigation and agriculture. ${ }^{80}$

Rossi begins his discussion of irrigation systems by noting that Imam Yahyā had personally commissioned a Polish engineer who came to Yemen in 1937-38 and bored an artesian well on the slope of Jabal Nuqum. Three types of irrigation systems are listed: raising of well water with animal power; utilisation of a few channels and perennial water courses known as ghayl; and, limited and inefficient utilisation of rainwater and from cisterns and through small dams (i.e., sadd, sg.) now in ruins. He further notes that the use of water varies from place to place, as does the vocabulary, some of which extends back to earlier South Arabic. ${ }^{81}$ The focus throughout his article is on the dialect terms used, but also includes descriptive detail.

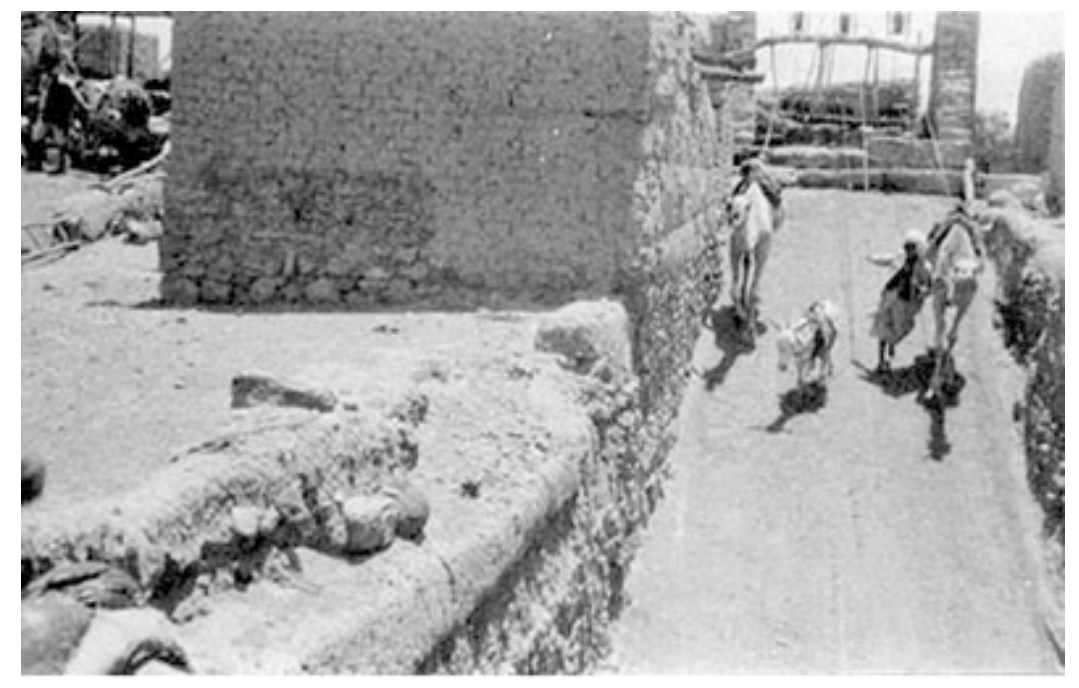

Inclined ramp of well in Șan'ā'; photography by Rossi in the late 1930s.

The basic term recorded for the well in Arabic for Șa'da was $b \bar{\imath} r$ (abyār and biyār, plurals) but with a plural of $b \bar{u} r$ in Dhahbān, northwest of Șan'ā'. In the arid coastal region of the Tihāma the term hasī is used for a well. In Șan'ā', however, the precise term used for the well is masna (masān̄, plural) with sānn for the one drawing the water from the well. The common form of the well is circular with a diameter of one to two meters, lined with stones on the inside. For

\footnotetext{
${ }^{79}$ Rossi (1939). This texts contains terms and proverbs associated with agriculture. In addition to his 1953 article discussed here, he recorded Yemeni terms in several other publications. For more Yemeni terms on agriculture and livestock raising, see also Lambardi (1950).

${ }^{80}$ The description below is a loose rather than a literal translation in order to provide the details from his personal observations and dialect study. I transliterate the terms here according to the system used in this article rather than the system used by Rossi. It is important to note that in Șan'a' and north the Arabic $q \bar{a} f$ is pronounced as $g \bar{a} f$.

${ }^{81}$ See Rossi (1940). For an up-to-date assessment of irrigation in ancient South Arabia, see Harrower 2016 and Maraqten 2017.
} 
extracting the well water a superstructure is necessary. This consists of a vertical wall (sawra; sawā'ir, pl.) for use of a large pulley ('ajala) and small winch (ja'īr) using horizontal ('arār) and vertical (sulākh) beams. The axis of the pulley is called mahwar, while the cord (habl) has a bucket or leather bag attached and is usually pulled by camels, or sometimes cows and donkeys. ${ }^{82}$ These go up and down a walking path called marnā in Șan'ā' and nearby areas and

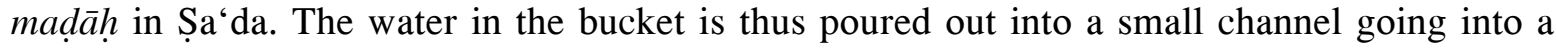
cistern (barik), where it is distributed to gardens by water channels ( $\operatorname{a} \bar{q} q \bar{l}, \operatorname{saw} \bar{a} q \bar{l})$. To the east of Șan'ā' he reports that the verb dala is used for drawing water and the well is called madlā. In Șan'â' he also saw small wells with the water pulled out by hand; this kind of well was called a manza 'a. In Dhamār and Radā' the goatskin used for the water is called dali and the inclined path for the animal is majlab (majālīb, pl.).

In explaining the usage of sana for the action of drawing water from a well, Rossi quotes a zāmil lyric from the Balhārith:

naḥnu Banī al-Hārith wa-law sanaynā

wa-ihnā' rijāl al-harb idhā 'ādaynā

We are the Banī Hārith, and even when we are drawing water

we are men of war ready to attack.

He also records a song from a man drawing water from a well in San' $\bar{a}$ '.

Regarding irrigation through perennial watercourses, Rossi observed that they were always quite small and derived from springs at the bottom of mountains and led into a major channel (sāqiya, jāl) covered (masqūf) with stone for long distances. ${ }^{83}$ The term for this type of channel is ghayl (ghuyūl, pl.). At some point most will fill into a cistern or basin called ma'jil or mäjil), from which the water will be distributed. The examples Rossi gives include those in Bayt Ma'yād, southwest of Șan'ā' on the way to Hadda, in Șan'à', Hadda and the small village of 'Așur to the west of Șan'à'. These cisterns vary in size and depth. They are usually circular or rectangular with a perimeter up to a hundred meters that may be surrounded by a wall (hâjiz, safiff, swār ). The water that arrives in the main channel (sāqiya) enters through a passage called darrāba. When the cistern is full, the stone (nāṣiḩi) blocking an outflow passage at the top is removed so that any excess water can flow out. The verb used for the flowing out is ansaha. The water used for irrigating fields is drained through a hole (mijalli, mabāh, füra manjūla) located at the bottom of the cistern. The hole near the bottom is opened and closed by using a large wooden beam (khashaba).

The water master who manages the distribution is called $d \bar{a}$ 'ilì. He regulates the time or amount of water in a share with different systems. ${ }^{84}$ Rossi describes this for thirteen different locations he observed, as follows:

(1) Southwest of Șan' $\bar{a}$ ' the water master uses a marking pole ('alam) divided into 24 palm lengths (kaff; kufüf, pl.). The water is then allocated according to the share (fard; furü, , pl.) of individual farmers. For eight hours during the night there is no allocation, while the overflow from the upper part of the cistern flows into an underlying one. In this location the master

\footnotetext{
${ }^{82}$ Al-'Azm (1986: 102-103) observed this kind of system in San'ā’ in 1927.

${ }^{83}$ This type of covered channel is usually known in the literature as a qanāt or falaj in Oman. There are a few of these in Yemen, and many of these systems are centuries old.

${ }^{84}$ For a description of the role of the $d \bar{a}$ 'il, see 'Aslān (2000: 60).
} 
distributes water according to the shadow $(f \bar{a} y a)$ that the sun projects on a nearby wall, when that is available.

(2) In Hadda, an area rich in water and plants to the southwest of Șan' $\bar{a}$ ', the water share is called mafra' (mafāri', pl.) and allocation is made by using a pole ('üd̄ or 'alam) which is submerged in the cistern and measured by the sun's shadow of a wall (jidr or 'alam) oriented north/south. On average, every twelve hours defines a fard, which is divided into 60 parts (mafāri'), each consisting of about 12 minutes of water supply. In the morning the first nine segments are determined by the time elapsed between sunrise over a mountain to the west and the time when the wall's shadow from the sun reaches a specific point marked on the ground. The measuring proceeds until the sun reaches its zenith and there is no shadow projected. In the afternoon the 30 remaining shares are measured by the shadow projected to the east of the wall. A second wall with other marks on the ground is used to calculate the time in winter when the sun rises and travels in the other direction.

One farmer told Rossi his total water allotment each hijrī month was 30 parts with ten mafäri ${ }^{85}$ on the 4th, 15 th and 28th days of the month. The exact amount of water per share would vary, depending on the flow from the cistern. The whole irrigation process in Hadda takes a large part of the farmer's day, since he needs to prepare and maintain the channels going to his fields, as well as be present when the water master shouts the name of the next shareholder to come and take out (yaqlab al-mä') his share of water. The farmer would then respond from the valley below.

(3) In the plain of Shu'ūb, immediately to the north of San'à', the extent of a fard share at Ghayl al-Aswad is 24 hours, with a half share (nuș fard) of 12 hours, quarter share (rub' fard) of 4 hours, 8th share (thumun fard) of 3 hours, 16th share (nuṣs thumun) of 1 hour and 1/32 share (rub' thumun) of 15 minutes. ${ }^{86}$ Time measurement is made by use of a copper cup called a țâsa (țịsān, pl.), which has a hole of a given size as serves as a water clock. ${ }^{87}$ Here a measure of 16 țạsa is equal to three hours (an eighth of a fard share), so that each țạșa has a duration of 11 minutes, 15 seconds. Each 24-hour period thus would equal 128 țạsa measures.

Rossi notes that the țạsa is not used in cases of water disputes or when there is an alternate form of measurement, such as the use of shadow lengths in Hadda. The water master, who is subordinate to the official known as a wakil, is responsible for the allocation of ghayl water. Each day he calculates the height and position (manzala; manazil, plural) of the sun. About three hours after sunrise, the master calculates the time in a manzala, each one of which equals $1 / 32$ of a fard share or four tạs $\bar{a} .^{88}$ From this time on the water master adjusts the time using his body as a gnomon for the shadow it projects on a fixed set of markers on the ground, as measured by each step (qadam). At the third hour after sunrise his shadow is equal to 8 steps. For the third to the ninth hour each step equals two țassa (i.e., 22 minutes and 30 seconds); from the ninth to the tenth hour each step is one țāsa and after the tenth hour each step and a half is a țạsa. At Shu'ūb a complete cycle (dawla) is renewed every 18 days, each day equaling one fard of 24 hours.

\footnotetext{
${ }^{85}$ This term is derived from South Arabic ('Aslān 2000: 58).

${ }^{86}$ The history of Ghayl al-Aswad, which was first dug in 803/1400, is provided by 'Aslān (2000: 83-89).

${ }^{87}$ See 'Aslān (2000: 55) for a description of the țāsa in Șan'ā'.

${ }^{88}$ There seems to be an error here, since a țâsa is said to be only about 12 minutes and 1/32 of a fard is 15 minutes.
} 
When there is no daylight, the water master uses a modern mechanical method. Each hour is heralded for the walled city of San' ${ }^{\prime}$ ' by a trumpet $(b \bar{u} r \bar{\imath})$, announcing it from a tower (nūba). This is the hour coming from the wakill. In case of a dispute, the time measurement of the tạsa is used. Since it is made from copper, the hole at the bottom is precise. In Shu'ūb the țâsa has a liquid capacity of two rațl. ${ }^{89}$ When the tạșa is emptied (tanjaha or tfarragha), it is filled up again with water. During the night, time can be measured by the moon's shadow as the stars rise and set. The water master follows the paths of the following stars: Canopus (suhayl), Sirius ('alab), the Pleiades (thurayyā), a star in Orion (sulm or așlam), a star in Taurus (thawr), Venus (zahra), a star in Ursa Major (na'sh al-nabi) $)^{90}$

(4) In Wādī al-Dilā', northwest of Șan'ā', water is distributed by the fard, as in Shu 'ūb, with the fard equal to the twelve hours following sunrise until sunset, and each specific share is called a dawl. During the day measurement is made by shadow lengths and at night by stars. In both cases it is an approximate measure ('alā ghālib z̧ann).

(5) For Wādī Zahr, northwest of Șan'ā', the ghayl now called Wādī Zahr used to be known as Ghayl 'Isāwī. It descends from Bayt Na'ām and has a special allocation regime. The water is used for 15 days by the village of Qaryat al-Qābil, now also called Rawḍ, then for 10 days for the villages along the wādī and 5 days for the village of Bayt Na'ām. When the cycle is filled

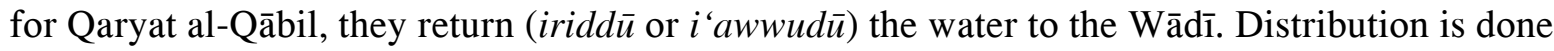
here with the tạsa, but in a particular way. A small, bowl-shaped țăsa, which has a hole underneath, is placed in a large one full of water. The smaller one floats initially, but then fills and sinks (tuqmis) to the bottom. On the morning of April 22, 1937, I saw a water master on a stone slab with the large and small țạsa bowls, and with the inseparable waterpipe (madā'a), as the ghayl water was flowing out to the lush garden plots. In Wādī Zahr one hour is equal to ten țăsa and a fard equals 24 hours of flow. The tạs $a$ measure regulates each specific share term, called a makill. When the turn is for someone, the water master calls out his name, saying almakīl 'alayk.

(6) At Masājid, three hours west of Șān'ā' on the way to Sūq al-Khamīs, there is a ghayl of greenish color water on a hill at the foot of the village. The water is distributed by a water master (mudawwil) using a 12-hour fard, but this is an approximate system.

(7) At Bayt Ghawbar, a village northeast of Sūq al-Khamīs, the ghayl flows into a cistern $(m \overline{a j i l})$, from which it is distributed by a local official who has the exact name of every time slot (sanīb or mustanib). The dawill is the person who does the actual work of irrigation. He submerges the marker pole ('alam) into the cistern. The point at which the water flows in is called muradd, and the place where it flows out is called khalla '. The process of releasing and blocking the water flow is made with a wooden beam (khashaba). The amount of water is measured by the palm length (shibr) on the marker, which is approximate.

(8) In Sanhāan, to the east of Șan'ā', the turn is called dawl and the one irrigating is the mudawwul. The flow of water for 24 hours, day and night, is called sadda.

(9) In Sa'da in northern Yemen, the water is distributed by the local governor, called 'ámil.

\footnotetext{
${ }^{89}$ The ratl in Yemen varies according to place and the type of measure. It is generally around 560 grams; see Table 1.

${ }^{90}$ For details on local star names in Yemen, see Varisco (1993). Rossi does not provide sufficient information to clarify which stars were used. For time-telling at night, rather than stars as marking seasonal times, the system of 28 lunar mansions was used.
} 
(10) In Wādī Sirr, east of Șan'ā', the water is measure with a țạsa by the local water master (ma'mūr al-mā').

(11) At Radā' and Dhamār the ghayl water is distributed by the time measured in feet (aqdām) in relation to the position of the sun, the fard being for 24 hours. The one distributing the water is called duwīl. In Dhamār the water outlet from the cistern is called makhlūla, but füra in Radā'.

(12) At Shahdī, the water master ( $d \bar{a}$ ' $i l)$ distributes each turn for water with a stick (wathan), engraved with marks, that is submerged in the cistern.

(13) At Qaryat al-Ghayl in the Jawf water is distributed by the sarrāf and calculated by the qīrāt (qarāriț, pl.), a measure of time equal to a half hour. The method of time measurement is by shadow length and the use of stars. When it is cloudy, the sarräf regulates the time according to his conscience ('alä dhimmata). He is paid a qürāt share for his service.

The distribution of ghayl water and the information regulating its use are recorded in special documents or notaries. The registration log for the Hadda ghayl is with Sayyid 'Alī al-Mutā' of Șan'ā’; for Ghayl al-Aswad in Shu'ūb it is with a certain al-Razzaqī in San'ā'. In Wādī (Zahr) the secretary $(k \bar{a} t i b)$ is al-Tijāni. The one who does not want to utilise a turn of water can sell it to someone else. The right to a share of water from the ghayl is not necessarily linked to the land, but can be sold separately.

In 1936 the perpetual right to a țạsa (11 minutes and 15 seconds of irrigation every 18 days) would be for 90 riyals; a single fard of 24 hours of irrigation was for 28 riyals.

The ghayl is sometimes endowed as waqf for a mosque or pious institution (such as 'Așur to the west of Șan'a'’). Most often, however, the shares are owned by farmers of a given area of irrigated land or members participating in a set of shares. In Șan'ā' the land which has a given water share is called gharim.

The water master $\left(d \bar{a}^{\prime} i l \bar{l}\right)$ is paid by the landowner in cash or produce. When lucerne (qadhb) or cereals are sold, a tenth of the price is distributed between the wakil and the water master. This is the case for Shu' $\bar{u} b$, where the wakil has eight days less than the water master. The wakil records (yahsub) the ghayl register and divides (yisubb) the land into plots, while the water master only distributes the water. The wakil is also entitled to two fard (every 18 days); this is called raqabat min ra's al-ghayl and the wakil may sell this, using the proceeds to compensate the ones who clean the ghayl system (i.e., tandiffatt).

In Wādī Zahr I heard about punishments ('adhāb) for those who open (yifjir) the flow of a ghayl or a distribution canal out of turn. The offender must pay two riyals, one of which goes to treasury (bayt al-māl) and the other to the ghayl system itself.

The ghayl system is usually covered, especially if there is a long distance to the irrigated fields. For example, Ghayl al-Aswad is covered up to the southern wall of San' $\bar{a}$ ' and through the city. In the vicinity of the Imam's palace (maquam), there is an opening where the inhabitants can draw water. It then leaves through the northern wall of San' $\bar{a}$ ' and flows to the Shu'ūb fields, in which are channels lined with plants, bushes and roses, until they flow out to the north about a meter in width and half a meter in depth.

In Ghayl al-Șāfiya, to the northwest of Șan'ā' and towards Shamla, Rossi noticed openings in the covered ghayl. These are called kada'im (kadama, sg.) and are used for digging down 
into the channel and cleaning the bottom from sediment and stones. The bulkhead over the opening is called masrī (masār, pl.). ${ }^{91}$

The source of the ghayl, which is often surrounded by legends and mystery, is called ma 'ya$n a$ (ma' $\bar{a} y i n, \mathrm{pl}$.), but this same term in 'Ușāb refers to a small watercourse. In the area of Ray-

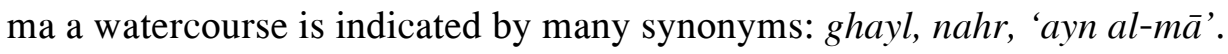

Rossi provides a final list of other ghayl sysems. An area rich in such systems is Wādī Dilā', to the northwest of San'à'. The seven systems mentioned to Rossi include al-Sabara, alMasbīḥa, 'Ambarūd, Ghayl al-Dawla, al-Ṣāfiyān, al-Raysha and Ghayl Ḥaqq al-Shāri'. Other names that he heard about include: Șarada (a valley in the Manākha region), 'Awman (a wādī in Manākha on the way to Maḍār), al-Jibin (irrigated cultivation of coffee in Manākha), and Ghayl al-Kharid (a place in Arḥab). Near Manākha, at the end of the town towards the west, there is a ghayl used by the town. An iron grid, erected by a Turkish pasha in 1326 (19081909), protects the cistern.

The Utilisation of Rainwater. Rainwater was used in the past for irrigation involving dams and reservoirs. The ruins of ancient hydraulic works can be found in many valleys and the notices in al-Hamdān̄̄'s books al-Iklīl and Sifat jazīrat al-'Arab are valuable in this regard. Someone from 'Ușāb told him that they deflect the flood water (sayl) with wood (' $\bar{u} d \bar{l} ; a w$ ' $\bar{a} d$ ) and stone barriers. The main offtake channel is called a mashrab (mashārib, pl.) and the dam or barrier is marzam (marāzim, plural) or maksaf (makāsif, pl.). To protect the flood land, they construct small walls, which in Manākha is called a maradda.

The system north of Șan'à' towards 'Amrān uses flood water (sayl), as explained in an interesting note by Goitein. ${ }^{92}$ The secondary channels (sirar; assirra, pl.; or salīl; silwal, pl.) are blocked with a small dam (mașraf; mașārif, pl., or mazaff; mazaffāt, pl., or harra to the west), constructed of stone, soil and grass $(z \bar{l} l)$. This forms an impenetrable barrier, so that the stored water first irrigates the upstream field and then descends to fields below when part of the barrier is removed. During the irrigation from the floodwater, the farmers warn each other by shooting rifles and shouting. There is someone who guards (harasa) the barrier.

Water and irrigation in popular proverbs and canon law

The importance of water and its use from rain and perennial sources is reflected in Yemen, as in all Arab countries, in proverbs and other types of expression. Regarding the ghayl for irrigation in Wādī Zahr, it is said "The ghayl of Bayt Na'ām irrigates beyond their own people" (ghayl Bayt Na'ām yisqī li-ghayr ahlah). This is because most of the water descending from Bayt Na'ām benefits the fields of Wādī Zahr. The same is said for Ghayl 'Alāf ("The ghayl of Wādī "Alāf irrigates beyond their own people," ghayl Ghayl 'Alāf yisqī li-ghayr ahlah ${ }^{93}$ since this ghayl stems from Bayt Baws to the south of San'a' ${ }^{\prime}$ ' and above Hadda and descends to Șan'â' crossing the garden district of Bi'r al-'Azab until it ends up in the fields of al-Șāfiya. They also say: the ghayl of a neighbor and shameful famine (ghayl sarrah $w a-j \bar{u}$ ' fadda). ${ }^{94}$

In Islamic legal works (fiqh) there is a tithe on agricultural produce, with differences noted for fields watered by rain, flowing watercourse and perennial sources versus fields irrigated with

\footnotetext{
${ }^{91}$ Rossi (1953: 356) suggests that this term is related to a South Arabic term recorded by Rossini in his Chrestomathia (Glossario, p. 179).

${ }^{92}$ Rossi footnotes the index in Goitein (1934) for Regen and Wasser.

${ }^{93}$ This saying is also recorded in al-Akwa' (1984(2): 758).

${ }^{94}$ See al-Akwa' (1985(2): 758).
} 
greater effort, such as wells or hydraulic pumps. The latter, such as the well (masnā) are normally subject to a twentieth rather than a tenth as the tithe. In Yemen the tithe ('ushr, commonly known as zakāt) is paid to the treasury (bayt al-māl), which is represented by a trustee (ma'mūn), who keeps a record of the assessments and payments in a special register (qudfa).

The theoretical discussion of this material in Yemen is found in the classical Zaydi legal work known as Kitāb al-Azhar of Imām al-Mahdī and the commentary al-Ghayth al-midrār, edited in four volumes in Cairo. ${ }^{95}$ In the third volume there is a treatise on shuf' $a$ (the right of preemption) by 'Abd Allāh ibn Muhsin al-Haymī. This covers everything related to the courses of water (majāri al-mā'), water channels (anhar), floodwater (suyūl), wells $(b \bar{u} r)$ and slope runoff (sabābāt al-jibāl) with schematic drawings and vocabulary relating to irrigation, such as field (jirba), cistern or reservoir (ma'jil), channel (sāqiya), mill (rah̄ā), channel opening (manshara; manāshir, pl.), field bund ('arim), etc.

Vocabulary relative to water and irrigation

In addition to the vocabulary referred to in his previous pages, Rossi provides a list of other Yemeni terms for water and agriculture. Although some are from Șan'ā' or found throughout Yemen, he also describes terms for specific locations. These include:

- 'āra ('awā'ir, pl.): bund for channel (Wādī Zahr) and small partition in a field (Masājid and Mafhaq)

- 'árida ('arwām or 'irwām, pl.): bund in a small water channel made of soil and stones to divert water

- $b \bar{a} h \bar{\imath}:$ riverbank of a ghayl or land cultivated near the riverbank of a canal (Jawf)

- fāniya: canal (Zabīd)

- jaḥra: small sunken Wādī (Harāz)

- jarf: cave or shore of a wādī (Zabīd and Jawf)

- qafada: barrage for ghayl (Hadda)

- qalūba: action of lifting the stone that blocks flow in a channel in order for the water to flow to flow and irrigate a field

- harra: terrace wall

- kharaza: stone in the middle of a basin $(\text { marjaw })^{96}$ separating the water from one side to the other.

- maqlab: place where water is diverted from the channel to the field

- manfas: opening in a channel or in the wall of a building

- manshara (manāshir, pl.): stone placed against the openings in the retaining walls of a field to prevent the influx of water

- mazamm: bridge over a watercourse; in Wādī Zahr it is the hole in the wall enclosing a field

- nafas: hole in the wall surrounding a field for regulating the influx of water (Jawf)

- 'aqla: $:^{97}$ basin in which the water from a flood rests

- sayl or sayla: seasonal flood

\footnotetext{
95 Ibn Miftāh (1938).

96 Al-Iryānī (1996: 343) defines this as the basin (hayḍ) in which the water from a well bucket or skin spills.

${ }^{97}$ Al-Iryānī (1996: 643) describes 'uqla as a dirt hole in the ground which collects water. It is not a cistern (birka or ma'jil), nor a type of cistern for collecting water known as kariff, nor a dam (sadd).
} 
- sawm or süm: bank of a channel (Harīb)

- shaghara: small derivation canal (Wādī Zahr)

- thaqb: $:^{98}$ hole or subterranean channel.

The land cultivated in the Șan'ā' area is called $m \bar{a} l$, a cultivated and irrigated field is a jirba (jirāb, plural) and subdivided into plots called qasam. A Șan'ānī proverb states: "Better the gleaning of a field than the harvest of a plot" (qumān jirba wa-lā zara 'qasam). This is called shubar or harra in Jabal Hufāsh, sabba at Masājid and 'ūbr in the Arḥab region. In Șan'ā' the fields are measured by the labna ${ }^{99}$ (elsewhere called a habla or shakla). In the Jawf the habla measures 10 ells. The labna in the Arhab area is 10 square ells, corresponding to $71 / 2$ wa' $r$ ( $a^{\prime} w \bar{a} r, \mathrm{pl}$.), which has a broader length about half the stature of a normal man measured from the tip of the fingers of a hand across his chest.

The ground is plowed with camels or oxen and rarely with donkeys. The plow in the highlands is called hali (halā', pl.). ${ }^{100}$ The tip of the plowshare is the sinn, the beam supporting the plowshare is tajr (atjār, plural), halaq is the upper part, dafla the handle, qadim for the axis that binds the yoke together, hijj for the yoke, and simaj for the wood that holds the yoke on the animal's back. The plow has other names in different regions: 'adā (Rayma), sāqa (Hajaila), nibāl (Yarīm), sabb (Habbāt) and hadid ('Attāra).

Other terms relative to plowing and agricultural work include:

- batūl: farmer

- madmad: yoke

- damd or dāmida: pair of oxen

- mawthab: wedge that holds the parts of the plow together or the string attached to the feet of an animal (Jawf)

- makhyas: a type of hoe for removing the soil from the plowshare; the action is called khayyasa

- 'aqar: rainfed land without irrigation

- kawbal: pile of soil• harra: land, field, bund that holds in the earth and filters the water to the fields

- $q \bar{a}^{\prime} a$ : plain

- madar: mud, a potter is a maddār

- mawjir: land cultivated for from a channel (Jawf)

- șulbĩ: uncultivated land

- tịn: desert or hard ground (Jawf)

- wathan (awthān, pl.): stones piled up as a field marker, also on graves. In the Khuzayma cemetery in Șan'à' two stones are used on the graves of a woman and one on that of a man. In the Tihāma two stones are used for men and three for women.

- wadn (awdān, pl.): a field or a plot of land for the cultivation of coffee ('Usāa).

The Seasons

The citizens of Șan'ầ' commonly distinguish four seasons: spring ( $\left.r a b \bar{\imath}^{`}\right)$, summer (sayf), autumn (kharīf), winter (shitā'). Fruits are called mukharrafāt, since they are especially ripe in the fall.

\footnotetext{
${ }^{98}$ Rossi reports thaghb, which may be a dialectical variant, but the Arabic term is thaqb.

99 The more common form in Yemen is lubna or libna; see al-Iryān̄i (1996: 796).

${ }^{100}$ For Yemeni vocabulary relating to plow cultivation, see Varisco (2004).
} 
There are particular terms in the countryside that Rossi could only pick up incompletely. In

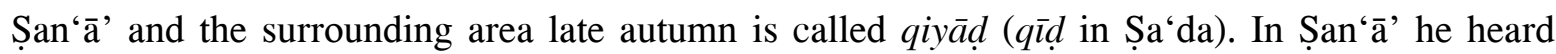
about an extreme cold called wuqūf in December and January, starting December 21 (Kānūn alAwwal 9); this period is also called the days of the months of Kānūn (ayyām al-Kāwāninn).

In Wādī Zahr they distinguish the beginning of winter with rain as 'allān $n^{101}$ separate from true winter (shita '), followed by the spring season as sayf, a dry period of two months in summer called jahr and autumn (kharîf). Near Banī Ismā'îl to the north of Manākha the harvest season is called 'allān in the valleys and khāmis ${ }^{102}$ in lower areas.

The short period of summer rains in Șan'ā' is called mațar al-ṣayf. The longer period of autumn rains is called matar al-khariff, which produce the most rain.

When it rains the children celebrate and sing:

"yā karìm

là khallat lā jirba wa-lā ‘arìm."

"O generous God

nothing is empty, no field and no field bund."

Rossi records a song used to ask for rain: ${ }^{103}$

"yā mațar wa-imtar

wa-al-sha'ìr wa-al-birr

wa-al-dharā' ${ }^{104}$ tukbar

fi juba al-manzar

hannat ru' $\bar{u} d$ 'Āli

hannat 'alā al-jibāl(i)

nasqī bih al-wațan( $i)$

yā Allāh bi-ghayth al-hanīn

nasqī bih al-wațan(i)."

"O rain, do rain

so the barley and wheat

and sorghum will accumulate

on the scenic terrace.

The high thunder ringing out,

ringing out on the mountains,

so we can irrigate by this the homeland.

Oh God with the longed for plentiful rain

we irrigate by this the homeland."

The harvest season, as well as the harvest itself is called $\operatorname{sara} b^{105}$ or thamara; the return from the fields after the harvest is called rawīh.

\footnotetext{
${ }^{101}$ Rossi (1939: 151) mistakingly has 'allām (!) for this rain period.

102 Rossi (1953: 360) writes kāmis, but the reference is to the rising of the fifth (khämis) star of Ursa Major (banāt na'sh). According to the Yemeni agricultural marker system, khāmis is a period of 14 days in September (Aylül 3-16) in the Julian reckoning (Varisco 1993: 127). The common term for the harvest of grain in Yemen is surāb and in the mountains generally occurs in October and November (al-Akwa 1979: 116).

${ }^{103}$ Rossi (1953: 360) records this in dialect, but I provide the formal Arabic terms.

${ }^{104} \mathrm{I}$ interpret this as a reference to sorghum (dhura), the most common cereal crop at the time in Yemen.
} 


\section{Muhammad Ḥaydara, Takwīm. Ta'izz, 1945 [Translated by Serjeant (1954)]}

Yemen has a long history of agricultural almanacs, especially for the Rasulid period of the 13th-15th centuries C.E. ${ }^{106}$ The almanac of Haydara, translated by Serjeant, was composed in 1945 for then crown-prince Ahmad for official use. Haydara (1902-1973) was a scholar and astronomer; he started teaching in the first modern school in the Mutawakkilite Kingdom in Turba, near Ta'izz. Besides astronomical and agricultural information, the almanac contains a variety of lore common to the genre. Although it is arranged according to the hijri lunar calendar, this is correlated to the solar calendar and the risings of certain stars and asterisms. It is meant to be a general guide for farmers, but the compiler also notes: "Now, concerning the seasons of sowing (badhr) and harvesting (hișād), I am unable to include them all, on account

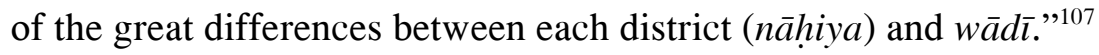

His almanac was still being published as late as 1394/1974, when it was called Tawāli ‘ al-

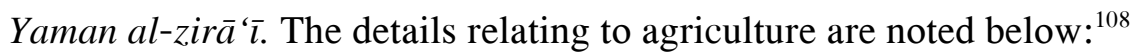

\section{January (Kānūn al-Thānī)}

1 Mustard (tartar) is planted.

5 The time is now suitable to plant madder (fuwwa).

14 The qiy $\bar{a} d$ [winter harvest] of white emmer wheat ('alas ) (rye). ${ }^{109}$

15 Grafting of vines.

16 Planting of sour pomegranate (a small sour green type).

17 The grain harvest (hiṣād) begins in Tihāma.

22 Trees are planted.

24 Sugarcane is cut.

25 Roses collected until Nīsān (April 14).

27 Small palms transplanted

28 Planting of figs ends.

29 The young vine shoot (gharisa) transplanted.

February (Shubāt)

7 Cotton and melons (bitțikh) planted.

11 Vines are planted.

12 From now, fruit-bearing trees are planted.

14 Qiyā $d$ harvest of wheat (burr), harvested till the end of Shubāt (March 13).

15 Sugarcane is planted.

17 Sesame (juljulān) is sown in Tihāma on the running spring (ghayl).

21 Sowing of grain in al-Rabādī and Hubaysh.

24 Sugarcane is planted.

28 Cabbage (lahāna), i.e. kurunb, is planted.

${ }^{105}$ In most of Yemen this is either șirāb or $s u r \bar{a} b$ and it usually relates to the autumn harvest of sorghum. In the Himyaritic calendar dhu șirāb refered to Tishrīn al-Awwal or October.

${ }^{106}$ See Varisco (1994) for a study of Rasulid agricultural almanacs.

${ }^{107}$ Serjeant (1954: 443).

${ }^{108}$ These are taken from Serjeant's article, although I use my standard transliteration, correct errors in Serjeant's translation and change the language at points to make the information clearer. Although I have not seen the original almanac translated by Serjeant, I have a copy of the one from 1394/1974, which has much of the same information.

${ }^{109}$ This is actually emmer wheat, also known as nusūl in Yemen, although Serjeant refers to it as rye. 
March $(\bar{A} d h \bar{a} r)$

1 Grapevines ('inab) are irrigated.

3 End of tree planting.

5 Pruning (taqlīm) of grapevine stocks.

12 Roses and flowers planted.

13 Grapes are abundant in some districts.

15 Indian banana (al-mawz al-Hind $\bar{l}$ ) planted.

16 Black cummin (habba sawdā') is sown in hot districts and taken after half a year.

21 Grain is winnowed at Ibb and Jibla and its district.

28 Red sorghum (dhura) sown, and harvested after seven months.

$\underline{\text { April }(N \bar{i} \bar{a} \bar{n})}$

6 Sowing of grain in al-Suhūl and Jibla, etc.

10 Trees in leaf.

14 Grain sown in the hot and temperate districts, and plucked after four months, and, in Tihāma, cowpea (dijr), etc. are plucked after 75 days.

17 Planting of the broad bean $(f \bar{u} l)$ is suitable in cold places, but it is unsuitable elsewhere; it is harvested after six months.

19 The beginning of coming down of the rains on the hill-slopes. Palm trees are fertilised.

24 The heavy rains on the hill-slopes begin, and the heat intensifies.

28 Planting of sorghum begins in al-Hujarīya at the end of the month.

30 Winnowing.

May (Ayyār)

5 The South Wind (janūb) blows, and the wādis expand and over-flow.

13 Fruit bunches and almonds become ripe.

14 Sowing of barley ( $s h a{ }^{\prime} \mathrm{i} r$ ) in some of the country.

20 Sowing of broomcorn millet (gharib) and bulrush millet (dukhn) in al-Hujarīya.

June (Hazīrānn)

2 Planting of bulrush millet in Tihāma and the hot districts.

3 The falling of the rains begins in the high ground, and the flowing of flood water (sayl) in Tihāma.

7 The hot winds (samä'im) commence, and the grapes turn black.

10 Rice is planted.

12 The ground splits open.

14 Sowing of gharb sorghum in hot districts.

15 Bulrush millet planted in the mountains.

24 Winnowing of wheat (burr) in Ibb from June 15-July 11.

28 Sowing of 'Arabi wheat (a small-eared Yemeni kind smaller than that found elsewhere) and barley.

29 Sowing of khashkhāsh (poppies) and müma (cotton seed). It is plucked after five months.

30 Close of the season of rain in the hill-slopes.

July (Tammūz)

8 Planting of bulrush millet in the hot and temperate districts.

9 Eleusine millet (kinib) and teff (tahaf) are planted and harvested after 70 days. 
15 Sowing of white emmer wheat ('alas), fenugreek (hilba), barley and lentils, which are plucked after three months.

17 Dates collected.

25 Planting of lucerne $(q a d b)$ is not suitable during the whole of the season of early autumn (kharîf); rain and cold are harmful to it.

August $(\bar{A} b)$

5 The flood water (sayl) is expected in Tihāma.

7 Carrots (jazar) and melon (bițtikh) planted.

9 Wheat reddens.

11 Grapes and figs become sweet.

13 All fruits ripen.

15 Plucking of fruits begins.

16 Planting of gharb sorghum in part of Tihāma.

17 Planting of sorghum in Zabīd and Rima'.

19 The flood water irrigates Tihāma.

24 Leaves of the trees change.

25 Quinces (safarjal) and pomegranates (rummān) abound.

27 Watermelons (habhab), garlic (thüm) and onions (baṣal) are planted.

29 White radish $($ fijl) is planted.

31 Cessation of rains in the mountains.

September $(A y l \bar{u} l)$

2 The flood water ceases in Tihāma.

4 Planting of baynī and hijna sorghum in Tihāma, as well as red and white (thālith $\bar{\imath}$ ) sorghum.

10 Ripe dates (rutab) and grapes abound.

15 Fruit trees planted in some of the sunny districts.

16 Time of planting and pruning grapevines.

17 Cucumbers (khiyār) are collected in the provinces and administrative district of Ta'izz.

18 Sour pomegranates, figs, and the prickly pear (al-balas al-Turkī or al-shawkī) are planted.

20 Grapes are plucked. The sap rises to the tops of trees.

21 Parched grain (jahissh al-hubūb) is present in the administrative province of Ta'izz.

23 The crows come to the fields.

25 Planting of khāmisì sorghum in Tihāma.

26 Quinces and pomegranates come to end.

28 Grain harvest in the districts of eastern Yemen (al-Mashriq).

October (Tishrin al-Awwal)

3 Planting of $s \bar{a} b i^{`} \bar{\imath}$ sorghum and cowpea (dijra) in Tihāma.

5 Chickpeas (humuș) planted along with sorghum and plucked after three months.

7 Abundance of lemons.

8 Qiyạ $\underline{d}$ harvest of of broad beans (fül) and safflower ('usfur) in eastern Yemen (alMashriq).

9 Qiya $\bar{d}$ harvest of barley in Janadīya and the surrounding districts.

15 In al-Hujarīya parching (jaḥish) begins.

20 Harvest of grains in part of al-Hujarīya. 
29 Planting of wheat in the Ta'izz district where there are perennial streams (ghayl) until mid-Tishrīn al-Thānī (November 28).

November (Tishrīn al-Thānì)

2 Harvest of grains and gharb sorghum begins in al-Hujarīya.

7 Violets (banafsaj) planted.

14 In Ibb "the bull does not enter [the fields] under thawr (a star in Taurus)."

15 Barley harvest, lasting half a month in the mountains.

21 Mists (ghaym) are frequent.

December (Kānūn al-Awwal)

7 Qiyä harvest of wheat after the sorghum.

16 Grain is planted in part of Tihāma.

25 Tree leaves fall. 
6. Nello Lambardi. Divisioni Amministrative del Yemen con Notizie Economiche e Demografiche. Oriente Moderno 27(7/9): 143-162, 1947 $7^{110}$

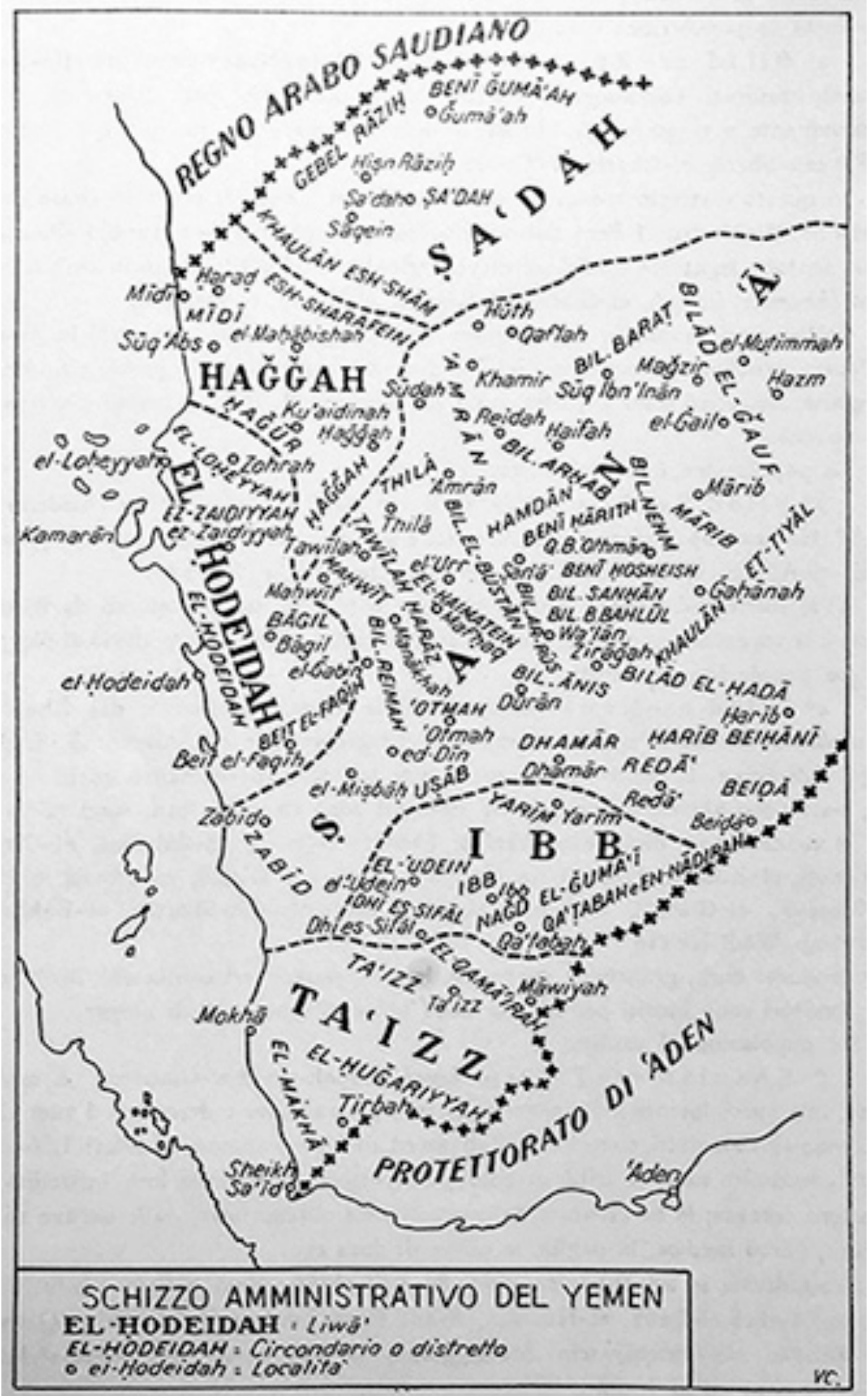

Administrative map of Yemen for 1940-44 (Lambardi 1947: 145)

${ }^{110}$ A later article by Pietravalle (1952) also provides information on Yemeni agriculture, but this appears to mainly be taken from Lambardi's work. 
Drawing on statistics provided by the government of Yemen and personal reconnaissance, the Italian Nello Lambardi published an annotated list of the administrative districts of Yemen for the years 1940-1944. At the time the kingdom was divided into six provinces (alwiya/liwä', sg.). These were Șan'ā’, Ibb, Ta'izz, al-Hudayda, Hajja and Șa'da, the latter also known as al-Shām and al-Qibla. Each province was divided into a major district (qad̄à'/qadawāt, pl.) and then another district known as nāhiya (nawāḥ̄, pl.). This was in turn made up of a variety of smaller units, such as the tribe (qabīla/qabā'il, pl.), 'uzla ('uzal, pl.), qism (aqsām, pl.), mikhläf (makhālīf, pl.), habl (hibāl, pl.), khums (akhmās, pl.); and thumn (athmān, pl.). It is important to note that in this system the largest province was Șan'ā', stretching south to Dhamār, east to Bayḍā' and Ma'rib and north to Hūth and including Zabīd in the Tihâma. The article provides information on agricultural products for each area, as well as three charts documenting the zakāt tax, customs duties and jizya tax on Jews.

The following translation provides the information on agriculture, as delineated by Lambardi for the kingdom.

\section{San'ā’ Province}

Șan'ā' was the seat of government for the Imam. Western observers estimated a population of 30,000 for the city, but the Yemeni publication 'Ilm al-buldān from 1360/1941 indicated 50,000 from the official register (al-muhāsaba al- 'āmma), rising to 80,000 including Bi'r al-'Azab, Qā' al-Yahūd and the nearby localities of 'Așur and Bayt Mi'yād. The province as a whole was said to have a population of 394,906 .

I.1 Bilād al-Bustān (nāhiya): population 32,634, divided into 10 units. The main crops are coffee and $q \bar{a} t$. The Matari coffee variety is considered the best; $q \bar{a} t$ is grown to the south; cereals in the north with sorghum in the colder areas; other crops are wheat and barley, legumes and fruit in Hadda.

I.2 Bilād al-Rūs and Banī Bahlūl (nāhiya): population 9,540, divided into 4 units.

Crops: wheat and barley, sorghum, legumes, vegetables, $q \bar{a} t$, a little fruit and tamarisk groves. Bilād al-Rūs has poor fields of volcanic soil and Banī Bahlūl, with a scarcity of water, is poor.

I.3. Bilād Sanhāan (nāhiya): population 10,484, divided into 5 units.

Crops: cereals, legumes, vegetables, grapes, $q \bar{a} t$, several kinds of fruit trees. Because of the scarcity of natural vegetation, many fields are not cultivated due to neglect and the shortage of rain.

I.4 Bilād al-Ḥadā (nāhiya): population 18,074, divided into 16 units with some Bedouin nomads.

Crops: sorghum, maize, wheat and barley, legumes, mustard, fenugreek, etc. Most of the area is uncultivated due to neglect by the inhabitants and the scarcity of rain.

I.5 Khawlān al-Ṭiyāl (nähiya): population 12,160, divided into 6 tribes. The Imam exempted the tribes here from paying the zakāt tax on vegetables, medical herbs, straw, sorghum stalks, etc.

Crops: Due to the scarcity of rain, the cultivation is limited to cereals and legumes.

I.6 Banī Ḥushaysh (nāhiya): population 9,353, divided into 8 units. 
Crops: fruits, figs, vegetables, watermelons, $q \bar{a} t$, sorghum, wheat and barley. This is a fertile area (especially Wādī al-Sirr, Wādī Rijām, Wādī Sa'wān and al-Rawna).

I.7 Ban̄̄ al-Hāāith (nāhiya): population 16,474, divided into eight units.

Crops: rich area with grapes, fruits, $q \bar{a} t$, vegetables, cereal grains, legumes, sorghum and lush tamarisk ${ }^{111}$ groves.

I.8 Hamdān ibn Zayd (nāhiya): population 38,393, divided into 4 units.

Crops: $q \bar{a} t$, fruits, vegetables, cereal grains in discrete quantities.

I.9 Bilād Arhab (nāhiya): population 16,092, divided into six units.

Crops: cereal grains, legumes and grapes in Mirrān, but there is a scarcity of rain and springs.

I.10. Nihm (nāhiya): population 5,657, divided into 6 units.

Crops: sorghum, other cereal grains, legumes, a little $q \bar{a} t$, grapes and fruits.

I.11 Ma'rib (nāhiya): population 15,490, divided into 4 units. The inhabitants are said to be fierce and bellicose Bedouins.

Crops: There is a scarcity of rain and springs and only a small amount of cultivation limited to cereals. $^{112}$

I.12 Harīb Bayḥānī (nạhiya): population 11,320, under the influence of the English with some Bedouin nomads and rock salt merchants.

Crops: sorghum and cereal grains with abundant livestock.

I.13 Jawf (nähiya): population 10,768, divided into 8 units. The inhabitants are a mixture of sedentary farmers and Bedouin nomads. The tribes are said to be fierce and bellicose.

Crops: sorghum, cereal grains of excellent quality, barley, excellent oil seeds, etc. and an abundance of livestock.

I.15 Barat (nāhiya): population 4,297, divided into 4 units.

Crops: Similar to the Jawf with limited agriculture and scarcity of water.

I.15 'Amrān ( $q a d \bar{a}$ '): population 235,558, divided into 14 districts.

Crops: sorghum, cereal grains (especially the famous wheat $a l$-bawni $)$, legumes, coffee (especially in Wādī 'Usmān), vegetables, qāt, various fruits (e.g., figs and apricots), some grapes, many bananas, mustard, cotton and tobacco (in Wādī Shuwāba).

I.16 Thulā' (nähiya): population 14,373, divided into four parts.

Crops: Similar to those in 'Amrān, but particularly mustard, from which oil is extracted.

I. 17 al-Ṭawila ( $q a d \bar{a}^{\prime}$ ): population 85,500, divided into seven districts.

Crops: This is an agricultural area, especially Wādī al-Ahjur, producing sorghum cereal grains, emmer wheat, barley, maize, lentils and other legumes, coffee and a variety of fruit trees.

I.18 al-Mahwīit ( $q a d \bar{a}^{\prime}$ ): population 93,540, divided into seven units.

\footnotetext{
${ }^{111}$ Tamarisk wood was used for plow beams and its brush was used to construct temporary barrages to divert flood water (Naval Intelligence Division 1946: 590).

${ }^{112}$ In 1927 al-'Azm (1986: 381) observed sorghum, barley, wheat and sesame (juljulān) growing on flood land near Ma'rib, and provides a detailed description of the former dam site in his travel account. He also saw a small garden planted by the soldiers there with chili pepper, radish (qushmi or fijl) and basil (rayhān), noting that all were very tall.
} 
Crops: The area between the mountain slope and valley floor is well equipped with springs and rainwater that allows for varied and productive cultivation. There is a wealth of sorghum and its varieties. Coffee is cultivated around al-Mahwīit and Wādī Yusr, along with $q \bar{a} t$. The crops include a variety of cereal grains, maize, millet, barley, fenugreek, various legumes, vegetables, a type of beet root (barbabietola in Italian) that is particularly sweet, good sesame and a variety of fruits, such as apricots, pomegranates, mangos, papayas, bananas, etc. There is also an abundance of livestock.

I.19 al-Hayma ( $\left.q a d \bar{a}^{\prime}\right)$ : population 28,842, divided into al-Hayma al-dākhilīya with 8 units and al-Hayma al-khārijīya (with 4 units.

Crops: coffee, sorghum, maize, wheat, barley, millet, mustard, fenugreek, qāt , bananas, mangos, vegetables, tamarind. Lumber is taken from the tanūb tree. ${ }^{113}$

I.20 Harāz (qad̄a'): population 120,878, divided into 13 districts.

Crops: The major cultivation is coffee, but there are also other crops and many fruits and natural trees due to the abundance of water.

I.21 Bilād Ānis (qaḍ̄'): population 57,800, divided into six units.

Crops: citrus fruits in Ḥammām 'Alī, in the regular rainfall areas and important Wādīs of Rima', Jarāra, Ānis and Sihām there is an abundance of cereals and legumes, wheat, barley, millet, lentils, fava beans, broad beans [fagioli in Italian), fenugreek, especially yellow sorghum, most of Yemen's cotton, coffee, qāt, as well as excellent honey. There is an abundance of livestock and natural trees.

I.22 Rayma ( $q a d \bar{a}^{\prime}$ ): population 154,080, divided into four districts.

Crops: This zone is very mountainous with numerous small Wādīs and excellent cultivation, especially of sorghum and coffee, as well as other cereals and legumes. In addition to the livestock, the wild animals are leopards, ocelots, ibex and gazelles.

I.23 'Utma (nāhiya): population 49,960, divided into 6 units.

Crops: This area is well supplied with springs and rain, producing cereal grains, coffee, $q \bar{a} t$, honey, etc.

I.24 Dhamār ( $q a d \bar{a}^{\prime}$ ): population 56,721, divided into al-Maghrib al-'Ālī with 2 units and alMaghrib al-Sāfil with 9 units.

Crops: sorghum, cereal grains, legumes, etc.

I.25 Ridā' (qad̄̄'): population 39,590, divided into seven units.

Crops: Despite the desert parts, this has vast areas cultivated in cereals, legumes, maize, sorghum, fruit trees, grapes, etc.

I.26 al-Bayḍā' ( $q a d \bar{a}^{\prime}$ ): population 49,816, divided into three districts.

Crops: the normal crops, such as cereal grains, legumes, certain fruits and a few grapes.

I. 27 'Ușāb (qaḍ̄'): population 56, 915, divided into 11 units.

Crops: cereal grains, legumes, coffee, $q \bar{a} t$, etc.

I.28 Zabīd (qad $\bar{a}$ '): population 131,890, divided into 5 units.

${ }^{113}$ Al-'Azm (1986: 79) lists the crops grown in al-Hayma as sorghum, lentils, barley and wheat with coffee, $q \bar{a} t$, banana and mango grown in Wādīs to the north. The tanūb tree is Cordia abyssinica. 
Crops: Along the coast there is little cultivated land, but inland is well cultivated, including cotton, palms and cereal crops.

\section{Ibb Province}

The population of the province was 422,115 .

II.1 Ibb (qad $\left.\bar{a}^{\prime}\right)$ : population 107,458, divided into six principal units.

Crops: This is the richest agricultural area of the province, which produces sorghum, maize, cereal grains, qāt, coffee, tobacco, fruits and vegetables. Local vegetation is abundant, as are the livestock.

II.2 Yarīm ( $\left.q a d \bar{a}^{\prime}\right)$ : population 87,472, divided into two districts.

Crops: wheat and barley, sorghum, legumes, mustard, vegetables, fruits, as well as numerous beehives and livestock.

II.3. al-Nādira and Qa'țaba ( $q a d \bar{a}^{\prime}$ '): population 62,379, divided into two districts.

Crops: wheat and barley, legumes, $q \bar{a} t$ in abundance and exported, fruits and citrus, as well as honey. This mountainous area has numerous perennial watercourses, especially in Wādī Banā and Wādī Tubbān.

II.4 Najd al-Jumā'‘ (nāhiya): population 17,148, divided into 5 units.

Crops: The same crops and conditions as in al-Nādira and Qa'taba.

II.5 Dhī al-Sifāl (nāhiya): population 27,895, divided into 8 units.

Crops: wheat and barley, sorghum, maize, fenugreek, coffee, $q \bar{a} t$, fruits. There are numerous sheep and cows.

II.6. al-'Udayn ( $q a d \bar{a}^{\prime}$ ): population 119,763, divided into two districts.

Crops: coffee, $q \bar{a} t$, wheat and barley, legumes, vegetables, mangos, bananas, and there is said to be sugar cane (qand).

\section{Ta'izz Province}

The population of the province was 605,964 .

III.1 Ta'izz (qad̄̄'): population 272,445, divided into 4 districts.

Crops: Due to the springs and rainfall, this is a good area for production of cereals, legumes, vegetables, bananas and fruits. So much $q \bar{a} t$ is cultivated that it is exported; both $q \bar{a} t$ and coffee are grown in Misrākh. There is an abundance of livestock.

III.2 al-Qamā'ira ( $q a d \bar{a}^{\prime}$ '): population 73,631, divided into 5 units.

Crops: Agriculture is well maintained and it is rich in livestock, especially the donkey variety of sawraqīya.

III.3 al-Hujarīya (qad̄a'): population 192,392, divided into 12 units.

Crops: Agriculture is similar to that of al-Qamā'ira.

III.4 al-Makhā ( $q a d \bar{a}^{\prime}$ ): population 67,496, divided into 5 areas.

Crops: This is a vast area with date palms along the coast and in the interior there are cereal crops, legumes, $q \bar{a} t$ and coffee.

IV. al-Hudayda Province

The population is 654,039 .

IV.1 al-Hudayda (qad $\left.\bar{a}^{\prime}\right)$ : population 238,867 , divided into 5 units. 
Crops: This dry and hot area is rather poor for agriculture, but the fertile and higher area of Bura' produces sesame, $q \bar{a} t$ and coffee.

IV.2 Bayt al-Faqīh ( $q a d \bar{a}^{\prime}$ ): population 138,617, consisting of the Zarānīq tribe, known for their fierceness and trouble making and working on land and the sea as well as in piracy.

Crops: cereals, sorghum, sesame, some vegetables, dates and cotton.

IV.3 Bājil (qaḍa'): population 106,379, divided into 5 units.

Crops: The area of Wādī Bājil and Wādī Sihām is cultivated with sorghum, but in an unhealthy climate. The other crops are similar to those in nearby districts.

IV.4 al-Zaydīya ( $\left.q a d \bar{a} \bar{a}^{\prime}\right)$ : population 96,720 , divided into 5 units.

Crops: sorghum, the very poor variety of gharb sorghum, millet, maize, sesame, dates, vegetables, grains, barley, $q \bar{a} t$, coffee and fruits.

IV.5 al-Luhayya (qadā'): population 73,456.

Crops: The district along Wādī Mawr and Wādī Sultạn has abundant perennial water, producing sorghum, gharb sorghum, millet, maize, sesame, cotton, dates, etc.

\section{Hajja Province}

The population is 553,107 .

V.1 Hajja ( $\left.q a d \bar{a}^{\prime}\right)$ : population 210,404, divided into 10 units.

Crops: sorghum, gharb sorghum, millet, wheat, emmer wheat, legumes and all the plants appropriate to the highlands, as well as some fruits and extensive cultivation of coffee and $q \bar{a} t$.

V.2 al-Sharafayn ( $q a d \bar{a}^{\prime}$ ): population 89,912, divided into 9 units.

Crops: The agriculture is similar to that of Hajja, in addition to some grapes. There is an abundance of livestock.

V.3 Hajūr ( $q a d \bar{a}^{\prime}$ ): population 27,038, divided into 3 units.

Crops: This is similar to Hajja and al-Sharafayn, with an abundance of springs and rain.

V.4 Mīdī ( $q a d \bar{a}^{\prime}$ ): population 225,753, divided into three main areas: Mīdī on the coast, Haraḍ in the interior and 'Abs to the south.

Crops: Because of the meager rain and the hot climate, especially along the coast, the cultivation is limited to sorghum, millet and gharb.

\section{Sa'da Province}

The population is 439,356 .

VI.1 Ṣa ‘da and Sinnāra ( $q a d \bar{a}^{\prime}$ ): population 138,427, divided into 6 units.

Crops: cereals, legumes, fruits, grapes. The area is rich in livestock.

VI.2 Sāqayn (nāhiya): population 119,695.

Crops: This is a mountainous zone with abundant honey.

VI.3 Jabal Rāzih (nāhiya): population 89,913, divided into 5 units.

Crops: abundance of $q \bar{a} t$ and coffee.

VI.4 Jumā'a (nāhiya): population 91,321. 


\section{FAO. Report of the FAO Mission to Yemen. Rome: FAO, 1960}

In the last three months of 1955 an FAO mission visited the Mutawakkilite Kingdom of Yemen "to make a general survey of the food and agriculture resources of the country and of the problems involved in the development of those resources" and to propose recommendations for agricultural development. ${ }^{114}$ The report, consisting of 99 pages, was divided into the following sections: I: The People and the Environment; II: The Agriculture of Yemen; III: Marketing and Foreign Trade; IV: Nutrition; V: Development and Improvement of Agricultural Production, and Food Distribution and Consumption; VI: Summary and Main Recommendations. The team was led by Dr. A. W. R. Joachin, a general agriculturalist, and included an agricultural economist and marketing expert, irrigation and drainage engineer, veterinarian and animal production expert, forestry expert, horticulturalist, and expert in rice production. Joining the team was an interpreter and the FAO locust control expert. A coffee expert and fisheries specialist had visited Yemen for FAO earlier.

The information in the FAO report, while valuable for its time, suffers from several factors. First, the team was only permitted to visit the Tihāma and the central highlands between Șan' $\bar{a}$ ' and Ta'izz with a brief trip to Ma'rib. They also did not observe the entire annual cycle of cultivation. Some of their conclusions reflect this lack of exposure to the kingdom as a whole. For example, it is reported that animal manure is rarely applied to crops, because there is so little of it. This really depends on the region; such manure is also more likely to be applied where there are wells or springs. The experts reflect the bias of the time in promoting "modern" methods and assuming that many past practices were too primitive. While the team was clearly impressed by the capabilities of Yemeni farmers, they found out very little about traditional methods other than what they saw in their brief observations. The claim that there is a complete absence of pest and disease control is not accurate.

In 1955 the FAO mission concluded that only about $2 \%$ of the area of the country was cultivated. They reported little use of wells in the Tihāma, which relied heavily on the floods that descended in the Wādīs from the highlands. Coffee was said to be the characteristic crop of the foothills and middle heights, along with sorghum, wheat, pulses, lucerne, citrus, papayas, pomegranates, bananas, tomatoes, onions, okra and horse-radish. The report focuses on irrigation in the highlands, reporting wheat, barley, sorghum, grapes, figs, pears, walnuts, plums, coffee, lucerne, potatoes, okra, onions and tomatoes. Regarding the terraces, the report states that they are "exceptionally well built and, in general, very well maintained."

Summarising the state of agriculture in Yemen, the report notes: ${ }^{115}$

"On the while, the country is largely self-sufficient as regards its food supply. Large potential resources for agricultural production are untapped, though there is striking evidence of the existence, in years gone by, of an advanced agricultural system which even the ravages of centuries have not been able to eradicate. This is exemplified in the skill displayed by most Yemeni farmers in the feeding and rearing

\footnotetext{
${ }^{114}$ FAO (1960: 1). All the information in this section is taken from the FAO report, which was a mission report and unpublished.

${ }^{115}$ FAO (1960: 13).
} 
of livestock, and, even more so, by the contour terraces for soil and water conservation on some of the mountain slopes and by the earth banks erected to retain flood water and silt in the plains. Yemen is probably one of the best terraced countries in the world; thanks to these terraces, agriculture has been developed and maintained in the generally friable volcanic soils. their stone retaining walls - in some places they are over 3.5 meters high - are indeed a tribute to the enterprise and energy of a people with a fine tradition of, and aptitude for, agriculture. Even today they display this aptitude to a remarkable degree."

In terms of land tenure, this differed according to the ecological zone. Larger holdings with mainly absentee ownership predominated in the Tihāma and in parts of the middle heights. In the mountains, however, the land holdings were small and usually owned by the farmer, except near the larger cities and towns. The team was told that more than $90 \%$ of farmers owned the land they cultivated. Tenancy shares depended on the type of crop and the availability of water for irrigation. The shares of the tenant, they write, "after the deduction of taxes, are, at most, 25-30 percent of the produce of the trees and from 40 to 70 percent of the grains." In the San 'â' area, for example, the share on rainfed land was 45 percent for grains and 30 percent for trees; on ghayl or flood irrigation for grains the share was 45 percent if the water source was owned by the landlord and 60 percent if the source was communal, but 30 percent for tree crops. For well irrigation the share was said to be 70 percent.

At the time the authors thought that water resources were "generally adequate" except for the dry eastern area. They note that most of the channels used for irrigation of flood water in the Tihāma are "very defective" and lose much water through seepage and negligence by the irrigators. However, the diversion method is said to be "very efficient" due to the high-moisture retaining capacity of the soils. As a result they recommend that the existing system not be discarded but improved by adding better control works. Wells were common in the highlands where the groundwater was accessible. The average depth in Șan'ā' was 20 meters, 10 meters in Ma'bar and 5-10 meters at Yarīm. Their observations led the team to conclude that generally "cultivators make good use of the water available." Floods in the wādīs are described as "relatively short and torrential," with flood peaks at times exceeding 1,000 cubic meters per second. Recognising that sufficient hydrologic data was not yet available, the report suggests that the total annual rainfall would be roughly 10 billion cubic meters (based on annual rainfall of 500 millimeters for 20,000 square kilometers catchment on the western slope), resulting in about 2 billion cubic meters per year in annual runoff.

As might be expected, the FAO team regarded the tools of the farmers as "extremely rudimentary implements." Despite this, it is noted that furrows and ridges made with their tools "are almost perfectly executed." They discussed the local agricultural methods as follows:

"To prepare the soil, the land is plowed with primitive wooden plows... in which an iron-capped spike is driven simply forward, but there is no curved plow-share to turn the soil. Sometimes the soil is laboriously turned by a team of three men who follow the plow with a heavy shovel; and one wields the handle, while the other two men hold cords attached to the blade. Sometimes women follow the plowman and break 
the clods with wooden mattocks. No harrow is used, but wooden levellers with an iron border are employed to complete the work after the plow. They are dragged by oxen or other beasts, and the driver stands on the boards.

In the vineyards the soil is trenched with long-bladed mattocks, in which the curved blade or iron spike is nearly at a right-angle to the handle. This kind of hand hoe, called 'fas' or 'mafras'... is practically the only implement widely used for tilling, digging or hoeing the soil by hand. Shears, saws and pruning tools are practically unknown by the farmers for use in orchards.

There are no harvesters or threshers. Wheat and barley are reaped by men, boys and girls, who grasp handfuls of the stems and saw through them with a sickle, or sometimes those crops are torn up by the roots. Threshing is done with flails or by cattle treading the sheaves of grain spread on the ground. Sometimes a heavy rectangular stone is drawn by a pair of bullocks over the grain to thresh it."

There was a general lack of tractors, apart from those the team observed at the Jarouba Estate Farm in the Tihāma.

The report provides details on the crops grown in Yemen. These can be summarised as follows:

Sorghum: Sorghum sp. was the dominant crop, estimated to be grown on 200,000 ha between sea level and 3,000 meters. This crop was cultivated on both irrigated and rainfed land for its food and fodder values. Some ratooning was possible if the water was sufficient and sometimes it was interplanted with pulses. The average yield for Yemen was estimated at 1.5 metric tons per ha. In good years some would be exported to nearby countries.

Bulrush millet: Pennisetum sp. was said to be the second most common cereal in Yemen, mostly on more marginal land in the Tihāma and lowland areas. One advantage was that little attention needed to be paid to it once planted. It was also important in dry years.

Wheat and barley: Spring and winter varieties are cultivated mainly in the highland plateaux of Șan'ā', Ma‘bar, Dhamār and Yarīm. Yields were said to be poor with rust and other diseases common.

Maize: This was said to be cultivated mainly in the lowlands and middle altitudes, especially where it could be irrigated. Yields were reported to be reasonably good.

Rice: Rice was considered an unimportant crop in Yemen, perhaps no more than 100 ha being cultivated in Yemen. ${ }^{116}$ In 1953 some 387 tons of rice were imported into Yemen. The team observed that in the area of al-Hūth, north of San' $\bar{a}$ ', rice was grown on a maximum of four ha at 1,000 meters, but often less due to the lack of sufficient water. In another area on land belonging to a son of the Imam American rice seed had been introduced some three years before, but it was poorly planted.

\footnotetext{
${ }^{116}$ Forbes (1923: 275) saw rice growing in the "Asīr region. Qādī Muhammad al-Akwa' (1979: 106), reflecting on the early part of Yahyā's rule noted that in Yarīm there were those so ignorant of rice they thought it was worms.
} 
Pulses: These included broad bean (Vicia faba), lablab (Dolichos lablab), fenugreek (Trigonella foenum-graecum), lentils (Lens seculentis), green gram (Phaseolus aureus), cowpeas (Vigna sinensis), moth bean (Phaseolus acontifolius), and groundnuts.

Sesame: Sesamun indicum is indicted as the second major crop in the Tihāma, where it is cultivated mainly under irrigation, but also on rainfed land. It was frequently grown in association with sorghum in flood irrigated areas. The team noted a bad infestation in some areas of the termite Cryptotermes sp.

Coffee: Coffee was said to be the main expert item of the kingdom, annually about 4,000-5,000 tons. ${ }^{117}$ In 1954 almost 2,000 metric tons of coffee were shipped to the United States of America, 666 metric tons to Aden and 1,000 metric tons to Saudi Arabia and the Gulf. Three special features were noted of coffee in Yemen: it was generally grown under irrigation, ${ }^{118}$ largely free from pests and diseases, and the bean was rarely consumed in Yemen. The main varieties listed in the report are: Yamān̄̄ (grown in al-'Udayn and Wașāb), sharqī (grown in Ānis and 'Utma), Raymī (grown in Rayma), Bur'ī (grown in Jabal Bura'), Șan'ānī (grown in Ḥayma and Ḥarāz), Maṭarī (grown in Banī Maṭar) and Shāmī (grown in Hajja, Milḥān, Kuhlān, Hụāāsh, alMahābisha). The coffee husk (qishr) was used to make a drink while the beans were exported. About 6,000 ha, from 1,200 to 2,100 meters elevation, were said to be cultivated with coffee. Shade was almost universal, especially from species of Cordia and Ficus. No annual pruning was observed, but some manure and ashes were applied. Damage can be made by locusts. It was noted that coffee production had decreased, attributed by some to an increase in cultivation of $q \bar{a} t$.

Cotton: The team notes that the commercial scale of cotton for cultivation in Wādīs Zabīd, Rima“ and Mawr is a recent development, although cotton has traditionally been grown. The variety cultivated was the "stapled Sakal type Sudan 1730" with an increase of 80 ha in 1951 to 1200 ha in 1954. The kingdom subsidised a private organisation to operate the scheme and determine pricing for the ginnery in al-Hudayda.

Tobacco: This was cultivated with irrigation in the lowlands and the highland plateau during summer. The variety cultivated was tunbāk for use in the waterpipe (madā'a). Profits were high due to a hefty duty on imported tobacco of the same type.

Horticulture: Horticulture was said to be of limited importance due to the almost total lack of marketing facilities for perishable produce.

Fruit Culture: The main fruits mentioned for the Tihāma (from sea level to about 200 meters elevation) are the date palm, banana and papaya. In the foothills and middle heights (200 to 1,500 meters elevation) there was a wide variety of species, including citrus, pomegranates, papaya and banana. Temperate fruit species grown in the highlands included grapes and deciduous varieties such as figs, pears, peaches, apricots, apples, quinces, walnuts and stone fruits (except cherries). It was argued that all orchards are irrigated and generally have several species planted together.

\footnotetext{
${ }^{117}$ At this time Yemen's export of coffee was only 0.2 percent of the world trade.

118 The team seems unaware that the mists rising up into the Western escarpment allowed coffee production on rainfed land.
} 
Planting trees to close to each other and lack of pruning limit yields. No manure was reported to be used, nor pest control.

Date Palm: Phoenix dactylifera is grown primarily in the coastal part of the southern Tihāma and higher parts of the wādī valleys, often in association with the dūm palm (Hyphaene thebaica). The team was unable to give a figure for the total area cultivated with date palms, but noted that the areas visited contained between 200,000 and 250,000 trees. Specific areas mentioned for date palms included about 500 ha south of al-Khawkha, where it is said that some families have four or five trees, and some have 6,000, all irrigated from wells. Wild bushes were noted to be growing between the palms with no major diseases or pests reported. Other areas include Jarūba at 20 kilometers southwest of Bayt al-Faqīh, Murzay'a some 20 kilometers northeast of alḤudayda, 'Unkufa at 5 kilometers south of al-Zuhra, and near 'Ubāl, Zabīd, Hays and Mocha. Plantations were noted at Wādī Barah 60 kilometers east of Mocha, and one of 20,000 trees reported midway between Ta'izz and Hays. The main varieties mentioned include munāsif, which is half soft and half hard, lubān, a small blackish-red date, "Tubayki" a yellow and dry fruit, 'Uraykī (hard and dry red fruit), al-khudāāi (green fruit $10 \mathrm{~cm}$ in length), "Khondari, Mechtoum and Magini."

Citrus: These were generally recent, with some 20,000 seedlings introduced during the previous few years. They were planted in Ḥammām 'Alī ten years before, near Ta'izz some six years before, Ibb and in the Tihāma at Jarūba and Dār al-Nāja. The best results were reported above 1,500 meters. The specific varieties included sweet oranges, tangerines, sour and sweet lemons, limes and citrons. No pruning or pest control was observed, but diseases and pests were noted.

Banana and pawpaw (i.e., papaya): These local varieties are said to be very common in the Tihāma, especially at Jarūba and al-Khawkha, the foothills east of Zabīd, the wādī valleys, and in the regions of Ta'izz, Ibb and Ḥammām 'Alī.

Mango, Guava, Custard Apples: These were not widespread and only a few isolated trees were observed in Ta'izz and parts of the Tihāma.

Pomegranates: Both sweet and sour varieties are widespread throughout Yemen, especially in Ta'izz, Șan'ā' ("Soyani and Bovari” varieties), Ibb and Yarīm (two sweet varieties being "Malaesi and Hosrumi"). There is the worm Virachola livia as well as splitting of the fruit.

Stone fruits: For the central plateau area between 1,400 and 2,300 meters of Șan'ầ', Ibb, Yarìm, Ma'bar, Dhamār and Ta'izz the common trees are apricots, peaches, plums and almonds. Yemeni apricots were reported as "fruit of very good quality, juicy, very sweet and perfumed." Several pests and fungus diseases were noted.

Pears and Quinces: A few isolated pear trees of 10 to 12 meters high and 100 to 200 years old were observed in the central plateau areas of Șan'ā', Ibb and Yarīm.

Apples: Only a small number of trees in the central plateau were observed, but some American varieties had recently been imported. Pests included scale insects, aphids and borers.

Figs: Figs were widespread in the mountain areas and only eaten fresh.

Grapes: About 40 varieties of grapes are grown, especially in the Șan'â' area, but also in Dhamār, Ibb, Ta'izz and Șa'da. The most important are rāziqì (small, white, seedless), 'ạșimì (large 
greenish-yellow with pink side, very pulpy and sweet), 'îrq $\bar{\imath}$ (white seeded and the latest to mature), as well as black varieties. Grape production is described as follows:

"The vine plants are generally trained in trellises supported by stone pillars about 1 to 1.5 meters high. Distance between plants is generally $2.5 \times 2.5$ meters. Propagation is done by layering, and grafting was soon. Pruning is general, but too much dead wood is kept. Irrigation is practised during the growing season. Powder mildew (Uncinila necator) was the only disease noted, and generally growers control this disease by sprinkling a special earth. They claim, however, that sulphur flour is more effective. The grapes are ripe from June to October but the atmosphere is so dry in the Șan'à' area that grapes are preserved in good condition on the plants until November and sold in the markets of Ta'iz, San'a and Hodeida even in December and January.

The grapes are packed in wooden boxes containing about 18 kilos each. The sale price in San'a was about 2 rials (1.60) for a box, while in Ta'iz at the same time the price was very much higher because of the cost of transportation (10 rials or $\$ 8.00$ per box).

There is a rather important dried-grape industry in the San'a district (Raudha and Dahr). Raisins and currents of this region are very widely sold in the markets of Ta'iz, San'a and Hodeida. During the last few years the exportation of grapes has reached the level of 300 metric tons per year."

Walnuts: Healthy plantations were observed in Hadda with trees reaching 15 to 20 meters in height. Smaller plantations were noted for 'Aṣur, Wādi Zahr, Rawḍa and Yarīm.

Olives: These were reported to be "practically unknown" in Yemen, apart from a plantation of the Imam in 'Ușayfira near Ta'izz which had not yielded fruit in six years and one in Șan'ā' which had not borne fruit in 15 years.

Other species: Of secondary value were prickly pear (Opuntia ficus-indica), wild jujube (Zizyphus spina christi) and carob (Caratonia siliqua).

Vegetables: Few vegetables are grown in Yemen and they are not much used in meals. Vegetable gardens are primarily in Șan'â'and Ta'izz and their surroundings. In the Tihâma they were observed at Rafih (10 kilometers south of al-Zuhra), 'Unkufa (5 kilometers south of al-Zuhra), Bayt al-Faqīh, 'Abbāsī 10 kilometers west of Zabīd, al-Khawkha and al-Ḍạī.

Potatoes: Yemen appeared to be self-sufficient in production of potatoes. These were produced in areas around Șan' $\bar{a}$ ' and Ibb from local seed, although some new varieties had recently been introduced from Europe.

Other vegetables: The most important other vegetables are okra (Hibiscus esculentus), carrots, onions, garlic, tomatoes, watermelons and horse-radish. On a smaller scale there are leeks, red peppers and chillies, sweet potatoes, eggplant, sweet onions, squash, pumpkin, marrow, cucumber, spinach, cabbage, cauliflower, lettuce, celery, artichokes and green rocket (Eruca sativa).

Pulses: These include various beans, broad beans, lentils, peas, chickpeas, pigeon peas (Cajanus cajan) and small amounts of garden purselane (Portulaca oleracera) and Jews' mallow (Chor- 
chorus olitorius) were cultivated near Șan'ā’ and parts of the Tihāma such as Bayt al-Faqīh and al-Khawkha. These were also exported annually from al-Hūdayda.

Aromatic and seasoning plants: These include dill (Anothum graveolens), parsley, thyme, mint and peppermint. Black cummin (Nigella sativa) seeds were sprinkled on bread. Sweet basil (Ocimum basilicum) is both a kitchen herb and the sprigs are stuck in men's turbans at weddings, etc. or laid among clothes in a chest.

Alfalfa: Medicago sativa is the only fodder crop grown in Yemen. The team reports that it is not grown under irrigation around Șan'ā', Ma'bar, Dhamār and Yarīm and is sometimes grown between grapevines and in orchards. ${ }^{119}$ Four cuts per year are reported under dry farming conditions.

The authors of the FAO report note several challenges to development of agriculture in Yemen. The infrastructure was barely developed with poor road transport, there was a lack of organised marketing and price inducements, control and utilisation of water was not properly controlled, modern methods of agriculture were not known and there was no institution to assist farmers. ${ }^{120}$ In addition the team considered the high taxation of produce an impediment to agricultural progress.

${ }^{119}$ Alfalfa or lucerne is also grown under irrigation in the highlands. In the 'Asīr region it is only grown under irrigation (Abdulfattah 1981: 51). It is important to note that sorghum and maize stalks also serve as fodder.

${ }^{120}$ A similar rationale was given by Tarsīsì (1962: 159) for the problems facing agricultural development. 


\section{Huusayn ibn 'Alī al-Waysī, al-Yaman al-Kubrāa. Cairo: Mațba'at al-Nahụa al- 'Arabiyya, 1962}

This important geographical survey of Yemen was made shortly before the 1962 revolution that toppled the Mutawakkilite Kingdom and thus provides an overview of the regional distribution of Yemen's agriculture at that time. Al-Waysī's book consists of 298 pages, with numerous black-and-white photographs, maps and charts. A preface was provided by the Egyptian archaeologist Ahmad al-Fakhrī, who had written about ancient Ma'rib. In his introduction, al-Waysī states that he had been collecting information for this book since 1351/1932. He served as a soldier in various parts of Yemen and made a tour of most of Yemen later by car.

His book begins with a geographic survey (pp. 1-9), including a hand-drawn map of Yemen. He concludes that the area of the Mutawakillite Kingdom was 1,600,000 sq. km. This is followed by a geographical description of southern Yemen (pp. 10-17), at the time under British control, before his lengthy geographic account of the kingdom (pp. 18-125). Information is provided on climate (p. 126), seasons, including a chart of the 28 agricultural marker stars (pp. 126-129), geology (pp. 130-142), and hot springs (pp. 142-147). A section on Yemen's tribal genealogy (pp. 150-162) includes a large genealogical chart. There is also a glossary of Yemeni place names (pp. 163-198) and a discussion of Yemen's pre-Islamic and Islamic history (pp. 199-282), including a list of rulers throughout Yemen's history.

\section{Translation:}

\section{Ta'izz Province (liwā')}

[36] The crops belonging to the fertile agricultural area of Ta'izz are due to the abundance of water in its wādīs. Among the most important crops are coffee, sorghum and its varieties, wheat, and barley. Most of the date palms are in Wādī Rasyān in Maqbana and Wādī al-Zirā' $\overline{1}$, like what is found in Wādī al-Akhmūr, al-Mashāwala, al-Mafālīs, al-Zarrayqa, al-Wāzi'iyya mn alḤjariyya, and Wādī Marza' and al-Zahāwā in al-Mukhā...

Coffee is one of the economic crops of the province of Ta'izz. It is found in large regions suitable for spreading its cultivation in large quantities, such as in the wādīs of al-Masnah, alḤayma, and al-Ḍabāb, the wādīs of Ta'izz and the Wādīs of al-Ḥujarīya, Khadīr, Warazān and Māwiya. Similarly there are regions suitable for cotton, like the region of 'Ușayfira, alMashāwala, al-Akhmūr, al-Mafālīs, Mawza', al-Mukhā, al-Ḥakm, al-Ahmūl, and the wādīs of Maqbana, Rasyān and al-Zirā‘̄î. There are wādīs that could double cereal grain crops if they used groundwater lifted by pumps, such as the wādīs of al-Mashāwala, Ban̄i Khawlān, al-Kalābiya, alDabāb, Khadīr, and the areas surrounding Ta'izz where there is abundant water to exploit, such as al-Da'aysa and al-Ra'ayna of Shar'ab and al-Sūdān of Māwiya, Wādī al-Qamā'ira and alSharmān and the Wādīs of al-Hashma, al-Nashma, al-Hayma and al-Janad of Ta'izz. Fruits include banana, orange, pomegranate, fig varieties, peach, apricot and watermelon (habhab). Although these are in small quantities, it is possible to double production to provide food for the population. 


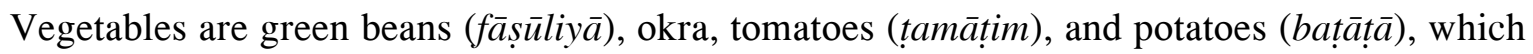
are produced so much that they are exported to Aden. There is also a little production of onions, but this can be developed in many regions for export.

Ibb Province (population 600,000)

[45] The population of Ibb province is supported by agriculture. The most important and abundant crops of the province are cereal grains, coffee, potatoes and $q \bar{a} t$. The fruits include bananas alongside the variety of fruits previously mentioned for the province of Ta'izz, as is true for what was mentioned about vegetables. Pseudo-saffron (wars), from which a dye material is extracted, is cultivated. There is a small amount of sugar cane in the Wādīs of al-'Udayn. In general the area is more fertile than Ta'izz.

al-Baydā' Province (population 150,000)

[47] Harīb is 1,000 m above sea level; pumps for lifting water have been introduced and the residents of Wādī al-Khașīb benefit from this... [48] The most famous town is al-Bayḍā'... and it rises $1,800 \mathrm{~m}$ above seas level ... Fruits of grapes and figs are found in it and there is plentiful underground water. The second most important town is $\mathrm{Rada}^{\circ}$, and it enjoys a temperate climate and they use pumps for raising water resulting in a verdant garden area. Fruits of grapes, figs and pomegranates are plentiful. Its elevation is similar to San' $\bar{a}$ ' at $2,100 \mathrm{~m}$ above sea level. [50] In Radā', al-Jūba and Harīb most of the residents work in making woolen clothing. The people are supported by agriculture and livestock raising of camels and sheep, from which they take the wool... In al-Bayḍā' there is active commerce because of its strategic location in connecting to Aden. It is a region suitable for cultivation of cotton, wheat, barley and fruits.

San'ā' Province

[57] Qaḍā' Ānis: present in Wādī al-Ḥamām are many fruits, such as oranges, lemons, bananas and other crops. Bilād Ānis is famous for its coffee, livestock raising and agriculture... Qaḍā' Rayma is the most famous mountain area in Yemen for its fertility... [58] The population of the qad $\bar{a}$ ' of Rayma reaches 100,000 and it is famous for the cultivation of coffee, cereal grains and the fruits of mangos and bananas. Agriculture is carried out alongside livestock raising... [60] The residents of Harāz equal 50,000 and the energy of the residents is devoted to the cultivation of coffee, cereal grains and livestock raising, except for Manākha, where most of the residents engage in commerce and the external export of coffee through al-Hudayda.

[61] The most famous town of the qad̄a ' of al-Mahwīt is al-Mạwīt, whose residents work in commerce, especially trade of tobacco and coffee which are present in Sumi' and Wādī al-Hirra in Sāri‘. Most of the residents engage in the cultivation of coffee, cereal grains and livestock raising... [65] The population of Kawkabān province is about 50,000 and most are working in agriculture and livestock raising... [66] The population of Thulā' province reaches about 20,000. Its most important cultivation is for the varieties of cereal grains and its fruits are apricots, plums and quince.

[69] The district (nāhiya) of al-Hadā is an agricultural region, having Wādīs which are suitable for the cultivation of coffee, fruits, grapes and figs, as well as planting of cereal grains in their different varieties. Most of the residents work in agriculture and livestock raising... [For 
the district of Khawlān al-'Āliyya or Khawlān al-Ṭiyāl] [70] Wādī Harīb is divided between the tribes of Khawlān and Nihm, and excellent quality coffee is grown there. The most famous of the mountains in Khawlān are Jabal al-Lawz, the mountains of al-Ṭiyāl, Jabal al-Khaḍrā' and Jabal 'Aḍiya, which form a chain from east to west, and where there is much cultivation of almonds (lawz)... The fruits grown in Khawlān include good quality grapes in Maswar, al-Kibs, Qarwā and al-A'rūsh just as almonds are plentiful in Jabal al-Lawz, and al-Ṭiyāl of the Banī Jabr. The residents of the region are supported by agriculture and livestock raising...

[71] [For the district of Banī Hushaysh and Nihm] there is a large wādī with an abundance of grapes... In this region different varieties of cereal grains are cultivated. The fruits include grapes, pomegranates and figs which are plentiful in al-Sirr, Rijām, al-Rawna, Sa 'wān and Hirrat Ban̄̄ Jurmūz, just as there is cultivation of cucumbers, cereal grains and melons (bițtīkh and shammām)... [73] [For the district of Arḥab] among its wādīs is Sha'b and in Bayt Marrān where there are grapes and figs and its cultivation includes sorghum, wheat and barley... [74] [For the district of Ban̄i al-Hārith] its important agriculture is from fruits like grapes, walnuts and almonds, various kinds of vegetables and there is much cultivation of lucerne (birsìm). For their agriculture they use water pumps (al-ālāt al-artuwāziyya). Bani al-Hārith has not ceased to be an agricultural area, all of which is suitable for cultivation due to the abundance of its underground water.

[75] [For the district of Hamdān] its most important wādīs are Wādī Ẓahr, Wādī al-Ḍil ‘ and Wādī Lu'lū'a. These wādīs just mentioned are in the autumnal region (makhārif) of San ‘ā'. The term kharif in Yemen stands for the season of autumn, when fruits are plentiful. This is a rain season which dresses the land as though with a silver braid, beginning at 29 Hazīrān until 26 Aylül. This coincides with the season of summer (sayf) in the same northern region. Cultivated in it are fruits, grapes, pomegranates, figs, plums [86], quince, peaches, lemons, oranges, alongside the cultivation of various varieties of cereal grains... [78] [For the district of Sanhāan] Wādī Hizyaz is rich in groundwater, so that some of the wells reach it in 3 meters. The most famous cultivation is of various varieties of cereal grains, fruits like figs, grapes, pomegranates and apricots, as well as livestock raising.

[79] [For the district of Bilād al-Rūs] the population of the region is about 30,000, most of whom work in agriculture and livestock raising... The center of al-Hayma al-Dākhiliyya is al'Irr and the center of al-Ḥayma al-Khārijiyya us Mafhaq and al-Khamīs, both being coffee regions... [80] The energy of the residents is directed at the cultivation of cereal grains, coffee and livestock raising. [81] [For the district of 'Amrān] Wādī Akhraf and 'Uqmān are famous in the area of Hāshid for excellent coffee... [83] Most of the district of 'Amrān cultivates wheat, barley, sorghum and other cereal grains. The fruits are grapes and figs in al-'Ayad and Banī Jubar in the sub-district (nāhiya) of Rayda and Dhībīn. Much coffee is cultivated in the subdistrict of al-Sūda. [85] [For the district of al-Hūth], there is underground water at a depth of 5 or 6 meters, as in the areas of Khabb and al-Jawf. There are areas where water flows on the surface of the ground... [86] The regions of al-Jawf and Sufyān are suitable for cultivation of various kinds, especially date palms, grapes, cotton and tobacco, in addition to wheat, sorghum and barley. 


\section{al-Hudayda Province}

[88] [For the district of Hays] there is sweet water along the coast with many date palms and doum trees, from which mats are made... The elevation above sea level of Jabal Rās is $2,000 \mathrm{~m}$ and in it coffee and a variety of different cereal crops are planted. The region of Zabīd is one of the coastal regions rich in agriculture. The length of Wādī Zabīd for agriculture is $40 \mathrm{~km}$, as is its width... [89] The wādīs of Zabīd are suitable for cultivation of cotton, tobacco, cereal grains and sesame. There is always water in Wādī Zabīd and Wādī Nakhla and of those things anticipated is a stone dam at the top of Wādī Zabīd in the gap of Kubba Ma'ād, which is a small mountain chain. In the district of Zabīd there are areas with many date palms in Nakhla, Zabìd, alKhawkha, al-Tuhaytā and other areas. There is also a place west of Zabīd on the coast called alFāzza, with sweet water springing up. This is always the case because the constant flow of Wādi Zabīd water disappears underground and reappears here. Much white jasmine (fill) is cultivated in Wādī Zabīd. Jasmine is used in the folds of a groom's clothing and in containers within sitting areas to spread the perfume aroma from it around.

[90] In the district of Bayt al-Faqīh date palms are grown, with an abundance in alDurayhamī, Wādī al-Najāh and Wādī Rimāl, with much cultivation of tobacco in Wādī alLāwiya. Cotton is cultivated in Wādī Rima' and al-Husayniyya. Most of the region grows sorghum, millet and sesame... [92] [For the district of al-Hudayda] there is a sub-district connected to it at Jabal Bura', which is east of al-Hudayda more than $60 \mathrm{~km}$ and its elevation above sea level is $2,400 \mathrm{~m}$. This is an area blessed with the cultivation of coffee, where the coffee tree continually produces... [95] [For the district of Bājil] most of the agriculture in the region is for the cereal crops of sorghum and millet, as well as sesame, and there is also present in it tobacco and cotton... [98] The region of al-Zaydiyya is in general an agricultural region. In Wādī Surdud cotton and tobacco are cultivated, as are also sesame, sorghum and millet. The most famous tree in al-Zaydiyya is $d a w m,{ }^{121}$ which resembles the date palm and from which mats and baskets are made to preserve the food. These are called zurüf in the Tihāma, and also made from them are the baskets (zanābi l) and head coverings which are called zulal (zulla, sg.) in the Tihāma... [99] [For the district of al-Luhayya apart from the southern sabkha area] there is one of the most fertile areas with plentiful water that flows through Wādī Mawr, the largest of the coastal Wādīs. This emerges from the eastern foothills of al-Luhayya, traveling though agricultural land for $70 \mathrm{~km}$ with an area width of $40 \mathrm{~m}$. There is always water in Wādī Mawr, but there is not even a tenth of it in al-Zuhra, where the remaining water disappears under the sand. The underground water is at a depth of $3 \mathrm{~m}$ in most of the region... The residents of the region work in cultivation of a new variety of cotton to a great extent, as well as tobacco. The date palms and cultivation of sesame, sorghum and millet do well here.

Hajja Province (population 400,000)

[108] The mountain region is rich in the cultivation of coffee, fruits and cereal of various varieties, as well as livestock production. Rice is cultivated in some of the Wādīs lush with water, such as Aslam and Hajūr, with tobacco and date palms planted in the lower Wādīs. This is

\footnotetext{
${ }^{121}$ This is Hyphaene thebaica.
} 
the case for the mountainous area in the province of Hajja. In all of Ahnūm, Sharaf and Washha there are fruits of grapes, figs and pomegranates... [110] A branch of Wādī Harad irrigates the lands of al-Muwassam, which is located on the border between Mīdī and Jīzān, a region suitable for cultivation of cotton, tobacco, date palms and the cereal grains of sorghum, millet and sesame.

Sa'da Province (population 20,000)

[116] The residents work in agriculture and livestock raising. Coffee is found in Khawlān ibn 'Āmr, Rāziḥ, and the mountains of Western Jumā'a. Grapes and fruits such as figs, pomegranates, peaches and apricots are found in the region of Hamdān ibn Zayd, Saḥār and Jumā'a.

'Asīr and Najrān Province

The most important crops of Najrān are dates and various varieties of cereal grains. The excellent quality dates are sent to Șa'da and San'à'. 


\section{Overview of Agriculture in Mutawakkilite Yemen:}

On the eve of the 1962 revolution that signaled the end of the Zaydī imamate in Yemen, a wide variety of crops was cultivated (Annex A). Up to this time, apart from occasional poor harvest years that caused famine, Yemen was basically self-sufficient in food. Given the lack of modern health care and endemic poverty in many areas, the population was relatively stable throughout the period of the Mutawakkilite Kingdom. Both imams Yahyā and Ahmad limited foreign travel and intervention in Yemen, so the economic system remained stagnant with limited trade. The currency in Yemen was based mainly on the silver Maria Theresa thaler, known as the riya $l$, which weighed about 28 grams. In 1955 it was worth 80 U.S. cents. ${ }^{122}$ The riyāl was divided into smaller units, each known as a buqsha. The units of 2 buqsha and above were in silver and the ones below were copper. Weights and measures relating to agriculture varied in Yemen, depending on the time and location (Table 1).

\begin{tabular}{|c|c|c|c|}
\hline term & weight & location & source \\
\hline uqiyya & $28 \mathrm{gr}$ & & FAO (1960: v) \\
\hline waqiyya & ca. $33 \mathrm{gr}$ & Șan'à' & Rossi (1939: 152) \\
\hline qafla/qifāl, pl. & for precious items & Șan‘à' & Rossi (1939: 152) \\
\hline raṭl/arțāl, pl. & $\begin{array}{l}\text { small = } 17 \text { waqiyya } \\
\text { or ca. } 566 \text { gr; used } \\
\text { for coffee, sugar, } \\
\text { rice, dates, drugs }\end{array}$ & Șan'à' & Rossi (1939: 152) \\
\hline raṭl/arțāl, pl. & $\begin{array}{l}\text { medium = } 20 \text { waqiy. } \\
\text { ya or ca. } 666 \mathrm{gr} \text {; } \\
\text { used for meat and ve- } \\
\text { getables }\end{array}$ & Șan‘à' & Rossi (1939: 152) \\
\hline raṭl/arțāl, pl. & $\begin{array}{l}\text { large = } 24 \text { waqiyya } \\
\text { pr ca. } 799 \text { gr; used } \\
\text { for fruit, oil, butter, } \\
\text { honey, petrol }\end{array}$ & Șan‘à' & Rossi (1939: 152) \\
\hline rațl & 560 gr (20 uqiyya) & & FAO (1960: v) \\
\hline raț & $520 \mathrm{gr}$ & al-Hudayda & Pietravalle (1952: 176) \\
\hline $\begin{array}{l}\text { rațl } \\
\text { ("Yemenite Pound") }\end{array}$ & 16 ounces & Ta'izz & Sharafaddin (1961: 14) \\
\hline uqqa & 1,176 gr (42 uqiyya) & & FAO (1960: v) \\
\hline farāsila/farāsil, pl. & 20 raṭl & Șan'ā', Ta'izz & $\begin{array}{l}\text { Rossi(1939:152), } \\
\text { Sharafaddin (1961: 14) }\end{array}$ \\
\hline farsala & $12.6 \mathrm{~kg}(22.5 \mathrm{ratt})$ & Aden & FAO (1960: v) \\
\hline farsala & $11.2 \mathrm{~kg}(20 \mathrm{ratl})$ & Șan'à' & FAO (1960: v) \\
\hline
\end{tabular}

${ }^{122}$ FAO: (1960: v). 


\begin{tabular}{|l|l|l|l|}
\hline farsala & $11.2 \mathrm{~kg}(18.5 \mathrm{ratl})$ & al-Hudayda & FAO (1960: v) \\
\hline farsala & $10.4 \mathrm{~kg}(20 \mathrm{ratl})$ & al-Ḥudayda & Pietravalle (1952: 176) \\
\hline
\end{tabular}

\section{Weights}

\begin{tabular}{|c|c|c|c|}
\hline term & measure & location & source \\
\hline frāsila & $10.5-11.5 \mathrm{~kg}$ & Wādī Mawr & Escher (1976: xxi) \\
\hline frāsila & $10.5 \mathrm{~kg}$ & al-Hudayda & al-'Aẓm (1986: 85) \\
\hline mudd & perhaps $1.8-2.2 \mathrm{~kg}$ & Jawf & al-‘Azm (1986: 106) \\
\hline nafar & $\begin{array}{l}0.625 \text { liter }(1 / 8 \\
\text { thumn })\end{array}$ & & FAO (1960:v) \\
\hline nafar & $0.9625 \mathrm{lb}$ & Ta'izz & Sharafaddin (1961: 14) \\
\hline nafar/anfār, pl. & 1/64 qadah & Șan'à' & Rossi (1939: 152) \\
\hline qadah & 40 liters & & $\begin{array}{l}\text { FAO (1960: v) } \\
\text { Pietravalle (1952: 176) }\end{array}$ \\
\hline qadaḥ/aqdāh, pl. & $\begin{array}{l}\text { ca. } 36 \text { liters; used for } \\
\text { solid items; divided } \\
\text { into } 64 \text { nafar }\end{array}$ & Șan'à' & Rossi (1939: 152) \\
\hline qadah & $61.6 \mathrm{lb}$ & Ta'izz & Sharafaddin (1961: 14) \\
\hline qadah & $\begin{array}{l}30 \mathrm{~kg} \text { (sorghum) } \\
32 \mathrm{~kg} \text { (millet) } \\
25 \mathrm{~kg} \text { (sesame) }\end{array}$ & Wādī Mawr & Escher (1976 :xxi) \\
\hline thumn & 5 liters (1/8 qadah) & & FAO (1960: v) \\
\hline thumun & 1.8 qadah & Șan'à' & Rossi (1939: 152) \\
\hline mudd & & al-Jawf & \\
\hline
\end{tabular}

Capacity Measures

\begin{tabular}{|c|c|c|c|}
\hline term & measure & location & source \\
\hline$b \bar{a}^{\prime}$ & $\begin{array}{l}\text { ca. } 160 \mathrm{~cm} \text {, two arm } \\
\text { lengths }\end{array}$ & Wādī Mawr & Escher (1976: xxi) \\
\hline dhir $\bar{a}^{`}$ & ell or armlength & Șan'ā; & Rossi (1939: 152) \\
\hline dhirāa & $67 \mathrm{~cm}$ & & FAO (1960: v) \\
\hline dhirā' & $68 \mathrm{~cm}$ & & Pietravalle (1952:176) \\
\hline dhirā' (iron) & $2 / 3$ meter & $\mathrm{Ta} \mathrm{Ta}^{\prime} \mathrm{zzz}$ & Sharafaddin (1961:14) \\
\hline dhirā' (hand) & $1 / 2$ meter & Ta'izz & Sharafaddin (1961:14) \\
\hline faddān & 75 lubna & & al-Wāsi‘̄̄ (1948:86) \\
\hline lubna/libna & $\begin{array}{l}45 \text { sq m (100 square } \\
\left.\text { dhirä } \bar{a}^{\prime}\right)\end{array}$ & & FAO (1960:v) \\
\hline libna & 10 iron ells & & $\begin{array}{l}\text { Rossi (1939:152); al-Wāsi‘̄i } \\
(1948: 86)\end{array}$ \\
\hline
\end{tabular}




\begin{tabular}{|c|c|c|c|}
\hline ma'ad & $\begin{array}{l}4,500 \text { sq m }(100 \\
\text { lubna })\end{array}$ & & FAO (1960: v) \\
\hline ma'ad & $\begin{array}{l}\text { ca. } 4,200 \text { sq m } \\
\left(40 \times 40 b \bar{a}^{`}\right)\end{array}$ & Wādī Mawr & Escher (1976: xxi) \\
\hline$q \bar{a} m a$ & $\begin{array}{l}\text { length of a man } \\
\text { standing }\end{array}$ & Șan'à' & Rossi (1939: 153) \\
\hline shayz/ashyāz, pl. & $\begin{array}{l}\text { "inch," from the tip } \\
\text { of the index finger } \\
\text { extended to the tip of } \\
\text { the thumb }\end{array}$ & Șan'à' & Rossi (1939: 153) \\
\hline shibr & $\begin{array}{l}\text { extended palm of the } \\
\text { hand, from the tip of } \\
\text { the little finger to the } \\
\text { tip of the index }\end{array}$ & Șan‘à' & Rossi (1939: 153) \\
\hline
\end{tabular}

\section{Lineal Measures}

Table 1. Weights and Measures during the Mutawakkilite Kingdom

One of the most visible aspects of agriculture in Yemen's highlands is the system of terraces. As suggested by the traveler G. Wyman Bury, who traveled in Yemen during the late Ottoman era, the highland farmer was ingenious but had to deal with many dangers: ${ }^{123}$

"He has to wrestle with elemental forces that may cover acres of coffee under tons of debris, or skin the surface-soil from his carefully prepared gardens, and dump valuable alluvial deposits beyond the reach of even a baboon.

His only tools are the hoe or mattock, a reed basket, and an empty kerosene tin for carrying water, but these are wielded with skill and infinite perseverance.

It is not too much to say that, in the highlands of central Yamen, every accessible spot where crops will grow has been terraced and tilled for coffee, corn or garden produce. These terraces are faced with stone, and follow the contours of the hill, sometimes enclosing a mere strip some few feet wide, and sometimes an acre or so, according to the profile of the slope. Most of them were built centuries ago, and they are maintained and cultivated by constant toil and vigilance.

Let a mountain-rill but cut its way onto one of these terraced plots from above and, unless noticed and diverted, it may swell, in some sudden storm, to a torrent that will bring an acre or two down with it, into depths beyond the reach of man, or, worse still, deposit the lot onto some other farm. Then the question of ruined crops and ownership of the soil is thrashed out with bitter, and often bloody, feud. Legal procedure, whether Ottoman or Arab, tends to put responsibility where it should be on the owner of the upper farm.

He may be called upon to defray all expenses for clearing his neighbour's land, beside damages to any crop underneath the landslip, and has also the mortification of

\footnotetext{
${ }^{123}$ Bury (1915: 103-104).
} 
having lost a good slice of his own farm.

All these possibilities unite to promote careful and painstaking husbandry, while the large population, and more regular rainfall of the highlands, make such detailed methods practicable and profitable.

Apart from the rainfall, however, the soil of the mountains is not so fertile as that of the lowlands. None of those wild mountain-torrents can be trusted to deposit alluvial silt on terraced ground; they are far too drastic in their action. Therefore, the highland farmer must renew his soil from time to time, carrying it in laborious basketfuls up some mere goat-track, from any deposit he has been lucky enough to find unclaimed. The soil can only be turned over to a limited extent, and a plough can barely reach — still less cultivate - any but the larger and more accessible fields. In the smaller upland plots the soil only lies a foot or two deep, and must be tilled gingerly. The principal highland crops are coffee, barley, bearded wheat, white millet, garden-produce and kât (katha edulis), the leaves and tender shoots of which are much in demand for their exhilarant properties.

Animal manure is stored near most of the villages in large heaps, against the stone field-terraces, and deodorised with light soil. It must be used freely, especially for coffee, and is often carried for miles in open panniers on donkey-back."

Another description of terrace cultivation is provided in a British colonial report: ${ }^{124}$

"The topmost terraces on steep mountain slopes are so narrow as to be cultivated only by hand. On the easier middle slopes the field-terraces are broader and supported by ancient massive stone walls; to these fields the rain-water from bare unterraced slopes is led by an intricate system of channels, often cemented, and descending from terrace to terrace. Still lower, the cultivators rely mainly on controlled flood-water; land bordering Wādīs is carefully terraced and bunded for basin irrigation; flooded torrents are led down between stone-faced walls and deflected by structures of stone and brushwood into furrows which serve the land. Below the mountains the water from the large Wādi systems is deflected to inundate the alluvial plains.

The field-terraces in mountainous districts are erected with great toil, and severe punishments are prescribed for their neglect. Soil is often carried from a distance, though carts and other wheeled vehicles are non-existent. Sloping fields are unknown, low terraces being constructed even when the incline is slight, as on the plateau around San'ā."

During the imamate period there was virtually no modern technology applied in agriculture. Preparation of the land was done with the scratch plow, using animal draught power of oxen, camels or donkeys. ${ }^{125}$ Other hand-held tools included the hoe and a type of shovel-scoop. Flat boards of wood or iron were used to smooth soil after initial plowing and clods of dirt would be beaten

\footnotetext{
${ }^{124}$ Naval Intelligence Division (1946: 477).

${ }^{125}$ For details on the scratch plow in Yemen, see Gingrich and Heiss (1986) and Varisco (1983).
} 
with a club. For some crops, like wheat and barley, the plow might be fitted with a seed funnel; with sorghum the seeds were dropped by hand into the furrow at given spaces. Due to the presence of animals on all farms, manure was applied with no imported fertilisers. Interplanting of legumes with sorghum and millet was practiced, as was crop rotation and the use of fallow. Pruning and harvesting were done with fretted knives. Threshing of wheat and barley was usually done on a stone floor or hard mud surface with a stone or iron board pulled by an animal, while sorghum heads were beaten with flails. The Syrian traveler al-'Azm noted in 1927 that rural women were actively engaged in agricultural activities, such as planting, plowing, marketing produce, collecting and grinding coffee. ${ }^{126}$ Much of what is described in the sources before 1962 could be observed in the late 1970s and in some areas continues through the present day. ${ }^{127}$

A wide variety of crops are recorded as cultivated in the kingdom, most having been a feature of yemeni agriculture for generations (Annex A). The main cereal crop, planted in the spring and harvested in the fall, was sorghum (dhura), both coastal and highland varieties. ${ }^{128}$ Sorghum was valued both for its nutritious grain, which could be made into a porridge ('așīd) or bread, but also was a major source of animal fodder. In his journey through Yemen in 1937-1938, Hugh Scott remarked that in mid-September for the valley of al-Ḍāli“ "almost every cultivable spot was covered with tall green crops of ripening dhura." $129 \mathrm{He}$ describes the sorghum and local agricultural work on Jabal Jihaf at 7100 feet above sea level as follows: ${ }^{130}$

"At the end of September the tribesmen of Jebel Jihaf were busy with dhurra harvest. Gangs of labourers, stripped to the waist, wearing white skirts to the knees and white or indigo-dyed turbans, hand-picked the heads of grain from the tall dhurra plants. All day the countryside resounded with a chorus, haunting and drawn out into quavering notes, sung by the harvesters. Wheat and barley were also reaped and laid out in small bundles on natural threshing-floors of bare rock. Threshing is done with an unjointed flail consisting of a long curved stick, and winnowing by the simple process of holding a petrol tin or other receptacle over the head and pouring the grain and chaff out slowly, so that the chaff is blown away. After the dhurra heads are gathered the stems are grubbed up and piled in conical stacks for fodder and litter. Ploughing with yoked oxen then begins, and the ploughman's womenfolk often follow in his wake, breaking the clods with mattocks. ${ }^{131}$ Water is drawn all through the day for drinking and for the irrigation of beds of young onions and other

\footnotetext{
126 Al-‘Aẓm (1986: 95).

${ }^{127}$ The most detailed study of traditional Yemeni agriculture is by al-'Ansī (1998).

${ }^{128}$ For details on sorghum production in Yemen, see Naval Intelligence Division (1946: 480-482) and Varisco (1985).

${ }^{129}$ Scott (1939: 100). Note that British accounts often refer to dhura as "millet" rather than sorghum, but this should not be confused with $d u k h n$ as the common term for millet.

${ }^{130}$ Scott (1939: 102-103).

${ }^{131}$ On the San ‘à' plain Rossi (1939: 117) observed a team of three men using a heavy iron shovel to shift the soil of the furrows.
} 
crops; a yoke of oxen, descending an inclined plane, hauls up a large leather bucket by a rope passing over a wooden pulley."

The other major cereal grains were wheat and barley, sown as winter crops in the highlands. Maize had been introduced during the Ottoman period. In the coastal region bulrush millet, foxtail millet and teff were cultivated. A variety of vegetables, fruits, herbs and flowers were cultivated. Dates were especially prevalent in the Tihāma, Haḍramawt and Najrān. ${ }^{132}$ Most of these crops, apart from tomatoes and potatoes, had been planted in Yemen for centuries. A perennial problem throughout Yemen's history has been plagues of locusts. It is reported that Imam Yahyā refused anti-locust workers from the Aden Protectorate until 1944. ${ }^{133}$

It is apparent from the texts that there had been an increase in production of qāt (Catha edulis), one of the most important tree crops in Yemen. ${ }^{134}$ In his trip at the turn of the 20th century, al-Barakātī provides a few details. ${ }^{135} \mathrm{He}$ describes the leaves of $q \bar{a} t$ as similar but larger to those of the pomegranate tree. Qāt chewing is accompanied by smoking tobacco and drinking coffee, but he notes that it is not chewed in the 'Asīr region. He does not have a high opinion of $q \bar{a} t$, noting that it can cost up to half a day's wages and reduces hunger, but for no real benefit. ${ }^{136}$ The Syrian traveler al-'Aẓm notes that $q \bar{a} t$ treees, which can reach up to five meters, were grown like those of coffee in upper wādī areas without too much heat. ${ }^{137}$ He adds that $q \bar{a} t$ varieties were primarily known by where they were grown, such as in Ta'izz, Bura' and Raymā. In 1927 the cost of a small bundle (rizma) was expensive, almost three francs. Al-Wāsi`ī suggests that qāt had recently been planted in al-Dilā'.

Most Western travelers were critical of $q \bar{a} t$ chewing. The criticism by Harold Ingrams is poetic: "It must be a very acquired taste, for I have tried a leaf or two and thought it was filthy, but when you have acquired that taste it makes you feel a devil of a dog so long as the feeling lasts." ${ }^{138}$ Hugh Scott, in the 1930s, called it the "bane of this part of Arabia," comparing it to being drunk. ${ }^{139}$ Also writing in the 1930 s, Britton describes its cultivation: ${ }^{140}$

"Each plant is said to produce three crops a year. The sprigs, 6-8 inches in length, of younger leaves are picked and bound into small bundles, which in turn are wrapped for protection in grass. In this way the drug is kept in good condition for about a week, and so can be carried to Aden by camel. In Arabia the tree is cultivated at altitudes between 5000 and 9000 feet, on the mountain terraces. Its optimum conditions

\footnotetext{
132 See Naval Intelligence Division (1946: 486-490) for details on date production in the Arabian Peninsula, including Yemen.

${ }^{133}$ Naval Intelligence Division (1946: 498).

${ }^{134}$ See Naval Intelligence division (1946: 492-493) for details on qāt production in Yemen.

135 Al-Barakātī (1384/1964: 162).

${ }^{136}$ This negative view of $q \bar{a} t$ as a dangerous "drug" is echoed by Tarsīsī (1962: 156-157), noting the difference between $q \bar{a} t$ and coffee is black and white in terms of $q \bar{a} t$ 's negative influence on the economy and health.

${ }^{137}$ Al-'Azm (1986: 69). Ameen Rihani (1930: 35) notes that it is grown between 2,000-7,000 feet and cites Bukhārī as the best variety.

${ }^{138}$ Ingrams (1943: 109-110), who details the taxes imposed by the imam on the qat trade.

${ }^{139}$ Scott (1939: 107).

${ }^{140}$ Britton (1939: 122).
} 
of growth seem to be similar to those of coffee. In the Aden Protectorate the necessary conditions are found only in the mountains near the Yemen frontier; at Dhala (4800 feet) the growth is stunted, the plants being no more than a foot in height, while they appear to attain their maximum growth on the terraces of Jabal Sabir, neat $\mathrm{Ta}$ 'izz in the Yemen, a district where the rainfall is comparatively great."

Officially, only a small amount of $q \bar{a} t$ was said to be grown in the Aden Protectorate, as late as the 1950s, and it was banned in the Aden Colony in 1957. According to Brooke: ${ }^{141}$

"Before October 1949 nearly all the leaf consumed in the Colony was imported from Yemen. Without foreign competition, Yemen had increased its shipments to Aden from 616,988 pounds in 1935 to 2,415,248 pounds in 1949. Ethiopian khat sent by air to Aden gained rapidly consumer preference and a far greater market than was ever reached by the Yemen variety. In a little more than a year after the initial shipment, Ethiopia displaced Yemen as the leading exporter, and the relative position of Yemen in the Aden market thereafter declined... in 1956 the British Colony imported $3,781,344$ pounds of khat valued at $£ 1,890,701$ (U.S. $\$ 5,293,962$ ); of this, only twelve per cent. was the share of imports from Yemen."

Yemen was best known in the early part of the 20th century for its coffee, even though the trade from the Red Sea port of Mocha had long been eclipsed by coffee grown elsewhere. ${ }^{142}$ Coffee was grown mainly in the western escarpment and benefitted from the mists during the monsoon season. There were many varieties of coffee, but one of the best was often said to be from Banī Matar and was generally known as șâfi ${ }^{143}$ The traveler al-'Aẓm, in 1927, described the coffee he saw on his trip from al-Hudayda to Șan' $\bar{a}$ ':

"I observed the coffee tree, which in some respects resembles the lemon tree; its berry is red in color, like coral. When it matures and completely ripens, women take it to their homes and spread it on the roof until it is dry and takes on the color of black. It is ground in hand mills, extracting the black husk (qishra) and with the pure bean $(s \bar{a} f \bar{\imath})$ remaining. The Yemenis only use the qishr for drinking and never use the beans. They say the qishr is soothing and very beneficial to the body. Sometimes they boil it with cardamom $(h \bar{a} l)$ or cinnamon ( $q i r f a)$ in clay coffee pots especially made in Yemen." 144

Western observers of agriculture in the kingdom were impressed by the ingenuity and work ethic of Yemeni farmers, but were also aware that it had become stagnant. Paolo Pietravalle argues that this was due to the autocratic regime of the imams, who kept Yemen isolated from outside influence, including development of agriculture. ${ }^{145} \mathrm{He}$ remarks that future development of Yemeni agriculture was constrained by the limited consumption demands, transport difficulty,

\footnotetext{
${ }^{141}$ Brooke (1960: 55).

${ }^{142}$ For details on Yemeni coffee during the kingdom, see Naval Intelligence Division (1946: 490-492).

${ }^{143}$ Al-'Aẓm (1986: 85), who also mentions coffee from Jabal Bura' and Raymā.

144 Al-'Azmm (1986: 85).

145 Pietravalle (1952: 169-170).
} 
burdensome taxation, long distances for trade, and lack of economic vitality. ${ }^{146}$ Noting that the average Yemeni consumed no more than $120 \mathrm{~kg}$ of sorghum per year, he calculated the annual sum of sorghum consumption at 5 million cubic meters; this was said to be sufficient to feed twice the current population at the time, ca. 1952.

Several writers indicate that the imams were interested in developing the production of cotton, including the import of new varieties. As early as the 1940s it was noted that the import of new varieties of plants and seeds was "leading to wholesale extermination of local varieties almost everywhere except in primitive communities." 147 There was a general impression throughout the first half of the 20th century that Yemen had plenty of water available due to its seasonal floods and groundwater. Only a few pumpwells had been installed before the 1962 revolution. In many areas the groundwater was still accessible in hand-dug wells, but this was to change radically with the influx of tubewells in the 1970s and beyond.

In sum, on the eve of the 1962 revolution, Yemen's agriculture had changed little from previous centuries. The second Ottoman occupation introduced a few new crops and techniques, but the protective mindset of the two imams hindered development in the agricultural sector. Much of the civil war was fought in the areas north of San'a terrace systems and interrupting trade in agricultural produce. The lack of technical education training, as was happening elsewhere in the Arab world at this time, left farmers on their own in battling climate, pests and crop diseases. Development aid poured into Yemen after the civil war ended, but the decline of the traditional system was inevitable.

\footnotetext{
${ }^{146}$ A U.S. Consul report from Aden in 1922 noted that Imam Yahyā was taxing agriculture at a rate of 20\% due to his lack of funds after the Ottomans left (Sinclair 1976(1): 21).

${ }^{147}$ Naval Intelligence Division (1946: 474).
} 


\section{Appendix A. Cultivated Crops of Mutawakkilite Yemen ${ }^{148}$}

\begin{tabular}{|c|c|c|}
\hline Arabic & English & Comments \\
\hline 'adas & lentils & $\begin{array}{l}\text { also called bilsin; term used by } \\
\text { tribesmen Rossi (1939: 165) }\end{array}$ \\
\hline 'alas & emmer wheat & $\begin{array}{l}\text { also called nusūl; best variety for } \\
\text { bread (al-Wāsi'īi 1948: 139) }\end{array}$ \\
\hline ‘amb & mango & $\begin{array}{l}\text { equivalent of manja and 'ambā' in } \\
\text { Egypt; also 'anbā Rossi (1939: 165) }\end{array}$ \\
\hline 'anbarūd & pear & Rossi (1939: 166) \\
\hline ansūn & anise & grown in Ghamdān \\
\hline 'atar & peas & $\begin{array}{l}\text { also julubbān; bisilla in Egypt; } \\
\text { Rossi (1939: 164) }\end{array}$ \\
\hline bābāya or 'amba al-Shām & papaya, pawpaw & \\
\hline bābūnaj & camomile & Rossi (1939: 164) \\
\hline bādhinjān & eggplant, aubergine & $\begin{array}{l}\text { said to be introduced by Ottoman } \\
\text { soldiers in 19th century (Abdul- } \\
\text { fattah 1981: 46); see batlajān }\end{array}$ \\
\hline balas & fig & $\begin{array}{l}\text { alternative term for } \operatorname{tin} ; \text { Rossi } \\
(1939: 164)\end{array}$ \\
\hline balas Turkī/al-Shawkī & Opuntia cactus & called șbayra in Syria \\
\hline bāmiya & okra & $\begin{array}{l}\text { grown in Tihāma; } \\
\text { said to be introduced by Ottoman } \\
\text { soldiers in 19th century (Abdulfat- } \\
\text { tah 1981: 46) }\end{array}$ \\
\hline banafsaj & violet & Rossi (1939: 166) has banafsha \\
\hline banjar & beet & Rossi (1939: 163) \\
\hline baqdanūs & parsley & Rossi (1939: 166) \\
\hline bāqilla ${ }^{\prime}$ & broad bean & $\begin{array}{l}\text { also known as fül; Rossi (1939: } \\
\text { 164); see qilla }\end{array}$ \\
\hline bardaqūsh & marjoram & Rossi (1939: 165) \\
\hline barqūq & apricot & $\begin{array}{l}\text { alternative for mishmish, } \\
\text { in full bloom at end of January and } \\
\text { green fruit by end of February in } \\
\text { San'ā' (Scott 1939: 117); Rossi } \\
\text { (1939: 163) }\end{array}$ \\
\hline
\end{tabular}

${ }^{148}$ This list is compiled from the sources translated and summarised above and also from Naval Intelligence Division (1946), Scott (1939), Sharaf al-Dīn (1964: 22) and other sources. This is not a comprehensive list and many of the crops listed have a long history of cultivation in Yemen. 


\begin{tabular}{|c|c|c|}
\hline baṣal & onion & $\begin{array}{l}\text { grown with irrigation between } \\
7,000-8,000 \text { feet (NDI:473); Rossi } \\
(1939: 164)\end{array}$ \\
\hline bațāțīs/batāạtā & potato and sweet potato & $\begin{array}{l}\text { grown in Aden Protectorate and } \\
\text { elsewhere; Rossi (1939: 165); } \\
\text { introduced into highlands in } 1939 \\
\text { (Keen 1946) }\end{array}$ \\
\hline batlajān & eggplant & Rossi (1939: 165); see bādhinjān \\
\hline bilsin & lentils & $\begin{array}{l}\text { term in towns Rossi (1939: 165); } \\
\text { see 'adas }\end{array}$ \\
\hline birr/burr & wheat & $\begin{array}{l}\text { equivalent of hința and qamh; the } \\
\text { best varieties are al-'Ansī and al- } \\
\text { Bawnī; varieties include samrā', } \\
\text { ah-mar and sawād (al-Wāsi‘'̄ 1948: } \\
\text { 139); limited production in Yemen } \\
\text { (Pietravalle 1952: 166); } \\
\text { Rossi (1939: 165) }\end{array}$ \\
\hline bisbās & chilli pepper & \\
\hline bizāliya & pea & Rossi (1939:166); see 'atar \\
\hline biț̣īkh/batṭīkh & melon varieties & $\begin{array}{l}\text { see habhab, khirbiz and shammām; } \\
\text { yellow variety from Egypt and } \\
\text { Syria called sant and 'ajūr; Rossi } \\
(1939: 165)\end{array}$ \\
\hline bunn & coffee & $\begin{array}{l}\text { grown mostly on the western } \\
\text { escarpment; Rossi (1939: 163) }\end{array}$ \\
\hline burtuqāl & sweet orange & $\begin{array}{l}\text { said to be available in Șan'ā' sūq } \\
\text { year round (Pietravalle 1952: } \\
\text { 167); see al-Wāsi'‘̄ (1947: 130) }\end{array}$ \\
\hline buqūl & legumes & \\
\hline dhura/dhira & sorghum & $\begin{array}{l}\text { many varieties grown all over } \\
\text { Yemen; principle crop of Yemen, } \\
\text { stalks useful as fodder, especially } \\
\text { for camels (Pietravalle 1952: 166); } \\
\text { Rossi (1939: 164) }\end{array}$ \\
\hline al-dhura al-Shāmiya & maize & also called Hind, Rūmī, Shām \\
\hline dijra/dujra & $\begin{array}{l}\text { cowpea } \\
\text { Vigna unguiculata } \\
\end{array}$ & also known as $l \bar{u} b i y \bar{a}{ }^{\prime}$ \\
\hline$d u b b a$ & gourd & Rossi (1939: 166); see qar' \\
\hline dukhn & $\begin{array}{l}\text { bulrush millet } \\
\text { Pennisetum glaucum }\end{array}$ & grown in Tihāma; Rossi (1939: 165) \\
\hline
\end{tabular}




\begin{tabular}{|c|c|c|}
\hline fāṣūliyyā & green bean & Rossi (1939: 164) \\
\hline firsik & peach & $\begin{array}{l}\text { Rossi (1939: 166); see khawkh; cal- } \\
\text { led injās outside Yemen }\end{array}$ \\
\hline fijl & white radish & $\begin{array}{l}\text { also called qushmī in Yemen (al- } \\
\text { Wāsi‘'i 1947: 131) }\end{array}$ \\
\hline$f \bar{u} l$ & broad bean & also known as bāqillā' or qilla/qilla \\
\hline al-fulful al-aswad & black pepper & said to be not of good quality \\
\hline full/fill & Arabian jasmine & grown in Tihāma; Rossi (1939: 165) \\
\hline fuwwa & madder & \\
\hline gharib & $\begin{array}{l}\text { broomcorn millet } \\
\text { Panicum miliaceum }\end{array}$ & \\
\hline habḥab & watermelon & $\begin{array}{l}\text { called bițtikh } \text { outside Yemen; } \\
\text { Rossi (1939: 164) }\end{array}$ \\
\hline handal & colocynth & Rossi (1939: 164) \\
\hline hilba & fenugreek & Rossi (1939: 166) \\
\hline himmis & chick pea & \\
\hline Hind & maize & also called $R \bar{u} m \bar{\imath}, S h \bar{a} m$ \\
\hline hinnā' & henna & \\
\hline hinta & wheat & see birr/burr \\
\hline$h u b \bar{u} b$ & cereal grains & $\begin{array}{l}\text { includes wheat, barley, sorghum, } \\
\text { millet, sesame, etc. }\end{array}$ \\
\hline humar & tamarind & \\
\hline ijjāạs & plum & $\begin{array}{l}\text { grown in highlands; Rossi (1939: } \\
\text { 166) has } n j \bar{a} s \underline{\text {. }}\end{array}$ \\
\hline 'inab & grapes & $\begin{array}{l}\text { grown mostly in the highlands; } \\
\text { Rossi (1939: 166) has 'anab }\end{array}$ \\
\hline jawāfa & guava & grown in Lahj \\
\hline jawz & walnut & $\begin{array}{l}\text { grown in highlands; Rossi (1939: } \\
\text { 165) }\end{array}$ \\
\hline jawz al-Hind & coconut & grown in Lahj \\
\hline jazar & carrots & Rossi (1939: 164) \\
\hline juljulān/jiljilān & sesame & $\begin{array}{l}\text { Tihāma term for simsim } \\
\text { al-‘Aẓm (1986: 51); Rossi (1939: } \\
\text { 66) }\end{array}$ \\
\hline kabbād & citron & \\
\hline kabzara & coriander & Rossi (1939: 164) \\
\hline$k \bar{a} d h \bar{\imath}$ & screwpine & grown in the Tihāma \\
\hline kammūn & cummin & grown in Ghamdān \\
\hline karräth & chinese chive & Rossi (1939: 166) has karat \\
\hline
\end{tabular}




\begin{tabular}{|c|c|c|}
\hline khadrawāt & vegetables & \\
\hline khardal & mustard & $\begin{array}{l}\text { grown in Ta'izz (NDI:473); also } \\
\text { known as tartar; pressed for oil; } \\
\text { Rossi (1939: 166) }\end{array}$ \\
\hline khashkhāsh & poppy & \\
\hline khass & lettuce & \\
\hline khawkh & peach & $\begin{array}{l}\text { equivalent of firsik; called } i j j \bar{a} s \\
\text { outside Yemen }\end{array}$ \\
\hline khirbiz & melon variety & \\
\hline khirmish & custard apple & $\begin{array}{l}\text { Lahj and Hudayda, called qishța in } \\
\text { Egypt }\end{array}$ \\
\hline khiyāar & cucumber & Rossi (1939: 164) \\
\hline khubbayza & mallow & Rossi (1939: 165) \\
\hline khuzāma & lavender & equivalent of raymān \\
\hline kinib & $\begin{array}{l}\text { foxtail millet } \\
\text { Setaria italica }\end{array}$ & \\
\hline kishd & hyacinth bean & \\
\hline kittān & flax & Rossi (1939: 165) \\
\hline kumathra & pear & equivalent of 'anbarūd \\
\hline lahāna & cabbage & $\begin{array}{l}\text { grown in Hadramawt; equivalent } \\
\text { of kurunb; said to be introduced by } \\
\text { Ottoman soldiers in 19th century } \\
\text { (Abdulfattah 1981:46); Rossi } \\
\text { (1939: 164) }\end{array}$ \\
\hline lawz & almond & $\begin{array}{l}\text { halhal in the shell; Rossi (1939: } \\
\text { 165) }\end{array}$ \\
\hline $\lim \bar{u} n$ & lemon & sweet and sour varieties \\
\hline lübiyā' & cowpea & \\
\hline marzanjūsh & marjoram & \\
\hline mawz & banana & Rossi (1939: 163) \\
\hline mishmish & apricot & alternate for $b a r q \bar{u} q$ \\
\hline muddār & sugar care & Yemeni term for qașab al-sukkar \\
\hline mūma & cotton seed & \\
\hline narjis & narcissus & \\
\hline nakhl/nakhīl & date palm & $\begin{array}{l}\text { grown in Tihāma, Haḍramawt and } \\
\text { Najrān; Rossi (1939: 165) }\end{array}$ \\
\hline$n a^{\prime} n a^{\prime}$ or $n a^{\prime} n \bar{a}$ ' & mint & Rossi (1939: 165); see $n u^{\prime} d$ \\
\hline$n \bar{\imath} l$ & indigo & grown in Tihama and Haḍramawt \\
\hline
\end{tabular}




\begin{tabular}{|c|c|c|}
\hline$n u^{\prime} d$ & $\operatorname{mint}$ & Rossi (1939: 165); see na'na' \\
\hline nusūl & emmer wheat & also called 'alas \\
\hline$q a d b$ & lucerne or alfalfa & $\begin{array}{l}\text { also called birsim; Rossi (1939: } \\
\text { 164) }\end{array}$ \\
\hline qar" & gourd & Rossi (1939: 166); see dubba \\
\hline qașab al-sukkar & sugarcane & $\begin{array}{l}\text { also known as muddāar; Rossi } \\
(1939: 164)\end{array}$ \\
\hline$q \bar{a} t$ & Catha edulis & $\begin{array}{l}\text { grown in highlands; internal trade } \\
\text { worth } 1.5 \text { million thalers per day } \\
\text { (Pietravalle 1952: 168); Rossi } \\
(1939: 165)\end{array}$ \\
\hline qilla & broad bean & Rossi (1939: 164); see bāqillā' \\
\hline qiththā' & snake cucumber & called qatt outside Yemen \\
\hline qurunfil & carnation & Rossi (1939: 165) \\
\hline quhțta & Nigella or black cumin & $\begin{array}{l}\text { equivalent of al-habba al-sawdā' } \\
\text { and shawnīz in Egypt and Syria }\end{array}$ \\
\hline qushmī & long white radish & Rossi (1939: 166) \\
\hline$q u t ̣ n$ & cotton & $\begin{array}{l}\text { also called ' } u t b ; \text {; cotton seed is } \\
m \bar{m} m a\end{array}$ \\
\hline rayhạn & basil & Rossi (1939: 163) \\
\hline raymān & lavender & equivalent of khuzāma \\
\hline rizz & rice & Rossi (1939: 166) \\
\hline$R \bar{u} m \bar{\imath}$ & maize & $\begin{array}{l}\text { also called Hind, Shām; Rossi } \\
(1939: 165)\end{array}$ \\
\hline rummān & pomegranate & $\begin{array}{l}\text { in bloom in early March in Șan'ā' } \\
\text { (Scott 1939:117); Rossi (1939: 165) }\end{array}$ \\
\hline rutab & ripe dates & see $n a k h l / n a k h \bar{l} l$ \\
\hline safarjal/sfarjal & quince & $\begin{array}{l}\text { in bloom in early March in San'a }{ }^{\prime} \\
\text { (Scott 1939: 117); Rossi (1939: 164) }\end{array}$ \\
\hline samrā' & wheat variety & \\
\hline saqla & barley variety & $\begin{array}{l}\text { white and thinner than ordinary } \\
\text { barley (al-Wāsi'î 1948: 139) }\end{array}$ \\
\hline sa'tar & thyme & Rossi (1939: 166) \\
\hline sbānak & spinach & Rossi (1939: 166) \\
\hline shadhāb & rue & Rossi (1939: 166) \\
\hline shāh al-turunj & fumitory & Also known as al-bādhrinjūwìya \\
\hline sha'īr & barley & Rossi (1939: 165) \\
\hline Shām & maize & also called Hind, Rūmī; Rossi \\
\hline
\end{tabular}




\begin{tabular}{|c|c|c|}
\hline & & $(1939: 165)$ \\
\hline shamār & fennel & $\begin{array}{l}\text { grown in Ghamdān; Rossi (1939: } \\
\text { 164) }\end{array}$ \\
\hline shammām & cantaloupe & $\begin{array}{l}\text { only grown in palace gardens (al- } \\
\left.\text { Wāsi }{ }^{\top} \overline{1}\right)\end{array}$ \\
\hline shibith & dill & see $z u q \bar{q} q a$ \\
\hline shilik & strawberry & $\begin{array}{l}\text { derived from Turkish, rare Rossi } \\
\text { (1939: 164) }\end{array}$ \\
\hline simsim & sesame & $\begin{array}{l}\text { also known as juljulān; grown in } \\
\text { Tihāma }\end{array}$ \\
\hline tahaf & teff & \\
\hline țamāṭ̂̄sstțamāṭim & tomatoes & $\begin{array}{l}\text { said to be introduced by Ottoman } \\
\text { soldiers in 19th century (Abdul- } \\
\text { fattah 1981: 46); Rossi (1939: 166) }\end{array}$ \\
\hline thūm & garlic & Rossi (1939: 163) \\
\hline $\operatorname{tin}$ & fig & widespread in the highlands \\
\hline $\operatorname{tranj}$ & citron & Rossi (1939:164) \\
\hline tuffāh & apple & rare; Rossi (1939: 165) \\
\hline$t \bar{u} t$ & mulberry & \\
\hline tutun & tobacco & $\begin{array}{l}\text { equivalent of tibgh/tibagh and } \\
\text { tunbāk; grown in Tihāma and } \\
\text { Hadramawt; grown in limited } \\
\text { quantities (Pietravalle 1952: 168) }\end{array}$ \\
\hline usfur & safflower & \\
\hline 'utb & cotton & also called qutn; Rossi (1939: 164) \\
\hline utrujj & citron & also known as kabbād; see țranj \\
\hline ward & rose & Rossi (1939: 166) \\
\hline wars & pseudo saffron & also known as hadas and $\bar{a} s$ \\
\hline$y \bar{a} \operatorname{samin}$ & jasmine & see full; grown in Tihāma \\
\hline yūsufì & tangerine & \\
\hline zinjibül & ginger & in Rayma, Hufāsh, Lā'a \\
\hline zuqīqa & dill & Yemeni term for shibith \\
\hline
\end{tabular}




\section{Bibliography}

Abdulfattah, Kamal. 1981. Mountain Farmer and Fellah in 'Asīr Southwest Saudi Arabia. The Conditions of Agriculture in a Traditional Society. Erlangen: Erlangen Geographischen Arbeiten, Sonderband 12.

al-Akwa', Ismā‘̄îl ibn 'Alī. 1985. al-Amthāl al-Yamāniyya. Șan'ā’': Maktaba al-J̄̄l al-Jadīd.

al-Akwa', Muḥammad ibn 'Alī. 1979. Șahfat min ta'rīkh al-Yemen al-ijtimā'ì wa-qișṣat hayātī. Damascus: Maṭba'at al-Kātib al-'Arab̄i.

al-'Anșī, Yahyā ibn Yahyā. 1998. al-Ma'ālim al-zirā'īya fì al-Yaman. Șan'ā’: al-Markaz alFransī li-al-Dirāsāt al-Yamaniyya and al-Ma'had al-Amrīkī li-al-Dirāsāt al-Yamanīya.

al-'Arshī, Ḥusayn ibn Aḥmad. 1939. Bulūgh al-marām fì sharh misk al-khitām. Edited by Anastase-Marie de St-Elie. Cairo: Maktaba al-Thaqāfa al-Dīnīya.

'Aslān, 'Abd al-Wahhāb Muhammad. 2000. Ghuyūl Șan'à': Dirāsa ta'rīkhīya, atharīya wathā' qūyā. Beirut: Dār al-Fikr al-Ma‘āṣir.

al-‘Aẓm, Nazīh Mu'ayyid. 1986. Riḥla fì bilād al- 'Arabiyya al-Sa'ūdiyya. Second Edition. Cairo: Sharikat Dār al-Tanwīr li-al-Tibā'a wa-al-Nashr. [Original, 1927]

al-Barakātī, Sharaf ibn al-Muhsin.1384/1964. al-Riḥla al-Yamānīya. Beirut: Manshūrāt al-Maktab al-Islāmī.

Britton, Everard B. 1939. Appendix 1: The Use of Qat. Geographical Journal 93(2): 121-122.

Brooke, Clarke. 1960. Khat (Catha Edulis): Its Production and Trade in the Middle East. The Geographical Journal 126(1): 52-59.

Bury, G. Wyman. 1915. Arabia Infelix or The Turks in Yamen. London: MacMillan and Company.

Dostal, Walter. 1993. Ethnographica Jemenija: Auszüge aus den Tagebüchern Eduard Glasers mit einem Kommentar versehen. Sitzungsberichte der philosophisch-historischen Klasse, Band 593, Veröffentlichungen der Arabischen Kommission, Band 5.

Dresch, Paul. 2000. A History of Modern Yemen. Cambridge: Cambridge University Press.

FAO 1960 Report of the FAO Mission to Yemen. Rome: FAO.

Forbes, Rosita. 1923. A Visit to the Idrisi Territory in 'Asir and Yemen. The Geographical Journal 62(4): 271-278.

Gingrich, Andre and Johann Heiss. 1986. A Note on Traditional Agricultural Tools in Sa'dah Province (with Special Reference to the Ard). Proceedings of the Seminar for Arabian Studies 16: 51-63.

Glaser, Eduard. 1884. Meine Reise durch Arḥab und Hâshid. Petermanns Geographische Mitteilungen 30: 174-183, 204-213.

Goitein, Shelomo Dov. 1934. Jemenica: Sprichwörter und Redensarten aus Zentral-Jemen. Leipzig: Harrassowitz.

Grohmann, Adolf. 1922. Südarabien als Wirtschaftsgebiet. Volume 1. Vienna: Verlag des Forschungsinstitutes für Osten und Orient.

al-Hamdānī, al-Ḥasan ibn Aḥmad. 1884. Sifat jazīrat al- 'Arab. Leiden: Brill.

Harrower, Michael J. 2016. Water Histories and Spatial Archaeology: Ancient Yemen and the American West. Cambridge: Cambridge University Press. 
Hartley, Brian J. 1944. Dry Farming Methods in the Aden Protectorate. Proceedings of the Conference on Middle East Agriculture. Agricultural Report No. 6: 37-45.

Ibn Miftāh, Abū al-Ḥasan 'Abd Allāh. 1357/1938. Sharh al-azhar al-muntaz' min al-ghayth almidrār al-mafātih li-kamā'im al-azhār fì fiqh al-a'imma al-ațhār. Cairo: Maṭba'at al-Hijāzī.

Ingrams, Harold. 1943. Arabia and the Isles. London: John Murray.

- 1936. A Report on the Social, Economic and Political Condition of the Hadramawt. London: H.M. Stationary Office, Colonial Report \#123.

al-Iryānī, Muṭahhar. 1471/1996. al-Mu 'jam al-Yamanī fi al-lugha wa-al-turath. Damascus.

Jacob, Harold. 1932. The Kingdom of the Yemen: Its Place in the Comity of Nations. Transactions of the Grotius Society 18:131-153.

Lambardi, Nello. 1950. Yemen: agricoltura e pastorizia sfruttamento del regno animale e vegetale, denominazione arabe locali. Rivista di Agricoltura Subtropicale e Tropicale 44(1-3): 2446.

- 1947. Divisioni Amministrative del Yemen con Notizie Economiche e Demografiche. Oriente Moderno 27(7/9): 143-162.

Keen, B. A. 1946. The Agricultural Development of the Middle East. London: H.H. Stationary Office.

Manzoni, Renzo. 1884. El Yèmen: Tre anni nell'Arabia felice. Rome.

al-Mar'ashalī, Yūsuf. 1427/2006. Nathr al-jawāhir wa-al-durur fì 'ulamā' al-qarn al-rābi' 'ashar. Beirut: Dār al-Ma'rifa.

Maraqten, Mohammed. 2017. Typology of Irrigation Systems in Ancient Yemen in the Light of the Epigraphic Evidence. In Walid Yasin Al Tikriti and Paul Alan Yule, editors, Proceedings of Water \& Life in Arabia Conference, 115-135. Abu Dhabi: Abu Dhabi Tourism and Culture Authority.

Millingen, Charles. 1874. Notes of a Journey in Yemen. Journal of the Royal Geographical Society 44: 118-125.

Mortel, Richard T. 1990. Weights and measures in Mecca during the late Ayyūbid and Mamlūk periods. Arabian Studies 9: 177-85.

Naval Intelligence Division. 1946. Western Arabia and the Red Sea. London: Naval Intelligence Division.

Pietravalle, Paolo. 1952. L'Economia de i lavori pubblici nel Yemen d'oggi. Oriente Moderno 32(7/8): 165-189.

Rihani, Ameen. 1930. Arabian Peak and Desert: Travels in Al-Yaman. London: Constable \& Co.

Rossi, Ettore. 1953. Note sull'irrigazione, l'agricoltura e le stagioni nel Yemen. Oriento Moderno 33(8-9): 349-361.

- 1940a. Un libro di Nazīh el-Mu'ayyad el-'Aẓm sui suoi viaggi nel Yemen e una escursione a Ma’rib nel gennaio-febbraio 1936. Orient Moderno 20(9): 452-458.

- 1940b. Vocaboli sud-arabici nelle odierne parlate arabe del Yemen. Rivista degli Studi Orientali 18: 299-314.

- 1939. L'Arabo Parlato a San 'à'. Rome: Instituto per l'Oriente.

Ruiz, Aldemo. 1966. Efforts of US Agency for International Development to Supply Water to People of Yemen. Journal American Water Works Association 58(10): 1247-1259. 
Scott, Hugh. 1939. A Journey to the Yemen. Geographical Journal 93(2): 97-122.

Serjeant, R. B. 1964. Some irrigation systems in Hadramawt. Bulletin of the School of Oriental and African Studies 27: 33-76.

- 1954. Star-Calendars and an Almanac from South-West Arabia. Anthropos 49(3/4):433-459.

Serjeant. R. B. and Ronald Lewcock (eds.). 2013. Șan ' $\bar{a}$ ': An Arabian Islamic City. UK: Melisende UK Ltd. The original was published in 1983.

Sharafaddin, Ahmad Hossin. 1961. Yemen: “Arabia Felix”. Taiz.

Sharaf al-Dīn, Aḥmad Ḥusayn. 1964. al-Yaman 'abr al-ta'rīkh. Second Edition. 'Ābadīn: Maktabat al-Sunna al-Muhammadīya.

Sinclair, Reginald W. (ed.). 1976. Documents on the History of Southwest Arabia: Tribal Warfare and Foreign Policy in Yemen, Aden and Adjacent Tribal Kingdoms, 1920-1929. Salisbury, NC: Documentary Publications.

Tarsīsī, 'Adnān. 1962. al-Yaman wa-ḥaḍārat al-'Arab ma'a dirāsa jughāfì̀a kāmila. Beirut: Manshūrāt Dār Maktabat al-Ḥayāt.

Thesiger, Wilfred. 1947. A Journey through the Tihama, the 'Asīr and the Hijaz Mountains. The Geographical Journal 110(4/6): 188-200.

Varisco, Daniel Martin. 2004. Terminology for Plough Cultivation in Yemeni Arabic. Journal of Semitic Studies 49(1): 71-129.

- 1994. Medieval Agriculture and Islamic Science: The Almanac of a Yemeni Sultan. Seattle: University of Washington Press.

- 1993. The Agricultural Marker Stars in Yemeni Folklore. Asian Folklore Studies 52(1): 119142.

- 1985. The Production of Sorghum (Dhurah) in Highland Yemen. Arabian Studies 7: 53-88.

— 1983. The Ard in Highland Yemeni Agriculture. Tools and Tillage 4: 158-172.

al-Wāsi'ī, 'Abd al-Wāsi' ibn Yahyā. 1948/1927. Ta'rīkh al-Yaman. Cairo: al-Maṭba 'a Ḥijāzī.

al-Wāsi'‘̄, Ilhām 'Abd Allāh. 2013. Tarjama al-mu'alif al-Durr al-farīd al-jāmi' al-mutafarriqāt al-asānìd.

Electronic document: http://www.ahlalhdeeth.com/vb/showthread.php?t=321329

(Accessed October, 2017).

al-Waysī, Husayn ibn 'Alī. 1962. al-Yaman al-kubrā. Cairo: Maṭa'at al-Nahḍa al-'Arabīya.

al-Zabīdī, Muḥammad b. al-Murtạ̣ā. 1965. Tāj al-'arūs min jawāhir al-qāmūs. Kuwait. 